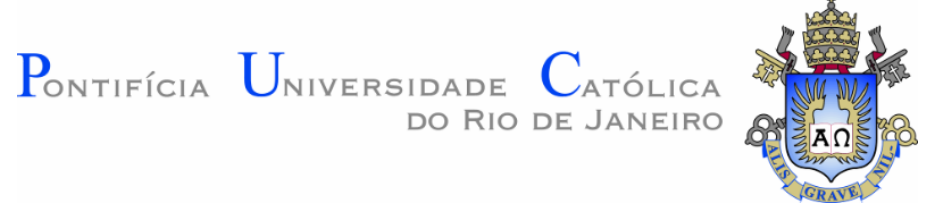

Bruno Farias Mendes

Pornografia on-line: uma nova forma de consumo compulsivo

Tese de Doutorado

Tese apresentada como requisito parcial para obtenção do grau de Doutor pelo Programa de Pós-graduação em Administração de Empresas do Departamento de Administração da PUC-Rio

Orientador: Prof. Luís Fernando Hor-meyll Álvares 


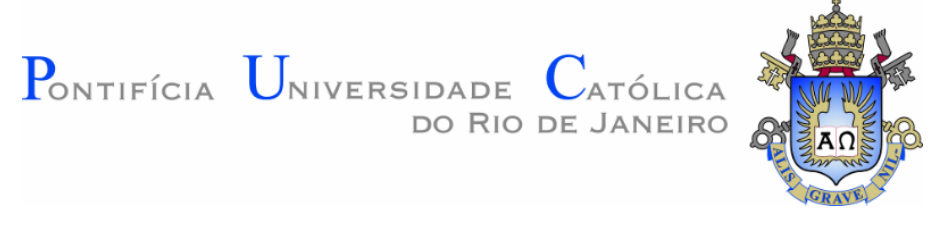

Bruno Farias Mendes

\title{
Pornografia on-line: uma nova forma de consumo compulsivo
}

Tese apresentada como requisito parcial para obtenção do grau de Doutor pelo Programa de Pós-Graduação em Administração de Empresas da PUC-Rio. Aprovada pela Comissão Examinadora abaixo.

\author{
Prof. Luís Fernando Hor-Meyll Álvares \\ Orientador \\ PUC-Rio \\ Prof. Angela Maria Cavalcanti da Rocha \\ PUC-Rio \\ Prof. Breno Sanvicente \\ PUC-Rio
}

Profa. Ana Raquel Coelho Rocha

UFRJ

Prof. Jose Mauro Goncalves Nunes

UERJ

Prof. João Felipe Rammelt Sauerbronn

UNIGRANRIO

Rio de Janeiro, 15 de maio de 2020 
Todos os direitos reservados. É proibida a reprodução total ou parcial do trabalho sem a autorização da universidade, da autora e do orientador

\section{Bruno Farias Mendes}

Graduou-se em Administração na Universidade Cândido Mendes em 2011. Terminou mestrado em Administração na FGV/EBAPE (Fundação Getúlio Vargas) em 2013 e Especialização em Empreendedorismo pela École Supérieure de Commerce de Paris (2013).

Ficha Catalográfica

Mendes, Bruno Farias

Pornografia on-line : uma nova forma de consumo compulsivo / Bruno Farias Mendes ; orientador: Luís Fernando Hor-Meyll Álvares. 2020.

140 f. ; $30 \mathrm{~cm}$

Tese (doutorado)-Pontifícia Universidade Católica do Rio de Janeiro, Departamento de Administração, 2020.

Inclui bibliografia

1. Administração - Teses. 2. Consumo compulsivo. 3. Pornografia on-line. 4. Consumo de pornografia. 5. Disfunção sexual. 6. Autoestima. I. Álvares, Luís Fernando Hor-Meyll. II. Pontifícia Universidade Católica do Rio de Janeiro. Departamento de Administração. III. Título.

CDD: 658 
Em memória dos avós Alzira e Alberto. Meus pais, esposa, filhas, irmão e primo. Ao Centro Dom Bosco, minha segunda família. A Deus e Sua Santa Igreja sobre todas as coisas! † 


\section{Agradecimentos}

À PUC-Rio, pelos auxílios concedidos, sem os quais este trabalho não poderia ter sido realizado.

O presente trabalho foi realizado com apoio da Coordenação de Aperfeiçoamento de Pessoal de Nível Superior - Brasil (CAPES) - Código de Financiamento 001.

Ao Cardeal Orani João Tempesta pelo apoio, estímulo e amizade.

Ao professor Luís Hor-Meyll por ter acolhido o tema da tese e pela orientação, paciência e ensinamentos em toda trajetória. A professora Ângela da Rocha, pelo carinho e atenção que sempre demonstrou desde início.

Aos membros e amigos do Centro Dom Bosco por suportar esta empreitada e manifestarem apoio desde princípio, especialmente nos momentos mais difíceis.

Ao Dom Justino de Almeida Bueno, ao professor Antônio Donato, às freiras carmelitas do Rio de Janeiro, em especial madre Fabiana Maria de Jesus, e ao meu diretor espiritual padre Rômulo Argento por me guiarem no único caminho que importa: o da vida eterna.

No final do célebre livro O Castelo Interior de Santa Teresa D'Ávila, a doutora da Igreja encerra a obra assim: "Se houver algum erro, será por falta de ciência de minha parte. Em tudo me sujeito ao que professa a santa Igreja Católica Romana, em cuja fé vivo, afirmo viver e prometo viver e morrer. Seja Deus, Nosso Senhor, para sempre louvado e bendito. Amém, amém". Faço das palavras da Santa que deu nome a minha primogênita, as minhas.

Viva Nossa Senhora, Rainha!

Viva Cristo, Rei! 


\section{Resumo}

Mendes, Bruno Farias; Alvares, Luís Fernando Hor-Meyll. Pornografia on-line: uma nova forma de consumo compulsivo. Rio de Janeiro, 2020. 141p. Tese de Doutorado - Departamento de Administração, Pontifícia Universidade Católica do Rio de Janeiro.

Hirschman (1992) lançou bases para uma teoria de consumo compulsivo, a partir de estudo conduzido com consumidores de drogas, de álcool e de jogos de azar. O surgimento da Internet trouxe nova forma de consumo compulsivo, a pornografia on-line, com diferenças significativas dos estudados por Hirschman. Uma vez que pouco se conhece sobre o assunto, buscou-se ampliar o conhecimento sobre consumo compulsivo identificando antecedentes e consequências, a partir de relatos de participantes de um grupo brasileiro de suporte on-line que se autodeclaram dependentes. Baseada em interpretação hermenêutica, foi feita netnografia em 9 mil mensagens e discussões em 20 diários de membros da comunidade. Foram identificados seis grupos de antecedentes (percepção de risco, emoções negativas, compulsão em série, mudança relevante de vida e fácil acesso ao consumo) e consequências (percepção da compulsão, objetificação da mulher, queda da autoestima, problemas pessoais e profissionais, depressão e pensamento suicida e disturbios sexuais). Em seguida, foram conduzidas 15 entrevistas com participantes voluntários, para aprofundar o entendimento sobre categorias levantadas. Os resultados revelam que, embora os sete temas identificados por Hirschman estejam presentes nos relatos, outros temas, como objetificação da mulher, perda do senso de masculinidade e distúrbios sexuais parecem ser próprios do consumo de pornografia.

\section{Palavras-chave}

Consumo compulsivo; pornografia on-line; consumo de pornografia; disfunção sexual; autoestima. 


\section{Abstract}

Mendes, Bruno Farias; Alvares, Luís Fernando Hor-Meyll (Advisor). Cyber-porn: a new way of consumption. Rio de Janeiro, 2020. 141p. Tese de Doutorado - Departamento de Administração, Pontifícia Universidade Católica do Rio de Janeiro.

Hirschman (1992) opened the way for a compulsive consumption theory from the study conducted with drugs, alcohol and gambling-addicted. The emergence of the Internet brought with it a new form of compulsive consumption: the online pornography and its peculiarities in relation to Hirschman's study. Since little is known from the subject, we sought to magnify the knowledge on compulsive consumption by the identification of a Brazilian group of online support for auto declared dependents. Based on hermeneutical interpretation, it was made netnography with nine thousand messages and discussions on 20 diaries of members of the community. There were identified six groups of precedents (risk perception, negative emotions, simultaneous addiction, role transition, easy access of consumption) and consequences (perceived addiction, woman objectification, low self-esteem, personal and professional problems, depression and suicidal thought and sexual disorders). Next, fifteen phenomenological interviews were conducted with voluntary participants to deepen the understanding of the identified categories. The results reveal that besides the seven themes pointed by Hirschman that were present on the reports, other themes, such as women objectification, loss of sense of masculinity and sexual disturbances seem to be intrinsic to pornography consumption.

\section{Keywords}

Compulsive consumption; online pornography; pornography consumption; erectile disfunction; self-esteem. 


\section{SUMÁRIO}

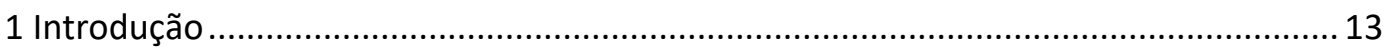

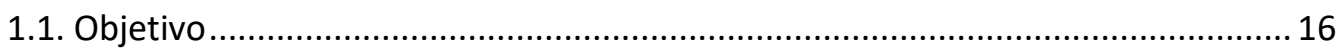

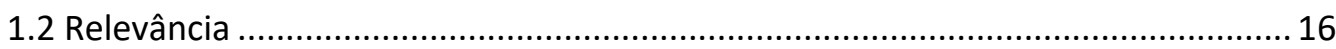

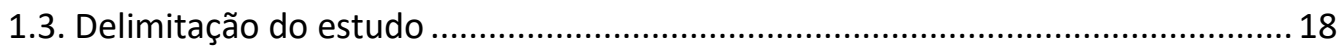

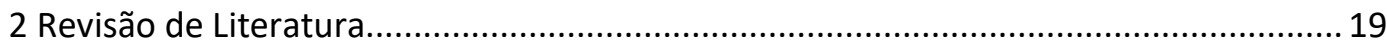

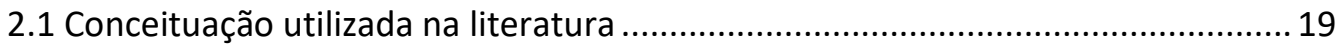

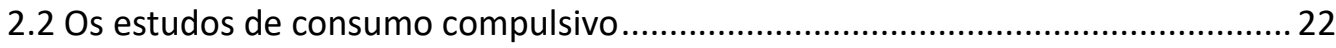

$2.3 \mathrm{Em}$ direção a uma teoria geral de consumo compulsivo ....................................... 28

2.4 Consumo compulsivo de pornografia on-line ........................................................ 32

$2.5 \mathrm{O}$ perfil do consumidor compulsivo de pornografia on-line ................................. 34

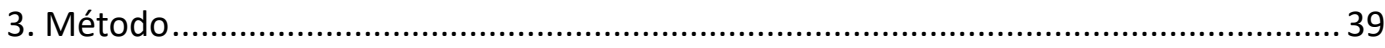

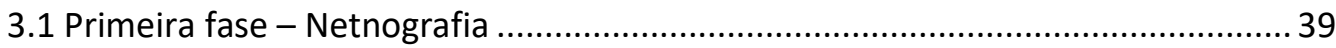

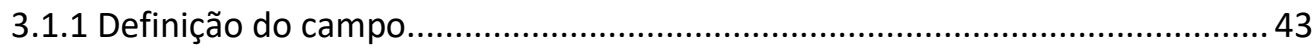

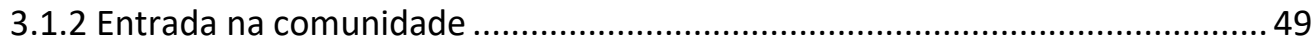

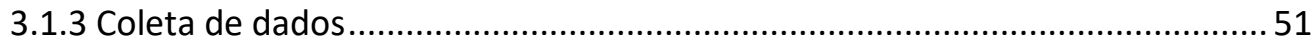

3.1.4 Análise, interpretação e reinterpretação dos dados ……………………….... 55

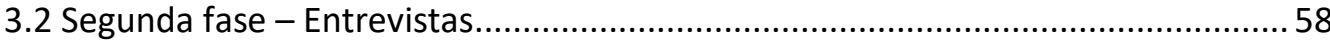

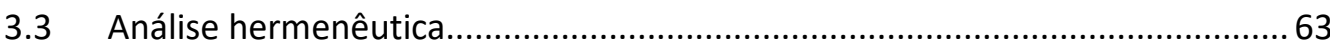

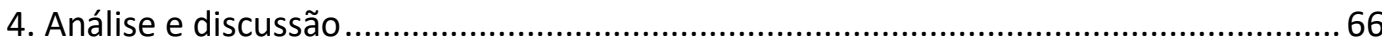

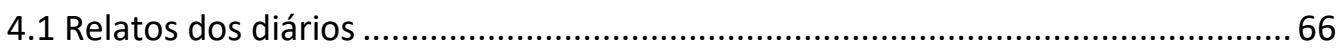

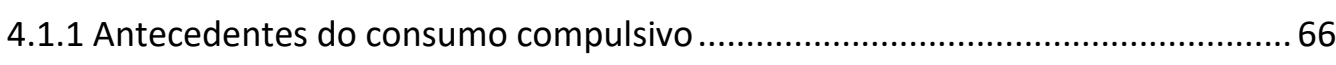

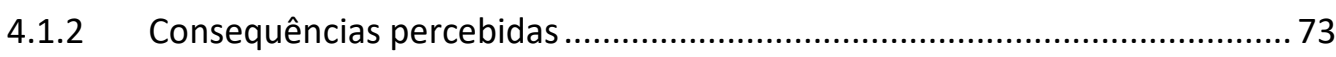

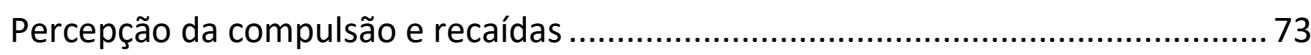

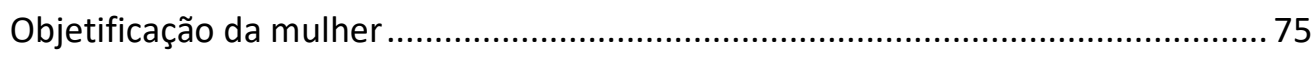

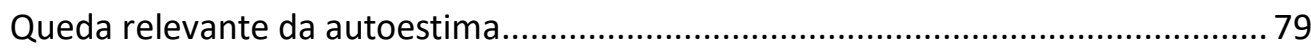

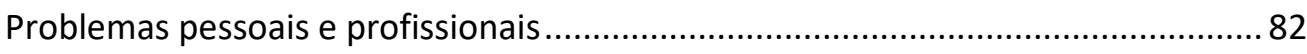

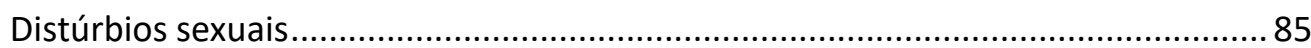

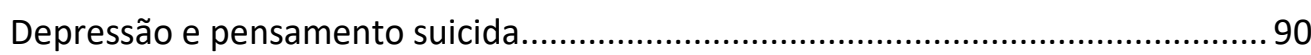

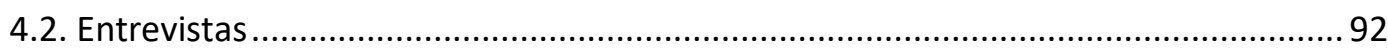

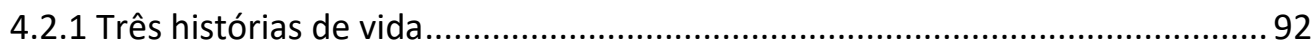

4.2.2 Categorias comuns a teoria geral de consumo compulsivo............................97

4.2.3 Categorias emergentes ............................................................................ 105

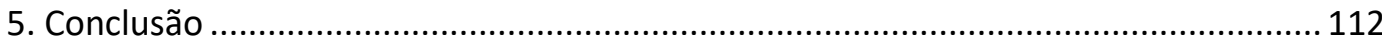

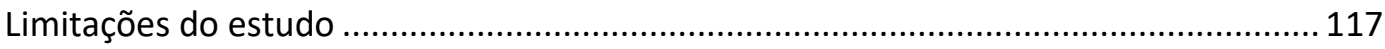




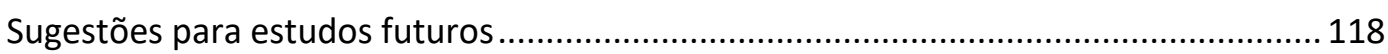

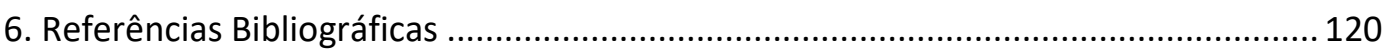

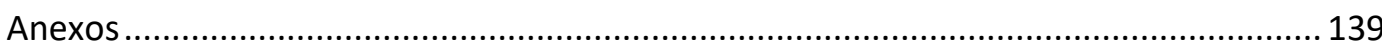




\section{Lista de Quadros}

Quadro 1 - Proposições de Hirschman (1992) e teorias associadas

Quadro 2 - As cinco etapas para aplicação da netnografia

38

Quadro 3 - Lista de diários, separados por faixa etária (dez/ 2019)

Quadro 4 - Status de cada participante do fórum

Quadro 5 - Perfil dos entrevistados e temas recorrentes

Quadro 6 - Categorias com a bibliografia respectiva 


\section{Lista de Figura}

Figura 1 - A Fusão de Horizontes 


\section{1}

\section{Introdução}

Os primeiros estudos sobre aspectos negativos do comportamento do consumidor, como o consumo compulsivo, começaram a surgir em periódicos de marketing em meados da década de 1980 (ROOK; HOCH, 1985; ROOK, 1987; FABER et al., 1987; O'GUINN; FABER, 1987; VALENCE et al., 1988) e se desenvolveram até hoje, principalmente sobre compra compulsiva (GROUGIOU et al., 2009; JOHNSON; ATTMANN, 2009; MOSCHIS, 2017).

Faber e colegas $(1987 ; 1989)$, por exemplo, investigaram o comportamento da compra compulsiva e identificaram que tem antecedentes e consequências semelhantes a outras dependências, como alcoolismo, apostas e desordens alimentares. Em todos os casos, existe impulso para agir de determinada forma, ignorância sobre os riscos envolvidos e repetidas tentativas de interromper o consumo. Mais tarde, Hirchsman (1992) tratou o fenômeno da dependência em substâncias químicas e em comportamentos (apostas em jogos de azar) como formas de consumo compulsivo e propôs bases para uma teoria geral do consumo compulsivo, a partir da percepção que indivíduos têm sobre a autodeclarada compulsão.

Pouco depois do estudo de Hirschman (1992), a forma de consumir pornografia começou a mudar drasticamente (GARLICK, 2011; LOVE et al., 2015; PIZZOL et al., 2016). Antes da popularização da Internet, o consumidor enfrentava barreiras sociais (que podiam estigmatiza-lo), psicológicas (causando constrangimento), financeiras (custo geralmente alto para alugar ou comprar filmes 
ou revistas) ou de acessibilidade (eram vendidos apenas em locais públicos, como bancas de jornal ou em locadoras de filmes), para obter estímulos sexuais visuais. O acesso passou a ser instantâneo, gratuito, irrestrito, privado e ilimitado (GRIFFITHS, 2012; YOUNG, 2008), expandindo-se em escala sem precedentes (LOFGREN-MARTENSON; MANSSON, 2010; MCNAIR, 2002; LOVE et al., 2015; PETER; VALKENBURG, 2006). Qualquer adolescente tem à sua disposição em uma semana mais material pornográfico do que gerações anteriores poderiam consumir durante toda a vida (COOPERSMITH, 2006).

Alguns estudos mostram que indivíduos que utilizam Internet excessivamente apresentam, em alguns casos, interesse de usá-la para fins sexuais (YOUNG, 1998; SCHWARTZ; SOUTHERN, 2000). O tempo que esses usuários investem na Internet está diretamente relacionado a consequências negativas por eles relatadas (COOPER et al., 1999). Analogamente, usuários de pornografia online apresentam média de consumo de 10 a 25 horas por semana (COOPER et al., 1999). Somente considerando o tempo investido, é possível conjecturar que uma série de atividades do cotidiano e relações interpessoais pode ser afetada (SCHNEIDER, 2000).

Se por um lado estudos recentes das áreas de Psicologia (GRUBBS et al., 2018; BRAND et al., 2011), Psiquiatria (PARK et al., 2016), Economia (EDELMAN, 2009), Religião (PERRY, 2017) e Sociologia (MCCORMACK; WIGNALL, 2017) retratam o consumo de pornografia on-line como uma forma de dependência, semelhante a resultados de outros estudos sobre dependência química (LOVE et al., 2015; OLSEN, 2011; VAN DEN EIJNDEN, et al., 2010; KÜHN et al., 2014) e dependência comportamental (LEMMENS et al., 2015; KELLET; 
TOTTERDELl, 2009), por outro lado há diferenças observáveis entre formas de consumir consideradas pela literatura com o que tem surgido no caso do consumo compulsivo de pornografia on-line (PHILLIPS et al., 2012; LEMMENS et al., 2015).

Essa nova forma de consumo compulsivo, diferentemente das que Hirschman (1992) considerou, não resulta em danos físicos por overdose, não deixa sinais no corpo que possam ser percebidos por terceiros, não gera comprometimento financeiro (a oferta de conteúdo gratuito é inesgotável), há baixa ou nenhuma percepção de riscos à saúde e a imagem social não é comprometida, já que o consumo pode ser escondido de familiares, cônjuges e amigos (COOPER et al., 2000). As consequências encontradas em alguns estudos concentram-se em problemas na família (DORAN; PRICE, 2014; YAMOAH; DEI, 2015), em falta de atenção no trabalho (WRIGHT; RANDALL, 2012) e nos estudos e relacionamentos sexuais (PARK et al., 2016).

Buscando contribuir para os esforços de diferentes áreas do conhecimento, particularmente a área de Comportamento do Conumidor, para criar um amplo entendimento do consumo compulsivo de pornografia on-line, a partir de como o cérebro é modificado (HILTON, 2013), ou de como o indivíduo comporta-se em seus grupos sociais (MCCORMACK; WIGNALL, 2017), esta tese tem por finalidade descobrir padrões de comportamento a partir do que consumidores compulsivos de pornografia on-line dizem sobre si, de sua relação com o consumo e de como interpretam as influências desse consumo em diversos aspectos de suas vidas. 


\subsection{Objetivo}

Este trabalho buscou investigar padrões de comportamento compulsivo dentro de uma realidade recente, ainda não explorada na literatura de comportamento do consumidor - o consumo compulsivo de pornografia on-line procurando identificar, na perspectiva dos consumidores, antecedentes e consequências dessa nova forma de consumo compulsivo.

\subsection{Relevância}

A literatura na área de Marketing apresenta lacunas decorrentes da não exploração de aspectos que parecem próprios de quem consome pornografia e que afetam drasticamente a vida dos consumidores, incluindo a possibilidade de desenvolver compulsão sexual.

A associação do consumo compulsivo de pornografia com outras compulsões de origem virtual não foram encontradas na literatura de Marketing. Pouco se sabe também sobre o consumo compulsivo de internet e do uso de redes sociais, embora já seja objeto de interesse para outras áreas do conhecimento, dentro do contexto de dependência (KUSS; LOPEZ-FERNANDEZ, 2016). Essas e outras formas de consumo desordenado podem atuar junto ao consumo de pornografia online, potencializando-o ou alterando efeitos observados.

Acrescentam-se às discussões acadêmicas particularidades do consumo compulsivo, como um serviço sem custo, que não se esgota, não sacia e não tem risco de overdose danosa à integridade física (LOVE et al., 2015). Consumo em que não há acúmulo de bens indesejados (DE OLIVEIRA et al., 2004), mas no qual, por 
outro lado, existe troca por sensações positivas, por prazer e pela regulação de emoções negativas (COOPER et al., 2000).

Neste estudo apliquei no campo de comportamento do consumidor conceitos explorados em outras áreas da ciência (i.e. Psicologia, Biologia e Sociologia), que ainda não consideraram a pornografia on-line como forma de consumo compulsivo. A partir de relatos e entrevistas com consumidores que se autodeclaram compulsivos, busquei conectar estudos encontrados na literatura sobre diversas formas de consumo compulsivo a discussões em outros campos do conhecimento, sobre efeitos e causas da compulsão em consumir pornografia online.

O trabalho também contribui para a compreensão deste tipo de consumo no panorama recentes, do COVID-19. Artigo recém publicado (MESTRE-BACH et al., 2020) discute o uso da pornografia durante a pandemia e o impacto que poderá ter na vida das pessoas, tendo em vista o cenário de distanciamento social.

Os estudos de consumo compulsivo têm-se baseado em grupos de foco ou em grupos de dependentes, como os Narcóticos Anônimos (MENDELSON; MELLO, 1986), Alcoólatras Anônimos (HIRSCHMAN, 1992) e Devedores Anônimos (PÊSSOA et al., 2016). Este estudo é único, na área do comportamento do consumidor, a imergir, por meio do método netnográfico, em uma comunidade on-line onde se reúnem em anonimato consumidores compulsivos de pornografia, com o objetivo comum de expor suas visões sobre sua relação com o consumo compulsivo. Meu histórico, que já fui em passado recente consumidor compulsivo de pornografia on-line, ajudou na integração na comunidade e na interpretação de antecedentes e consequências que emergiram durante a investigação. 


\subsection{Delimitação do estudo}

O estudo do de consumo compulsivo, em Marketing, apoia-se em modelos teóricos emprestados da patologia, sociologia, neurobiologia e psicologia. Nesta tese, estive apoiado em traços da personalidade que criam pré-disposições ao consumo de pornografia on-line, bem como na teoria de aprendizagem (DAVISON; NEALE, 1986; HOCH; LOWESTEIN, 1991) que também foi adotada por Hirschman (1992).

Não são do interesse deste estudo o mercado consumidor de pornografia online, as estratégias de propaganda com uso de soft porn, as discussões morais a respeito da liberdade de a consumir, nem efeitos do acesso precoce desse conteúdo sobre crianças ou adolescentes. As teorias provenientes da psicologia e da psiquiatria, que tratam de vícios, também não foram utilizadas como alicerce para este estudo. 


\section{2 \\ Revisão de Literatura}

Para suportar o objetivo deste estudo, foram apresentados as definições dos termos utilizados na literatura, os estudos de consumo compulsivo, suas características e subdivisões, o estudo de Hirschman (1992) que vai na direção de uma teoria geral do consumo compulsivo e a lacuna aberta pelo consumo compulsivo de pornografia on-line nos estudos de comportamento do consumidor, considerando como norte a teoria de aprendizagem. Por fim, faz-se considerações a respeito do perfil geral do consumidor compulsivo a fim de nortear o método, isto é, a escolha do sexo, faixa etária e estado civil dos relatantes da comunidade.

\subsection{Conceituação utilizada na literatura}

Faz-se necessário delinear os termos e conceitos utilizados pela literatura de consumo compulsivo, pois nem sempre a diferença entre eles é clara. Por exemplo, um indivíduo que está experimentando um impulso de consumo, pode satisfazer esse desejo de várias formas: a cleptomania, a compra excessiva ou comportamento compulsivo (SCHUSTER et al., 2016). Atento à importância de serem definidos os termos, Hassay e Smith (1996) explicam: o caçador (consumidor) pode ser motivado de várias formas: pela caça (ir às compras), pela matança (comprar) ou pelo disparo de uma arma para se entreter (gastar).

A dependência ou adição (addiction) é uma doença crônica provocada por mudanças no cérebro estimuladas através do uso constante de substâncias ou de vícios comportamentais (VOLKOW et al., 2011). Na área de comportamento do consumidor, as dependências químicas ou comportamentais (i.e. apostas, videogame) são consideradas "análogas ao comportamento compulsivo" 
(HIRSCHMAN, 1992, p. 158). Rook e Hoch (1985) e outros pesquisadores entendem da mesma forma (ver HOCK; LOWESTEIN, 1991; VALENCE et al., 1988), comparando o consumo excessivo de drogas e a bulimia ao consumo compulsivo.

Até o momento, não há consenso quanto à classificação, se se chama dependência, compulsão ou vício. Há autores que defendem que essas características são próprias de comportamento compulsivo (D'ASTOUS, 1990; FABER et al., 1987), outros sugerem que se trata de vícios (ELLIOTT, 1994; SCHERHORN, 1990). Scherhorn (1990), por exemplo, argumenta que é mais apropriado chamar de vício do que compulsão, porque há prazer atrelado aos atos realizados, enquanto a compulsão envolve somente sentimento negativo. No entanto, Faber e colegas (1987) discordam, defendendo que, na compulsão, também há sentimentos positivos envolvidos. Nesta tese, adotarei a interpretação de que essas dependências são formas de comportamento compulsivo (FABER et al., 1987; HIRSCHMAN, 1992).

A maioria dos estudos sobre consumo compulsivo tem como norte o Transtorno Obsessivo-Compulsivo (TOC), suportado na DSM-V (Manual Estatístico de Doenças, quinta edição) da American Psychiatric Association (APA). Até o penúltimo manual de diagnóstico e estatístico de transtornos mentais (DSMIV), os transtornos de consumo excessivo e consumo compulsivo eram tratados separadamente. No atual sistema de avaliação são considerados de mesma categoria, variando de leve a grave. Em outras palavras, cada substância é observada separadamente, mas todos são diagnosticados com base nos mesmos critérios gerais. Antes, um psiquiatra poderia diagnosticar transtorno de abuso de 
substância (consumo compulsivo) com apenas um sintoma, agora o transtorno de uso moderado de substância no DSM-V requer dois a três sintomas de uma lista de onze, sendo consideradas no novo manual as dependências químicas e comportamentais como Substance-Related and Addictive Disorders (HASIN et al., 2013).

Essa mudança de diagnóstico é compreensível porque a maioria dos pacientes com TOC apresentam tanto obsessões como compulsões (APA, 2000). Contudo, nem todo comportamento compulsivo é obsessivo (WORKMAN; PAPER, 2010). Por obsessão entende-se pensamentos e temores que são recorrentes no indivíduo. A compulsão tem caráter repetitivo relacionado ou não a substância ou comportamento que se tem obsessão (CHOU-GREEN et al., 2003). Segundo Chou-Green e colegas (2003), o indivíduo apresenta obsessão, por exemplo, quando está excessivamente preocupado com algo que, aparentemente, não lhe oferece risco (i.e. germes e bactérias em um local) e a resposta a essa situação também foge da normalidade, como atos repetidos de limpeza (compulsão).

São distintos também o conceito de consumo compulsivo e impulsivo (HIRSCHMAN; STERN, 1999). A definição de consumo compulsivo, adotada por O’Guinn e Faber e reiteradas vezes pela literatura é: “a compra repetitiva, crônica, que se torna a primeira resposta a eventos ou sentimentos negativos" (O'GUINN; FABER, 1989, p. 155), pois sugerem alívio a estados emocionais negativos como ansiedade e tristeza (HIRSCHMAN; STERN, 1999). Diferentemente da compulsão, a impulsão pode ocorrer a qualquer momento e pode ser influenciada por ações de marketing, enquanto a compulsão é processo interno, ativado por gatilhos externos ou internos (DITTMAR et al., 1996). 
Há que diferenciar também consumo compulsivo de compra compulsiva (DE OLIVEIRA et al., 2004) ou impulsiva (PÊSSOA et al., 2012). Ainda que os conceitos tenham semelhança, o consumo compulsivo é o consumo de um produto ou serviço de forma descontrolada; a compra compulsiva é a aquisição de qualquer produto ou serviço em grande quantidade, independentemente se o indivíduo irá utilizar ou não, e, em alguns casos, sem ter como pagar pela aquisição (ACHTZIGER et al., 2015; SHETH et al., 2001). Segundo Kukar-Kinney e colegas (2016), compradores compulsivos são vulneráveis, pois demonstram falta de controle em situação de compra. Já a compra impulsiva é uma compra súbita, sem qualquer planejamento, consequência de forte resposta afetiva positiva após o ato da compra (MOWEN; MINOR, 2003).

\subsection{Os estudos de consumo compulsivo}

Diferente do consumo regular de um determinado produto, o consumidor compulsivo apresenta desejo incontrolável de obter, usar ou experimentar uma substância ou uma atividade (O'GUINN; FABER, 1989). No primeiro caso, há prazer e liberdade para escolher; no segundo, há necessidade, mas já não existe liberdade e às vezes cessa o prazer (KOOB; LE MOAL, 2008; PHILLIPS et al., 2012). Como a água e o alimento são necessários à vida, a compulsão cria a ilusão de que é essencial à sobrevivência (ROOK; HOCH, 1985). Essa diferença não é causada somente pela frequência ou pela quantidade consumida, mas envolve também motivações, consequências e o tipo de estímulo (O'GUINN; FABER, 1989). Para Faber e O'Guinn (1989), cerca de $1,1 \%$ a 5,9\% dos norte-americanos desenvolvem algum tipo de consumo compulsivo. Black (1997), para a mesma população, mas com outra amostra, estimou a parcela entre $2 \%$ e $8 \%$. Anos mais 
tarde, Ditmar (2005) estimou que a quantidade de consumidores no país havia passado de 10 milhões.

Para Young (2008), seis características distinguem um consumidor compulsivo: (1) saliência, quando a dependência molda completamente a personalidade do indivíduo, desde suas emoções e pensamentos até seu comportamento; (2) euforia, que é a excitação e a busca de recompensa acima da razão; (3) tolerância, que é o aumento da intensidade do comportamento para atingir o nível de satisfação desejado; (4) tristeza, por não conseguir recusar o comportamento de que é dependente; (5) conflito, que é a tensão em não querer consumir mas necessitar do comportamento; e (6) remorso por ter falhado em resistir à tentação (relapso) (YOUNG, 2008). Em alguns casos, o estágio de compulsão poderá levar o indivíduo a ter pensamentos suicidas, motivados pela tristeza de falhar repetidas vezes durante o processo de recuperação da dependência (YUODELIS-FLORES; RIES, 2019).

Quando se usa o termo "consumo compulsivo", está-se falando de um comportamento do consumidor inadequado, geralmente excessivo e claramente perturbador para quem apresenta o quadro (FABER et al., 1987). Pode ser manifestado, dentre outras formas, como: compulsão alimentar (LEE et al., 2000; FABER et al., 1995), compra compulsiva on-line (CHANG et al., 2011; JOHNSON; ATTMANN, 2009), apostas (SCHLOSSER et al., 1994), cleptomania (MCELROY et al., 1991), bulimia (TRAUTMANN-ATTMAN; JOHNSON, 2009), uso indevido do cartão de crédito (PALAN et al., 2011), açambarcamento (acúmulo de objetos obsoletos e a consequente dificuldade em se desfazer deles) (CHERRIER; PONNOR, 2010). 
Segundo Nataraajan e Goff (1992), as várias manifestações do consumo compulsivo podem ser distinguidas, por sua vez, com base nos antecedentes e nas consequências do consumo. Na literatura encontram-se como alguns antecedentes baixa autoestima, ansiedade e depressão (D'ASTOUS; 1990; FABER; O'GUINN, 1988; SNEATH, et al., 2009; SCHERHORN et al., 1990), propaganda (HING et al., 2015), família desestruturada durante a infância (HIRSCHMAN, 1992; RINDFLEISCH, 1996), influência dos pares e amigos (GUO; CAI, 2011) e impulsos provocados por fantasias (FABER; O’GUINN, 1992).

Faber e colegas (1987) entendem que indivíduos se envolvem em comportamentos compulsivos como forma de regular estresse ou para superar emoções negativas. Na mesma linha, Darrat e colegas (2016) concordam que o consumo compulsivo é uma dependência comportamental ou química, que pode ser provocada e sustentada por emoções ou eventos negativos. Ironicamente, enquanto os consumidores buscam estímulos externos para melhorar estado emocional negativo, o efeito é uma satisfação momentânea, acompanhada de redução da satisfação geral com a vida, o que leva a mais ansiedade e podem torna-los deprimidos (RUVIO et al., 2014). Em resumo, há um ciclo "negativo-positivonegativo", proposto por Saraneva e Saaksjarvi (2008), que ocorre com os consumidores compulsivos e costuma repetir indefinidamente até levar a mais complicações, como a depressão e a vontade de dar fim a vida.

Rindfleisch e colegas (1996) encontraram em famílias que apresentam problemas estruturais, como pais divorciados ou separados, maior propensão a terem filhos com níveis mais elevados de consumo compulsivo, quando comparadas a famílias bem-estruturadas. Roberts e colegas (2004) confirmaram os 
achados, aplicando outra escala de consumo compulsivo (VALENCE et al., 1988) em cultura diferente (México). Isso ocorre porque relacionamentos disfuncionais afetam a estabilidade do indivíduo (RINDFLEISCH et al., 1996). Na mesma esteira estão outras influências sociais, como amizades, normas sociais e a propaganda, capazes de instigar e facilitar o uso de produtos e comportamentos potencialmente viciantes, especialmente durante a adolescência, quando muitos hábitos são estabelecidos (BAUMAN; ENNETT, 1996)

Hing e colegas (2015) aplicaram questionário a 544 apostadores que apresentavam diversos níveis de compulsão por apostas a fim de entender o efeito da propaganda sobre eles e descobriram que o marketing age como um tipo de gatilho que leva o consumidor a agir na direção planejada. Usado de outra forma, propagandas podem servir de desestímulo ou prevenção ao consumo compulsivo (MARTIN, 2013). É possível estimular os consumidores compulsivos de cigarros com mais propaganda sobre o produto, amostras grátis, programas de fidelidade e patrocínio em eventos. No entanto, se o objetivo for a prevenção, campanhas de conscientização dos danos, meios de bloquear o acesso, reforço na autoestima são propostos (MARTIN, 2013).

Quando se investigam artigos de compra compulsiva, alguns antecedentes vistos em outras compulsões são encontrados, desde o artigo seminal de O'Guinn e Faber (1989), que encaixou conceitualmente a compra compulsiva a outras dependências, como o alcoolismo, desordem alimentar, consumo de drogas ilícitas e apostas, até o estudos mais recentes, como o de Lam e colegas (2018), que propôs conceitos para ajudar pesquisadores a melhorar esforços no estudo do materialismo e da compra compulsiva, há semelhança entre as compulsões. 
Faber e O’Guinn (1992), por exemplo, encontraram relação consistente entre compra compulsiva e outros fatores, como baixa autoestima, materialismo, impulsividade, solidão e transtorno obsessivo-compulsivo. Faber e colegas (1995) elaboraram dois estudos sobre compra compulsiva e alimentar. Comparando dois grupos com peso semelhante, encontraram que mulheres diagnosticadas com compulsão alimentar tinham maior propensão ao consumo compulsivo quando comparada às não-compulsivas e, analogamente, consumidoras compulsivas tinham maior probabilidade de desenvolver compulsão alimentar quando comparadas ao grupo de controle.

Diferente do consumidor compulsivo, as características dos compradores compulsivos são mais restritas. Considera-se um comprador compulsivo, segundo McElroy e colegas (1994), o indivíduo que apresenta três aspectos: 1) pensamentos irresistíveis, intrusivos e sem fundamento para comprar algo; 2) aquisição de bens desnecessários; ou 3) período de compras superior ao planejado inicialmente. De fato, os compradores compulsivos demonstram distúrbios de ansiedade com pensamentos obsessivos e comportamentos compulsivos que causam sofrimento e perturbação no dia-a-dia (LAM et al., 2018). Essas características interferem significativamente na concentração, na rotina, no trabalho, nos estudos, nos relacionamentos e em algumas outras atividades sociais (WRIGHT; RANDALL, 2012).

De forma semelhante, Solomon (2011) separou em três partes semelhantes: (i) a escolha não é livre, mas induzida por uma dependência ao produto; (ii) a recompensa é rápida e some instantaneamente; (iii) o indivíduo sente-se culpado, com remorso ou arrependido após o efeito passar. Para Medeiros e colegas (2015) 
os estudos ainda não são conclusivos sobre as características que levam a compra compulsiva, pois há inúmeras causas, desde bioquímica (i.e. níveis de serotonina), psicológica (i.e. depressão, ansiedade, baixa autoestima) ou sociológica (i.e. experiências familiares). Além disso, compradores compulsivos geralmente compram itens dos quais não precisam ou não podem pagar (HOYER; MACINNIS, 2001), o que resulta em dívidas incontroláveis (O’GUINN; FABER, 1989).

Segundo Pêssoa e colegas (2016), que entrevistaram 18 pessoas em um grupo de apoio chamado Devedores Anônimos (DA) a fim de compreender as motivações, hábitos e experiências, as consumidoras compulsivas reconhecem com vergonha que não possuem controle de suas vidas e estão mais suscetíveis a estímulos de propaganda ou gatilhos como a palavra "liquidação". Kukar-Kinney e colegas (2012) sugerem que compradoras compulsivas respondem mais a estímulos externos que as não-compulsivas, tais como promoções em que há pressão por tempo (i.e. "últimas peças no estoque") ou social (i.e. "mais de mil pessoas já compraram").

As consequências podem variar também pela idade do consumidor (LIU; LAIRD, 2008), sendo adolescentes mais suscetíveis a tornarem-se consumidores compulsivos do que adultos (PECHMAN et al., 2005). No entanto, com algumas exceções (SHOAF et al., 1995), estudos anteriores com consumidores concentraram-se amplamente no comportamento de compra compulsiva de adultos e pouco foi observado em relação a adolescentes que apresentam consumo compulsivo de alguma substância ou comportamento (DESARBO; EDWARDS, 1996). Segundo Liu e Laird (2008), para os adultos, a redução de estresse simbolizada pela compra é o fator que mais atrai, enquanto que adolescentes 
buscam a compra compulsiva como meio de estabelecer identidade própria entre seus pares.

Independentemente da causa ou do conjunto delas, após a compra e a consequente tristeza por ter recaído, os compradores compulsivos sentem-se impelidos a ocultar, doar, devolver ou descartar compras realizadas (FABER; O’GUINN, 1988; HASSAY; SMITH, 1996). Para quem tem compulsão alimentar, a redução do estado emocional leva a comer mais (PARYLAK et al., 2011) e para quem tem compulsão por apostas, dissipar as reservas em jogos (SCHLOSSER et al., 1994).

\subsection{Em direção a uma teoria geral de consumo compulsivo}

O artigo de Hirschman (1992) veio na esteira dos estudos iniciais no campo de comportamento do consumidor da década de 1980 e buscou lançar bases de uma teoria geral de consumo compulsivo, ao integrar diversas teorias de adição, comportamental e química, provenientes de várias disciplinas (Comportamento do Consumidor, Sociologia, Psiquiatria e Psicologia).

Hirschman (1992) trata as dependências químicas e comportamentais como formas de consumo compulsivo. Os dois pilares de seu estudo foram a consciência da adição (dependência) a fim de contribuir a uma teoria geral de consumo compulsivo.

Segundo Hirschman (1992), as dependências químicas, são mais facilmente reconhecidas, uma vez que as substâncias alteram o comportamento do indivíduo imediatamente após a sua ingestão (HIRSCHMAN, 1992). Algumas drogas podem levar à morte por dose excessiva, outras não (HIRSCHMAN, 1992), mas quase 
todas geram comprometimento financeiro, deixam sinais visíveis no corpo e causam problemas sociais, na família e no trabalho (WRIGHT; RANDALL, 2012; PERRY, 2016; LOVE et al., 2015). Algumas podem ser livremente comercializadas, enquanto algumas são ilegais ou têm restrições etárias para consumo, como o álcool e o fumo (MORELLI et al., 2017). Nas dependências de origem comportamental, o indivíduo tem suas vidas social e material prejudicadas, entretanto não há danos físicos (BRAND et al., 2016). Drogas e comportamentos distinguem-se nas consequências, mas todas provocam dependência (PHILLIPS et al., 2012).

Duas foram as bases utilizadas por Hirschman para interpretar os relatos: a primeira foi a divisão das teorias que embasam o fenômeno da compulsão pela ótica dos traços da personalidade (MENDELSON; MELLO, 1986), da patologia (PEELE, 1985) e da sociologia (DAVISON; NEALE, 1986), entendo que essas teorias não são independentes entre si, mas todas elas contribuem para o entendimento do fenômeno da compulsão (HIRSCHMAN, 1992).

Os traços da personalidade tratam o indivíduo em sua complexidade considerando as predisposições e tendências que possui, classificando-os em dois grupos: "angustiados" e "sociopatas". Os angustiados são pessoas que se sentem incapazes de administrar os sentimentos e buscam substâncias ou comportamentos externos para escapar da ansiedade e devolver o controle das emoções (LEON, 1984; HIRSCHMAN, 1992). Tipicamente, este tipo de vício está associado a indivíduos que passaram a infância com família disfuncional (HIRSCHMAN, 1992) e que, tomados por sentimento de incompetência para atos sociais mais simples (BRISTER; BRISTER, 1987), entendem que a ingestão de determinadas 
substâncias, ou aderência a um comportamento viciante, podem ser vistos como ato racional (HIRSCHMAN, 1992). Os sociopatas apresentam distúrbios (parafilias) de ordem patológica, isto é, perversões sexuais consideradas incomuns a uma pessoa sadia. De origem grega, a parafilia (para - "fora de", e philia -“amor”) é um comportamento sexual cujo prazer não está no ato em si, mas é atribuída a uma atividade ou objeto de desejo, um interesse sexual intenso e persistente em qualquer coisa diferente da estimulação genital e de carícias com parceiros humanos que consentem com o ato. Sobre esta segunda forma de consumo compulsivo, trataremos mais a frente no tema de distúrbios sexuais.

A segunda base é a teoria de aprendizagem, inicialmente postulada por Davison e Neale (1986) que entende a formação da dependência como "respostas aprendidas que são adquiridas e mantidas porque reduzem o estresse” (p. 258). Para Hoch e Loewenstein (1991) essa alteração ocorre no autocontrole, desejo, força de vontade e autoestima do indivíduo.

A partir da própria experiência como dependente química, Hirschman assumiu a priori, dois temas que seriam recorrentes nos consumidores compulsivos e, após aplicação do método (a posteriori) encontrou outros cinco temas (Quadro $1)$. 
Quadro 1 - Proposições de Hirschman (1992) e teorias associadas

\begin{tabular}{|c|c|c|}
\hline Tema & Justificativa & Bibliografia \\
\hline $\begin{array}{l}\text { Dependências em } \\
\text { série }\end{array}$ & Indivíduos têm mais de uma dependência; & $\begin{array}{l}\text { O'GUINN; FABER, } \\
1989\end{array}$ \\
\hline $\begin{array}{l}\text { Mudanças de vida } \\
\text { relevante }\end{array}$ & $\begin{array}{l}\text { Acontecimentos que mudam a vida e trazem } \\
\text { insegurança, desconforto, irritação; }\end{array}$ & SCHOUTEN, 1991 \\
\hline $\begin{array}{l}\text { Decepcionar os } \\
\text { parentes }\end{array}$ & $\begin{array}{l}\text { Os consumidores desejam esconder o consumo } \\
\text { de pessoas próximas por medo de decepcioná- } \\
\text { las; }\end{array}$ & ROOK, 1987 \\
\hline $\begin{array}{l}\text { Famílias } \\
\text { desestruturadas }\end{array}$ & $\begin{array}{l}\text { Indivíduos começam a consumir por influência } \\
\text { dos pais ou do ambiente familiar degradado; }\end{array}$ & $\begin{array}{l}\mathrm{HOCH} \text {; } \\
\text { LOWESTEIN, } \\
1991\end{array}$ \\
\hline $\begin{array}{l}\text { Limites do } \\
\text { consumo }\end{array}$ & $\begin{array}{l}\text { Indivíduos impõem limites ao consumo, para } \\
\text { afastar efeitos negativos da sua família; }\end{array}$ & $\begin{array}{l}\text { O'GUINN; FABER, } \\
1989\end{array}$ \\
\hline $\begin{array}{l}\text { Pensamento } \\
\text { suicida }\end{array}$ & $\begin{array}{l}\text { Indivíduos tentam controlar o consumo e impor } \\
\text { limites, mas, sem êxito, começam a perder a } \\
\text { esperança; }\end{array}$ & RUSSELL, 1979 \\
\hline Recaídas & O indivíduo não consegue parar de consumir. & PEELE, 1985 \\
\hline
\end{tabular}

A primeira contribuição do estudo foi observar que dependências químicas têm diversas consequências em comum com algumas formas de consumo compulsivo, mostrando ligações entre teorias sociais, patológicas e genéticas a respeito do fenômeno da dependência (HIRSCHMAN, 1992). A segunda contribuição foi propor a teoria de aprendizagem como espinha dorsal presente em todas as dependências, elencando sete consequências no consumo excessivo de substâncias químicas e comportamentos compulsivos.

Por fim, Hirschman (1992) mostrou como a consciência da dependência está ligada a outras formas de consumo compulsivo e como consumidores compulsivos e não-compulsivos avaliam a sua relação com a substância. 


\subsection{Consumo compulsivo de pornografia on-line}

Como ainda não há estudos na área de consumo compulsivo que abordem o consumo de pornografia on-line, o arcabouço teórico para suportar o método serão provenientes de outras áreas - assim como fez Hirschman (1992).

Para Ross e colegas (2012), o consumo compulsivo de pornografia on-line apresenta para o usuário cinco consequências principais: problemas no dia a dia; sensação de perda do autocontrole; mal estar por usar a Internet para fins sexuais; percepção subjetiva de que está dependente do consumo; e clara noção de que a dependência requer intervenção ou tratamento. Contudo, a intensidade das consequências pode variar, de acordo com o tipo de material explícito visualizado, a frequência da exposição e características pessoais e contextuais dos usuários (ROSS et al., 2012; LAYDEN, 2010).

Alguns autores preferem classificar um consumidor de pornografia on-line como dependente a partir do número de horas de consumo por semana (COOPER et al., 1999), da percepção do indivíduo sobre sua experiência (YOUNG, 2008) ou do nível de esforço para buscar pornografia on-line e de como o uso foge de seu autocontrole (GRUBBS et al., 2015). Embora a dependência de pornografia on-line ainda não seja reconhecida como patologia no DSM-V (GRUBBS et al., 2015), estudos advogam que deveria ser incluída como um tipo de dependência em Internet (LOVE et al., 2015).

A dependência em pornografia guarda semelhanças a outras dependências, quando comparada a estudos que utilizaram imagens do cérebro (LOVE et al., 2015). Childress e colegas (2008), a partir de imagem do cérebro de indivíduos com dependência de cocaína que foram expostos a estímulos pornográficos, concluíram 
que o cérebro responde da mesma forma, quando estimulado por uma droga ou por imagens sexuais. Kuhn e Gallinat (2014) mediram a quantidade de massa cinzenta no cérebro de indivíduos que consomem pornografia on-line em excesso e a compararam com a de grupo de controle. Os resultados mostraram relação significativa, e negativamente proporcional, entre a quantidade de massa cinzenta e a quantidade de horas de consumo de pornografia on-line (KUHN; GALLINAT, 2014).

O consumo excessivo de pornografia on-line gera insatisfação com a vida (PETER; VALKENBURG, 2006), solidão (YODER; VIRDEN; AMIN, 2005), problemas no trabalho (HERTLEIN; PIERCY, 2012; WRIGHT; RANDALL, 2012), disfunção erétil e alteração da libido (HEIDELBAUGH, 2015), menor satisfação sexual no casamento (PERRY, 2016), baixa autoestima (LEVERT, 2007), propensão à depressão (WEAVER et al., 2011), divórcio (BAUSERMAN, 2006; REID et al., 2011), associação a outras dependências (BRAND et al., 2011), percepções negativas quanto ao parceiro (FISHER; BARAK, 1999) e em outras situações da vida (LOVE et al., 2015). Outros estudos o vêem como positivo (PRAUSE; PFAUS, 2015; HALD; MALAMUTH, 2008; COLEMAN, 2002; ELDERS, 2010; GROV et al., 2011) ou simplesmente inofensivo (KOHUT et al., 2017).

Schneider (2000) utilizou amostra de 91 mulheres que tinham sido casadas em média por 12 anos e que buscaram terapia de casal com parceiros que consumiam pornografia on-line, concluindo que elas frequentemente associavam a pornografia on-line a um adultério, sendo o consumo compulsivo de pornografia pelo marido a principal causa do divórcio. Em outro estudo, Bechara e colegas 
(2003) mostram que mulheres cujos parceiros consomem pornografia relataram ter níveis mais elevados de estresse, considerando o consumo como ameaça ao relacionamento pela redução do envolvimento emocional. Bauserman (2006) reportou que de 1600 divórcios, 992 tiveram como causa importante o consumo de pornografia pelos os cônjuges.

Existem dois tipos possíveis de impactos relacionados o consumo de pornografia on-line (HERTLEIN; PIERCY, 2012; PIZZOL et al., 2015): comportamentos não-parafílicos que não são considerados “excessivos” por não causarem danos a outrem, como vício ou promiscuidade; e comportamentos parafílicos, como desejo por prostitutas, travestis, zoofilia, sadismo, masoquismo, voyeurismo e pedofilia. Loftus (2008) avaliou alguns websites e mostrou que cerca de $42 \%$ dos vídeos pornográficos on-line envolviam cenas agressivas. Cooper e colegas (2002) fizeram avaliação semelhante e constataram que quase a metade dos vídeos tinha cenas de sexo violentas.

Nota-se, portanto, que, mesmo a pornografia on-line não sendo considerada como comportamento compulsivo na área de marketing, ela apresenta características comuns à maioria das compulsões, que podem ser separadas em dois grupos: antecedentes e consequências.

\subsection{0 perfil do consumidor compulsivo de pornografia on-line}

Por fim, quanto ao perfil demográfico dos consumidores compulsivos de pornografia on-line, é preciso considerar alguns achados da literatura sobre a faixa etária, o sexo e o estado civil. 
Consumidores de pornografia on-line são em geral adultos ou jovens, do sexo masculino, solteiros, sexualmente ativos e permissivos, com baixo índice de envolvimento com alguma religião, e com acesso à Internet por algum dispositivo eletrônico (GRUBBS et al., 2015; PRICE et al., 2016; WILLOUGHBY et al., 2016). Para alguns, a pornografia on-line é usada como complemento à sexualidade off-line, enquanto para outros servem como substitutos, resultando em dependência sexual na Internet, que pode ser entendida como a interseção entre dependência na Internet e dependência sexual (GRIFFITHS, 2012).

Homens e mulheres reagem de forma distinta aos mesmos estímulos visuais pornográficos (WILLOUGHBY et al, 2016; RUPP et al., 2008; LYKINS et al., 2008). Nos homens, a pornografia parece estar associada à disfunção erétil (HEIDELBAUGH, 2015) e o consumo excessivo impacta significativamente a autoestima (TAYLOR; JACKSON, 2018). Homens também parecem ser mais influenciados pelo ato sexual e pela exposição de imagens, enquanto a mulher pelo contexto apresentado (RUPP et al., 2008). Por isso, homens tendem a se engajar com mais frequência e com menor idade em masturbação, no sexo casual e no consumo de pornografia, se comparados com mulheres (BAUMEISTER et al., 2001; PETERSEN; HYDE, 2010). Diversos estudos comprovam que assistir pornografia é atividade essencialmente masculina (BRIDGES; MOROKOFF, 2011; POULSEN et al., 2013; STACK et al., 2004), pois para a maioria das mulheres, o consumo de pornografia on-line é monótono, não emocionante ou até repulsivo (HALD, 2008; TRAEEN et al., 2004).

Diferentemente do consumo compulsivo de pornografia on-line, a compra compulsiva, tem incidência maior entre as mulheres, iniciando com idades entre 18 
e 30 anos (O'GUINN \& FABER, 1989; SCHERHORN et al., 1990; MCELROY et al., 1994). Trautmann-Attmann e Johnson (2009) argumentam que o sexo feminino considera como mais importante a aparência, sobretudo as consumidoras mais jovens, se comparado aos homens. Faber (1992) compreende que os produtos relacionados a estética aumentam os níveis de reconhecimento e aprovação dos pares.

Quanto ao faixa etária, o tempo de consumo e o tipo de material consumido (VANDONINCK et al., 2010; CARROLL et al., 2008; SHAPIRO, 2005) também é possível variar os efeitos da compulsão. Além de haver diferença na formação dos sistemas cerebrais de adolescentes e adultos (ASATO et al., 2010), as crianças que tem a partir de sete anos podem ser expostas acidentalmente à pornografia on-line por meio de seus smartphones ou quando chegar a puberdade e a curiosidade os fazerem buscar por conta própria (YBARRA; MITCHELL, 2003). Os jovens que hoje têm entre 20 e 29 anos tiveram contato primeiramente com revistas e filmes pornográficos em formato VHS ou em DVD, comprados. Posteriormente, o material passou a ser oferecido gratuitamente por meio da Internet, inicialmente em velocidade baixa, e, depois, em banda-larga (BRAUN-COURVILLE; ROJAS, 2009). Os que têm mais de 35 anos hoje, passaram a infância e a pré-adolescência sem contato com formato digital, tendo consumido pornografia, em sua adolescência, muito menos que um consumidor considerado como recreativo hoje (COOPERSMITH, 2006).

O estado civil também difere consideravelmente, uma vez que o consumo de pornografia on-line pode ser visto como um tipo de infidelidade marital (PERRY, 2016; HERTLEIN; PIERCY, 2012). Assim, os adolescentes possuem 
menos barreiras ao consumo que os adultos casados (antecedente) e, consequentemente, lidam com menos problemas a nível pessoal (consequência).

A parte dos aspectos demográficos, a tecnologia favoreceu a expansão do consumo (LOVE et al., 2015). O telefone celular é, muitas vezes, acessado pelo indivíduo assim que acorda e imediatamente antes de dormir (LEE et al., 2013). Um indivíduo em média consulta o smartphone 34 vezes por dia sem objetivo específico, simplesmente porque tornou-se um hábito (OULASVIRTA et al., 2012). Zewin (1997) identificou correlação positiva entre o número de parceiros sexuais no último ano (produto da revolução sexual) e o consumo de pornografia no mesmo período (resultado da tecnologia). Este mesmo estudo foi replicado na Noruega, com resultado semelhante (TRAEEN et al., 2006).

Kraus e Rosenberg (2014) estudaram 221 homens sobre o consumo de pornografia on-line. Pouco mais da metade (62\%) a consumia pelo menos três vezes por semana e $98 \%$ pelo menos uma vez por semana. Cooper e colegas (2004) separam em três grupos: usuários recreativos, os que buscam a pornografia para entretenimento e não se vêem dependentes; usuários em risco, mais assíduos, mas que não se consideram dependentes; e usuários compulsivos, que perdem a liberdade por não conseguir evitar o consumo. Vaillancourt-Morel e colegas (2017) fizeram estudo com 830 adultos que consomem pornografia on-line, que apresentaram o mesmo padrão de consumo: os recreativos $(75,5 \%)$, que assistiam em média 24 minutos de pornografia on-line por semana, consideraram ter níveis altos de satisfação sexual e níveis baixos de compulsão sexual, apresentando poucos problemas sexuais; os não-compulsivos, ou "altamente perturbados" (12,7\%), e os compulsivos $(11,8 \%)$ relataram níveis maiores de insatisfação sexual, mais tempo 
de consumo por semana e problemas sexuais. Para Vallerand (2008), os consumidores recreativos têm apenas apego apaixonado pelo consumo, enquanto os "compulsivos sexuais", que manifestam algum grau patológico, satisfazem sua vontade utilizando a Internet e se autodeclaram dependentes. Como a diferenciação dos dois primeiros grupos (recreativo e não-compulsivos) é tênue, não foram incluídos neste estudo, que se debruçou apenas àqueles autodeclarados como consumidores compulsivos. 


\section{3. Método}

O método compreendeu duas fases. Na primeira, utilizando pesquisa netnográfica, imergi nas histórias de vida relatadas em diários postados no site por membros da comunidade on-line "Como Parar" formada por indivíduos que se autodeclaram dependentes em pornografia on-line - semelhante a grupos de apoio como Alcoólatras Anônimos - e interagi de forma a absolver o modo com que eles enxergam a compulsão. Na segunda parte, entrevistei alguns dos consumidores compulsivos da comunidade a fim de aprofundar o entendimento de assuntos revelados na netnografia.

\subsection{Primeira fase - Netnografia}

Como se trata de método desenvolvido a partir da etnografia, a netnografia abarca seu protocolo e sua metodologia tem sido aplicada na área de consumo (KOZINETS，2015; SCARABOTO; FISCHER，2013; COSKUNER-BALLI; THOMPSON, 2013; JONES, 2005; MANN; STEWART, 2019) e em diferentes campos, como na Educação, em Relações Públicas, na Geografia, na Enfermagem e no Turismo (KOZINETS, 2015; TOLEDANO, 2017; RAGEH et al., 2013).

A netnografia é um método de imersão prolongada com os membros de uma comunidade on-line, seguido por tentativa de compreender e de comunicar determinada realidade por meio de interpretação densa, pormenorizada e profunda, de um universo social que é familiar a seus participantes, mas estranho a pessoas que não fazem parte da comunidade (KOZINETS, 2015). 
Por comunidade on-line entende-se agregações sociais emersas da Internet, quando um número suficiente de indivíduos empreende discussões públicas por um tempo, formando redes de relacionamentos pessoais no espaço virtual (RHEINGOLD, 1993). Essas redes seguem quase estritamente regras de relações presenciais e devem ser encaradas como verdadeiros espaços de cultura, sobretudo quanto ao conjunto de normas e à identidade que os definem (HOOKWAY, 2008; BOELLSTORFF, 2015). Entretanto, algumas características peculiares das comunidades on-line, como anonimato e acessibilidade, criam ambiente adequado para comunidades cujo fim é a reabilitação de comportamento e ajuda mútua dos membros participantes, que tendem a ser verdadeiros quanto a seus pensamentos porque $\mathrm{o}$ anonimato permite a abordagem de situações que gerariam constrangimento caso sua identidade fosse revelada (TAYLOR; JACKSON, 2018; WANG, 2018).

Comparada aos métodos qualitativos tradicionais, a netnografia é mais rápida, menos intrusiva, não necessita de transcrições e pode ser anônima quando há risco de constrangimento (MKONO, 2012). Sua estrutura permite que os consumidores consigam expressar atitudes e opiniões de forma mais profunda e sem preocupações, favorecendo o entendimento do fenômeno observado (MKONO, 2012).

Enquanto a coleta de dados da etnografia incorpora diferentes formatos (entrevistas, anotações, áudio, vídeo, fotos), a netnografia concentra-se na observação do participante por textos e por anotações do pesquisador (KOZINETS, 2014). Toda interação entre pesquisador e participantes, bem como de todos entre 
si, é fruto da experiência do pesquisador (BOELLSTORFF et al., 2012) e o eixo da interpretação (MKONO, 2012).

A netnografia, portanto, foi considerada para a primeira etapa deste estudo, não só pela dificuldade em encontrar fora do grupo indivíduos com dependência em pornografia on-line, que estivessem dispostos a expor fraquezas e conversar sobre elas, mas também porque os participantes do grupo assumem pseudônimos e comportam-se de forma anônima, dando-lhes maior liberdade para interação e diminuindo riscos à privacidade (KOZINETS, 2006). Em situações que envolvem riscos de constrangimento, como em comunidades de indivíduos que sofrem de doenças como câncer ou AIDS (DAVISON et al., 2000), a comunidade on-line passa a ser uma das poucas formas de se chegar aos indivíduos e compreender seu modo de ver (KOZINETS, 2006).

Historicamente, grupos de suporte são tidos como uma das principais formas de recuperação de indivíduos que sofrem de diferentes formas de adição (TRACY; WALLACE, 2016). São definidos como "processo de dar e receber assistência de indivíduos amadores que vivem condições e consequências semelhantes, a fim de recuperar-se a longo prazo do vício adquirido" (TRACY; WALLACE, 2016, p. 143).

A análise netnográfica é ainda mais relevante, porque indivíduos que recorrem a grupos de suporte on-line têm maior chance de se recuperar da dependência se comparado aos que não fazem uso da rede social (ATKINS; HAWDON, 2007). Recentemente, Taylor e Jackson (2018) estenderam as aplicações da netnografia ao caso de consumo de pornografia on-line, ao conduzirem estudo em uma comunidade norte-americana para entender como a 
dependência de pornografia on-line afetaria a "autopercepção da masculinidade" dos consumidores e seus reflexos na vida sexual.

Na comunidade Como Parar, os usuários criam diários para que outros membros possam acompanhar sua vida e os ajudem a superar dificuldades. Nesse espaço, o participante estabelece quais serão suas metas (7, 15, 30 dias sem consumir pornografia, por exemplo), utiliza o contador de tempo de abstinência online, promove a abstinência (total ou parcial) e busca conselhos baseados em casos práticos de sua vida.

O modelo proposto por Kozinets (2015) compõe-se de cinco etapas para aplicação da netnografia (Quadro 1). Neste estudo, a quinta etapa, a "validação das descobertas junto aos membros da comunidade", foi substituída por entrevistas com os voluntários, membros da comunidade, constituindo a segunda fase do método aqui empregado.

Quadro 2 - As cinco etapas da netnografia (KOZINETS, 2015, p. 135)

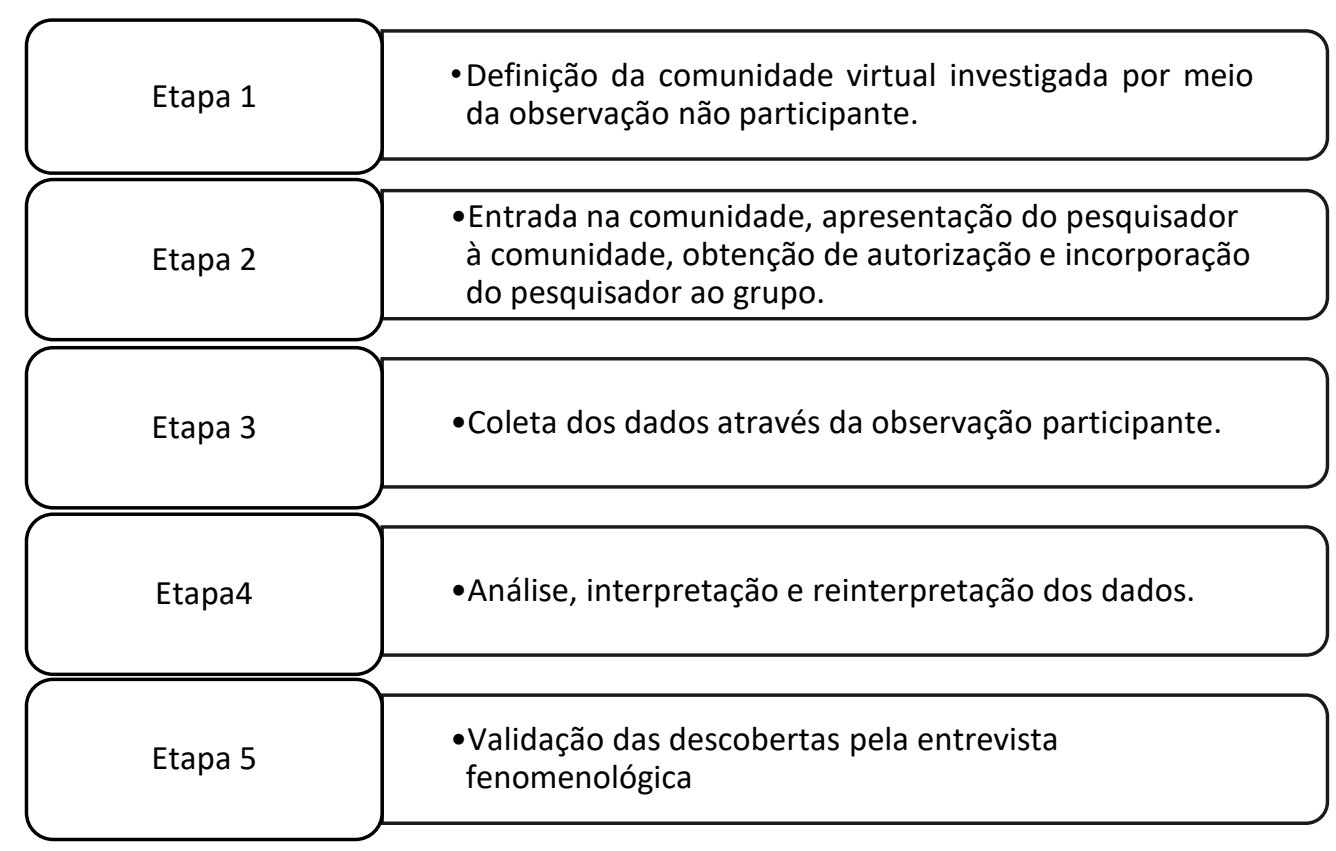




\subsubsection{Definição do campo}

Kozinets (2015) define seis critérios elementares para a escolha da comunidade: ser relevante, ser ativa, ser interativa, ser substanciais, ser heterogênea e ser rica em dados. Outros dois critérios foram adicionados, seguindo a netnografia aplicada por Cavaglion (2009): ter homogeneidade linguística-cultural (todos os participantes falam português e são brasileiros) e haver concentração no assunto, que é o objeto do estudo: a comunidade trata somente da dependência em pornografia on-line e não de pornografia em geral, nem de consumidores que a veem como positiva e gostam de consumi-la. Na comunidade investigada, todos reprovam o consumo, mesmo para fins recreativos.

Existem algumas comunidades on-line norte-americanas que têm por objetivo a troca de informações e a ajuda mútua para quem se autodeclara dependente em pornografia on-line. As principais comunidades são pornfree.com, nofap.org e yourbrainrebalanced.com. Nelas não há homogeneidade, porque acolhe indivíduos de diferentes culturas e países, que não utilizam a língua inglesa como oficial (exemplo: França, Itália, Alemanha etc.). No Brasil, a única comunidade relevante sobre pornografia on-line é a "Como Parar" (comoparar.com), um grupo de apoio on-line que reúne indivíduos brasileiros que buscam ajuda para vencer o consumo compulsivo de pornografia, por eles próprios intitulado "PMO" (pornografia, masturbação e orgasmo). Seus participantes atribuem consequências negativas do consumo de material pornográfico on-line em suas vidas.

Optou-se pela escolha do Como Parar, em vez de fóruns estrangeiros, porque, embora ambos esteja garantida a heterogeneidade das interações, somente 
na brasileira fica assegurada a compreensão linguística e a unidade cultural, uma vez que as redes estrangeiras congregam múltiplas nacionalidades. Na comunidade brasileira há somente nativos e se houvesse estrangeiros, poderiam ocorrer discrepâncias culturais que impactariam o resultado (RYE; UNDERHILL, 2019; MATTEBO et al., 2013; JONES, 2005).

Hald e Malamuth (2006) apontaram que o componente cultural é real e provavelmente impactou seu estudo sobre a percepção dos efeitos da pornografia, pois em um país "muito liberal, onde a pornografia é amplamente disponível e tradicionalmente não é vista como ruim, isto reduzirá sua percepção sobre possíveis males" (HALD; MALAMUTH, 2006, p. 622).

A comunidade "Como Parar" foi inaugurada no Brasil em 2014 e registrava, em fevereiro de 2020, mais de 8.481 membros cadastrados e 248.977 mensagens trocadas, sendo possível, a qualquer hora, encontrar por volta de 30 indivíduos interagindo nos diversos tópicos da comunidade, tendo em seu último recorde de visita 211 membros on-line simultaneamente. A procura pode ser explicada não só pela incidência de casos, e por ser a única comunidade brasileira com alcance significativo, mas pelo ambiente favorável a dependentes comportamentais, já que o fórum garante $\mathrm{o}$ anonimato na troca de informações entre indivíduos com interesse semelhante. Por ser uma comunidade aberta - sem necessidade de cadastro para ter acesso aos posts -, há maior facilidade de aproximação de indivíduos que desconhecem tal forma de ajuda.

Ademais, Como Parar atende aos seis pré-requisitos destacados por Kozinets (2014): é relevante, pois tem relação com a pergunta de pesquisa formulada; é ativa, pois a qualquer hora do dia há novos posts e comentários no 
fórum; é interativa, uma vez que em quase todo post há indivíduos comentando os temas propostos; é substancial, pois os que estão em recuperação encontram ajuda com profundidade para seus problemas; é heterogênea, uma vez que há seções para heterossexuais, homossexuais e mulheres, de diferentes idades; é rica em dados, porque o fórum existe desde 2014 e todo dia dezenas de indivíduos participam ativamente. Ademais, Como Parar atende aos pré-requisitos do estudo, pois encoraja os consumidores compulsivos em pornografia on-line a contar suas histórias, suas angústias e decepções por meio de diários, atualizados constantemente até a desistência ou o autocontrole da compulsão.

Dependendo do tipo de grupo de suporte (fórum), explica Kozinets (2015), o pesquisador pode trabalhar com uma de duas possibilidades de estudo. A primeira é o "estudo de comunidades on-line", para os casos onde o nicho (hobby) começa e termina na própria comunidade, como, por exemplo, o fã-clube de um jogo on-line, de uma novela ou de músicas. O segundo tipo, escolhido para este estudo, é a "pesquisa on-line em comunidade", que abarca uma área de interesse que transcende o ambiente virtual, uma vez que o fenômeno social do consumo de pornografia on-line atinge a vida pessoal e social do indivíduo.

A observação foi iniciada a partir de uma aproximação não-participante (lurking) de julho/2018 a abril/2019. Foi possível confirmar a escolha da comunidade como sendo adequada ao estudo, conhecer a linguagem e as normas do grupo, bem como o reconhecimento dos participantes mais experientes, que poderiam facilitar a entrada (CATTERAL; MACLARAN, 2001). Kozinets (2014) defende que deve ser feito contato com o proprietário do fórum para obter 
autorização para a pesquisa. Isto foi feito, tendo o proprietário autorizado e se colocado à disposição.

O primeiro passo na observação não-participante foi conhecer as regras que todo grupo ou fórum tem. Em Como Parar, as diretrizes são apresentadas em um tópico principal, as "Orientações básicas", utilizadas pelos moderadores para controlar violações dos termos pré-estabelecidos. O site define-se como "não necessariamente anti-masturbação, anti-sexo e anti-orgasmo" e afirma que "não advoga em favor do banimento da pornografia da Internet”. Entre os participantes da comunidade, há convenções adotadas sem que haja explicitação da regra, como abreviações para evitar que determinadas palavras sirvam de estímulo para novas recaídas. As palavras "pornografia", "masturbação" ou "orgasmo", por exemplo, são abreviadas pela inicial em maiúsculo. No comentário feito por Alexandretj no meu post de abertura, foi usado esse tipo de abreviação.

"Seja bem-vindo brFreedom.

Que bom que sua tese é sobre a P. Precisamos alertar todos sobre esse male que é tratado como "normal" - e que se a gente rejeitar ver um vídeo $\mathbf{P}$, podemos ser vitimas de preconceito. Foque na destruição que a $\mathbf{P}$ está causando psicologicamente e afetivamente na vida das pessoas." (Alexandretj, moderador, Para entender a comunidade)

A comunidade reserva o direito de proibir nos posts a menção a endereços de redes sociais externas à comunidade (ex.: Whatsapp ou Facebook) e a troca de e-mails e telefones entre os participantes, sem autorização prévia, pois, segundo eles, isso poderia colocar em risco o anonimato dos participantes.

Homens heterossexuais são a maior parte dos que buscam ajuda na comunidade. São separados em quatro faixas etárias: menores de 20 anos (adolescentes), 20-24, 25-29, 30 ou mais. Eles representam 88,46\% do total de 
mensagens trocadas em toda a comunidade. Há subtópicos para mulheres e para homossexuais, que não fazem distinção de idade, pois são vistos como grupos de interesse onde a idade pouco importa. Há também seções que separam grupos por assunto específico: namorada (o) de alguém dependente, histórias de sucesso, dúvidas gerais sobre a dependência e sugestões de softwares que ajudam a controlar o consumo compulsivo de pornografia on-line (ex.: bloqueadores de acesso). Essa divisão colaborou para a delimitação de tópicos do fórum que seriam incluídos ou excluídos do exame netnográfico na coleta de dados.

Ao entrar para a comunidade, o participante é estimulado a adotar um padrão de comportamento que favoreça sua recuperação. Não há psiquiatras, psicólogos ou especialistas que deem assistência, ou sejam membros da comunidade, por isso o primeiro passo recomendado pelo fórum é a leitura do $e$-book "Método Como Parar", disponível gratuitamente no site. Este material esclarece os principais pontos em relação à compulsão, colaborando para que o participante perceba que está dependente de pornografia on-line; e fornece, durante a explicação, todas as abreviações e termos técnicos que serão vastamente utilizados na comunidade (ex. HOCD, PMO, reboot, gatilho, flatline, efeito caçador etc). Em seguida, no post inicial, o dependente conta sua história e faz deste local um diário, que será atualizado constantemente a cada avanço ou queda na recuperação da compulsão: em troca o participante receberá palavras de incentivo e sugestões para vencer as dificuldades. Cada diário conta todo o itinerário, desde o primeiro contato com a pornografia até a compulsão, similar à forma adotada por Hirschman (1992) em seu estudo, ao solicitar aos entrevistados que "começassem pelo começo" (p. 161). 
Cada indivíduo escolhe para si uma meta de reboot (restaurar o cérebro por meio da abstinência), com tempo e forma. Quanto à forma, há três tipos: Reboot Hardmode - sem sexo, sem masturbação e sem pornografia; Reboot normal - ficar sem masturbação e sem pornografia, mas continuar tendo relações sexuais; Reboot sem pornografia - não se consome pornografia, mas podem ser mantidos a masturbação e o sexo, a fim de, segundo alguns participantes, evitar retenção seminal. A meta de abstinência da pornografia on-line pode ser mais ou menos espaçada. Alguns optam por ficar seis meses sem consumir, outros entendem que esta meta é inexequível e optam por dividi-la em partes, como 15, 25 ou 30 dias sem consumir. A meta é acompanhada com auxílio de um contador associado ao perfil do usuário, que mede o tempo de afastamento de PMO (pornografia, masturbação e orgasmo), reiniciado a cada recaída. O contador é visível para todos os demais participantes, que podem motivar e acompanhar o progresso de cada dependente, por meio do contador e dos relatos de quem tenta recuperar-se da compulsão.

Os vínculos intelectuais e relacionais desenvolvem-se com naturalidade em grupos de apoio virtuais (VROMAN; KOVACICH, 2002). Principalmente em condições de grande ansiedade e de incerteza, o anonimato e a acessibilidade das comunidades permitem mais chances de recuperação, porque reduzem o estresse, melhoram a autoestima e possibilitam o compartilhamento de informações (DAVISON et al., 2000).

A experiência prévia do pesquisador com o campo de estudo pode ser útil para compreender o objeto de pesquisa (GADAMER, 1989). Hirschman (1992), por ser uma dependente em processo de recuperação, estava em situação 
privilegiada ao entrevistar dependentes e participar de grupos de foco. Este contato com um mundo que lhe era familiar possibilitou compreender com mais profundidade os relatos dos consumidores compulsivos. Eu tive problemas com consumo de pornografia on-line, o que me permitiu entender melhor o contexto e interpretar as respostas dos participantes do fórum (comunidade on-line).

\subsubsection{Entrada na comunidade}

Para o post de entrada na comunidade, seis medidas foram tomadas para ter aceitação do público: 1) coloquei-me como quem já teve problema com consumo de pornografia, para gerar identificação; 2) solicitei a intervenção do proprietário do Como Parar para que a pesquisa fosse vista com credibilidade e seriedade pelos membros do fórum; 3) seguindo a estratégia de Scaraboto (2006), utilizei o mesmo título para o post inicial "Para entender a comunidade" e linguagem e terminologia próprias do grupo; 4) reiterei que, mesmo sendo uma comunidade pública e aberta, o anonimato seria garantido para todos; 5) Kozinets (2015) avalia que o uso de smiles durante o texto ajuda a criar empatia com os participantes, o que foi seguido; 6) informei que o estudo será disponibilizado para acesso de todos.

É objeto de debate entre acadêmicos se o pesquisador deve ou não revelar sua identidade. Os defensores da exposição do pesquisador acreditam que, mesmo que os dados sejam públicos e a identidade dos membros seja preservada, por apelido e avatares, os participantes têm o direito de saber que seus dados serão utilizados (BOELLSTORFF et al., 2012) para fins de pesquisa e assim deve ser feito (KOZINETS, 2015; BOWLER JR, 2010). Outros acreditam que revelar a identidade compromete a imparcialidade dos participantes (RAGEH et al., 2013; JANTA, 2011). Como na pesquisa netnográfica a confiança é fundamental e chave 
para seu sucesso (KOZINETS, 2010), optei por revelar a identidade do pesquisador. Daymon e Holloway (2011) explicam que a “confiança é construída pelo envolvimento do pesquisador com os participantes desde o primeiro contato" ( $p$. 236).

Minha identidade foi revelada junto com uma fotografia, nome e a que instituição estava vinculado (PUC-Rio). Expus minha dificuldade em lidar com abstinência em pornografia on-line e que entendia a situação deles. Essas informações francas contribuíram para o envolvimento dos participantes no estudo. Assim como na etnografia, a netnografia necessita da aceitação do pesquisador no grupo social que lhe é estranho (KOZINETS, 2015). Acredito que não teria o mesmo nível de atenção se permanecesse no anonimato ou teria apoio do fundador da comunidade (BOELLSTORFF et al., 2012). No post inicial (anexo 1) foram aplicadas todas as premissas elencadas acima.

Como a comunidade tem grande quantidade de posts e comentários, seria inviável conseguir o consentimento de todos (OSMAN et al., 2014; GOULDING et al., 2013). Não é necessário que haja adesão de inúmeros participantes e ter dezenas de comentários solícitos no post inicial, contanto que os poucos que comentassem não tivessem objeções claras à pesquisa e que houvesse aprovação do proprietário do fórum (SCARABOTO, 2006).

Nas primeiras 24 horas, houve três respostas positivas de usuários com tempo significativo de experiência, colocando-se à disposição para ajudar respondendo a algum questionário ou se oferecendo para entrevista. Todos entenderam a relevância da pesquisa. Kozinets (2015) também defende que, por questões de ética, deve-se sempre lembrar os participantes da finalidade da 
interação. Para evitar que a todo tempo precisasse lembrá-los nos posts, a solução encontrada foi colocar como "assinatura do perfil", texto que vai imediatamente abaixo dos posts, o motivo de estar naquela comunidade, que dizia: "sou aluno de doutorado da PUC-Rio e estou escrevendo minha tese sobre pornografia. Estou aqui para compreender cada vez mais esse problema que prejudicou minha vida e de todos que estão aqui”. Ao final da pesquisa, no post de entrada havia 22 comentários e 1288 visualizações o post.

A observação participante ocorreu junto ao processo de coleta e análise de dados. Kozinets (2015) separa as três últimas etapas como passos diferentes, mas que devem ser executados ao mesmo tempo. Ele recomenda que a netnografia seja orgânica e simultânea.

\subsubsection{Coleta de dados}

A diferença da netnografia em relação a qualquer outra coleta, codificação ou interpretação de dados on-line, é sua abordagem participativa na comunidade/grupo de suporte (KOZINETS, 2014). Diferentemente do que ocorre em estudos on-line em comunidade, os dados emergiram da comunidade a partir de envolvimento, engajamento, contato, interação, comunhão, relação, colaboração e conexão com membros da comunidade (KOZINETS, 2014), assim "a participação do pesquisador no grupo ou na comunidade é inegociável”, pois, o “download dos textos, mineração dos dados e navegação pela comunidade são insuficientes" (KOZINETS, 2014, p. 243).

A coleta forneceu três tipos de dados: 1) arquivais, quando não participei do diário, mas que serviram ao objetivo de pesquisa; 2) extraídos, criados a partir da minha interação no diário (fazendo pergunta e obtendo resposta ou dando incentivo 
à recuperação); 3) notas de campo, anotações feitas em arquivo de texto durante o processo de coleta e análise, para ajudar na interpretação. Como na netnografia não há interação visual, as notas de campo e as interpretações dos relatos ficaram restritos a descrições a respeito de estados emocionais, ou representados por meio de smiles (KOZINETS, 2015).

Os posts selecionados para a investigação netnográfica estão em duas das três seções mais movimentadas do fórum, com participantes na faixa etária entre 20 e 29 anos de idade (59,33\% da comunidade), nas seções Como Parar, em posts escritos por homens heterossexuais com "idade de 20 a 24" e "idade de 25 a 29". Este recorte é significativo quando comparado com a distribuição de consumidores de pornografia on-line no Brasil: $43 \%$ têm de 18 a 25 anos e $28 \%$ entre 25 a 34 anos (CUMINALE, 2016). Não se sabe seu o nível escolar, sua profissão ou quaisquer aspectos que sejam uniformes a ponto de serem classificados. Os únicos dados disponíveis e verificáveis são a idade (ou faixa) e sexo.

Seguindo Kozinets (2010), os trechos retirados da comunidade on-line foram considerados na íntegra, sem qualquer correção gramatical ou sintática. Nos casos onde o relato estendeu-se demasiadamente, ou quando o participante utilizou palavras de baixo calão, houve cortes e quebra de trechos sem prejuízo do significado. Optou-se também por grifar com negrito as partes que tratam especificamente do tema interpretado para que não se misturasse ao contexto. As citações ao longo de toda a análise estão vinculadas a um dos vinte diários com os quais interagi (Quadro 3). 
Quadro 3 - Lista de diários, separados por faixa etária (dez/ 2019)

\begin{tabular}{llrr} 
Diários de 20 a 24 anos & Pseudônimo & Mensagens & Visualizações \\
\hline Arqueiro de Jesus & Arqueiro de Jesus & 855 & 12.673 \\
Diário do Rivera & Rivera & 230 & 6.455 \\
Diário do Coyote & Coyotestrong & 367 & 10.823 \\
Diário do Mr_reboot & Mr_reboot & 529 & 11.355 \\
Diário-Randy & Randy & 711 & 11.560 \\
Diario - IllidaN & Illiadan & 407 & 10.397 \\
Diário do CN & Capitão Nascimento & 292 & 10.009 \\
Diário do Joseph & Joseph & 656 & 11.922 \\
Diário do Vegeta & Vegeta & 639 & 11.310 \\
Diário do Kuroro & Kuroro & 321 & 10.085 \\
\hline & & & \\
Diários de 25 a 29 anos & Pseudônimo & Mensagens & Visualizações \\
\hline Diário do Rottweiler & Rottweiler & 231 & 7.577 \\
Diario do fc1992 & fc1992 & 238 & 7.991 \\
Diário - Vierkenes & Vierkenes & 608 & 13.239 \\
Diário de Vencedor1989 & Vencedor1989 & 519 & 11.368 \\
Diário do Wildwarrior & Wildwarrior & 272 & 8.040 \\
Diário do Potiguar & Potiguar & 642 & 10.945 \\
Diario de um viciado em crise & Kusmin & 228 & 7.322 \\
Diário do Seeker & Seeker & 626 & 10.999 \\
Diário do Campeão do Mundo & Campeão do mundo & 396 & 10.526 \\
Diário do Headbanger & Headbanger & 320 & 10.411 \\
\hline
\end{tabular}

Além desses 20 diários com que interagi, foram coletados dados arquivais dos mesmos grupos (20 a 29 anos), referente a outras discussões que serviram para reforçar as categorias encontradas (Quadro 6).

O recorte feito não incluiu pessoas do sexo feminino por três razões: o comportamento de consumo feminino difere significativamente do masculino; haveria dificuldade em entrevistar mulheres, uma vez que o pesquisador é do sexo masculino; mulheres representavam na comunidade Como Parar menos de 1,34\% das interações até abril de 2019. Contudo, este número pode aumentar nos próximos anos e pode servir a pesquisas futuras. Boies (2002) descobriu que, 
proporcionalmente, o consumo de pornografia on-line é maior entre mulheres mais novas ( $25 \%$ do total) do que entre mulheres de mais idade $(14,28 \%$ do total).

$\mathrm{Na}$ coleta e análise, Wolcott (1994) nomeou assim as categorias de informação: assistir, perguntar e examinar. Já Miles e Huberman (1994) entendemnas como documentos, entrevistas e observações. No geral, eles consideram três formas de coletar os dados: a primeira, onde não há participação; a segunda, com alguma interação; e a terceira, utilizando alguma abordagem interpretativista dos dados.

Para a extração dos dados, foram escolhidos os 10 diários com mais interações no primeiro mês de imersão, em cada um dos dois grupos (idade de 20 a 24 e idade de 25 a 29). Os diários selecionados foram escritos por homens que se definem como heterossexuais (sexo), dependentes em pornografia on-line (formato). O critério de seleção também considerou diários mais atuais e que tivessem acima de 200 comentários (engajamento). Foram lidas, analisadas e interagidas 9.087 mensagens, somando 205.007 visualizações, até novembro 2019.

Durante a imersão, busquei o que Kozinets (1994) entende como essencial: absorver a cultura, ganhar senso de pertencimento, fazer perguntas e obter respostas, assumir papéis de incentivo aos dependentes com o objetivo de encontrar um fio condutor em todas narrativas e histórias de vida. Não foi feita qualquer adaptação no texto dos comentários nos posts, sendo extraídos inclusive com erros gramaticais, gírias e abreviações (KOZINETS, 2014). Por ser uma comunidade brasileira, não foi necessário qualquer ajuste textual ou tradução. Ao interpretar as interações, não foram feitas acepções de palavras entre compulsão, obsessão ou dependência, ao falar do consumo compulsivo de pornografia on-line, pois os 
participantes tendem a não abordar o tema com rigor científico e, portanto, são incapazes de perceber distinções entre termos.

\subsubsection{Análise, interpretação e reinterpretação dos dados}

Segundo, Mkono (2012), existem inúmeras formas de analisar os dados qualitativamente: "para ser mais preciso, a netnografia é a combinação de vários métodos e técnicas que podem incluir análise de conteúdo, análise histórica, semiótica, hermenêutica, análise de narrativas, análise de temas e outros" (MKONO, 2012, p. 389).

Como se trata de "interpretar realidades complexas que não se limitam a esquemas fechados" (TAROZZI, 2011, p. 21), a perspectiva da interpretação hermenêutica foi adotada, uma vez que se busca a compreensão de significados de experiências do indivíduo e como esses interpretam o mundo a sua volta (CRESWELL, 2003) a partir de sua percepção sobre o fenômeno investigado (THOMPSON et al., 1990).

Kozinets (2015) recomenda analisar as mensagens de acordo com o envolvimento de cada indivíduo na comunidade. Isto é facilmente verificável na comunidade Como Parar, porque, abaixo do avatar (imagem), há sempre a quantidade de mensagens que o usuário já escreveu (engajamento) e a sua data de entrada na comunidade.

Pode-se distinguir, assim, um post de alguém que acabou de entrar na comunidade com os escritos por usuários mais experientes (devotos). Em geral, o "tipo de participante" foi classificado em quatro níveis de engajamento: 
principiantes, socializadores, devotos e confidentes, cada qual separado por status a partir do número de comentários na comunidade (status $=\left[n^{\circ}\right.$ de comentários $]$ ).

Quadro 4 - Status de cada participante do fórum.

\begin{tabular}{|l|l|}
\hline \multicolumn{1}{|c|}{ Tipo de Participante } & Quantidade de mensagens \\
\hline Principiantes & Até 100 \\
\hline Socializadores & Entre 101 e 200 \\
\hline Devotos & Entre 201 e 400 \\
\hline Confidentes & Acima de 400 \\
\hline
\end{tabular}

Não só a quantidade de comentários e interações são importantes indicadores; o relacionamento de cada participante pode variar de intensamente pessoal e profundamente significativo até superficial, de curta duração e relativamente insignificante (KOZINETS, 2014).

Nessa comunidade, existem "moderadores", indivíduos com quantidade de mensagens bem acima do nível "devoto", elevados a esse status para ajudar o administrador (dono da comunidade) a controlar as violações de regras, bem como para incentivar e ajudar os participantes com sugestões. Geralmente são indivíduos que participaram da comunidade como dependentes, mas que estão há mais de 180 dias sem consumir, de modo que sua compulsão é considerada por eles próprios como controlada.

Os comentários extraídos para análise foram referenciados com dois dados relativos à fonte: "nome do autor" e "nível de participação". Quando o comentário feito não do proprietário do diário, coloca-se também o "nome do diário onde houve o comentário", e, nas formas abreviadas durante o texto corrido, somente o " nome do autor". 
Para Scaraboto (2006), os dados principais do comentador eram o título do comentário, a data e a hora em que foram realizados, uma vez que se tratava de uma comunidade de mulheres grávidas e, portanto, fazia-se necessário saber as datas para conhecer o tempo de gestação de cada uma.

Já no estudo de Thanh e Kirova (2018), em uma comunidade on-line sobre turismo de vinhos, os dados do usuário foram apenas nome e data do comentário. Neste estudo, o importante foi saber o nível de participação e se o autor do comentário era o mesmo do diário. Houve também o critério de adequação ou não ao objetivo. Comentários que não eram do interesse de pesquisa foram descartados. Filtrar as informações relevantes tornou-se tarefa essencial devido à quantidade de mensagens disponíveis e o recorte feito em apenas 20 diários.

Os dados extraídos foram categorizados, os trechos foram organizados em dois grupos que emergiram dos relatos: antecedentes do consumo compulsivo e consequências percebidas pelos membros da comunidade. A categorização foi inspirada na revisão de literatura de consumo compulsivo e em minha experiência pessoal.

Dentro de cada categoria, havia temas que são conjuntos de consequências identificadas nos relatos e em certos casos encontrados na literatura. A categoria “problemas pessoais e profissionais", por exemplo, agrupou os temas "viver vida dupla", "redução do interesse na parceira", "procrastinação no estudo e no trabalho", "dificuldade de gerenciar a própria vida". Em cada um dos temas, há unidades de sentido que o formam: para "viver uma vida dupla" há unidades de sentido como "esconder o consumo das pessoas" e "reforço positivo para fugir da dor e buscar o prazer". Como a maioria dos novos participantes leem um mesmo $e$ - 
book e visitam outros diários para sanar dúvidas, ao compor a própria história tendem a descrever o que sentem usando categorias, temas e unidades de sentido semelhantes, provavelmente porque todos os usuários leram um mesmo e-book (que esclarece sobre aspectos básicos da compulsão em pornografia on-line) ao entrar para a comunidade.

\subsection{Segunda fase - Entrevistas}

As entrevistas foram utilizadas como complemento à netnografia, permitindo alargar a compreensão do que foi observado a partir dos relatos na comunidade (KOZINETS, 2014). A netnografia permitiu reconhecer, por meio da interação e imersão na comunidade, possíveis consequências e antecedentes do consumo compulsivo de pornografia on-line.

Explica Kozinets (2015) que a adesão do líder aumenta a confiabilidade dos participantes do fórum no pesquisador. Portanto, para conduzir as entrevistas, solicitei ao proprietário do fórum que ajudasse a buscar voluntários para a pesquisa dentro da comunidade, que postou um anúncio global que atingiu, em algumas semanas, mais de dez mil visualizações e 33 interações por mensagem (Anexo 2). Selecionei 15 voluntários, de acordo com a ordem de mensagens recebidas, dentro da faixa de idade e todos homens heterossexuais.

Tendo recebido muitos e-mails de pessoas querendo colaborar, fiz uma primeira seleção de entrevistas com quatro pessoas, para compreender o que poderia encontrar. Algumas foram descartadas por não terem o perfil esperado (por exemplo, um adolescente de 16 anos que se declara homossexual). Foi notado também, depois de algumas entrevistas, que outras faixas etárias seriam interessantes para permitir melhor compreensão de consequências que só viriam 
com mais idade, como a "infidelidade virtual”. Por isso, busquei indivíduos com mais de 30 anos. Segundo Hirschman (1992), a maior diversidade entre os participantes na hora de entrevistar enriquece o estudo, uma vez que é possível observar se os temas aparecem independente das características individuais.

Todos os voluntários para as entrevistas tinham experiência de, pelo menos, 7 anos praticando PMO na Internet, quase todos os dias. Em alguns casos, como Rodion Romanovich e Zorro Selvagem, o consumo de pornografia e de masturbação era superior a 20 anos. Leonidas foi o mais jovem entrevistado, com 18 anos, mas masturbava-se desde os 11 . Todos têm diário no fórum e interagem com os demais participantes. Rosseaustrong é um dos mais antigos usuários, tendo começado a participar em agosto de 2017. As perguntas sobre ocupação, idade, formação e "com quem reside" me ajudaram a perceber, entre outras coisas, que ócio e solidão parecem ser gatilhos para fantasias (DE BRUIJN et al., 2006), bem como a inferir outros aspectos do contexto do consumidor que podem influenciar sua compulsão. Como será discutido, a idade está diretamente relacionada a que tipo de consumo o indivíduo começou sua compulsão. Enquanto os mais jovens já nasceram em um ambiente de pornografia on-line, os mais velhos começaram com revistas e fitas VHS.

Não foram utilizados os mesmos critérios de escolha dos diários para a escolha dos entrevistados. Enquanto estes foram por conveniência de acordo com a disponibilidade de cada voluntário para participar e sua adequação ao escopo da pesquisa, aqueles foram pela relevância e atualidade (KOZINETS, 2015). Como a faixa de idade é relativamente baixa, não houve muitos casos de pessoas casadas e, portanto, optei por trocar o campo de "estado civil" para "relacionamento", 
separando o grupo dos que têm ou não têm namorada, uma vez que a maioria dos membros com que interagi considera normal ter relações sexuais antes do casamento. O perfil dos entrevistados e os temas recorrentes são apresentados no Quadro 5. 
Quadro 5 - Perfil dos entrevistados e temas recorrentes

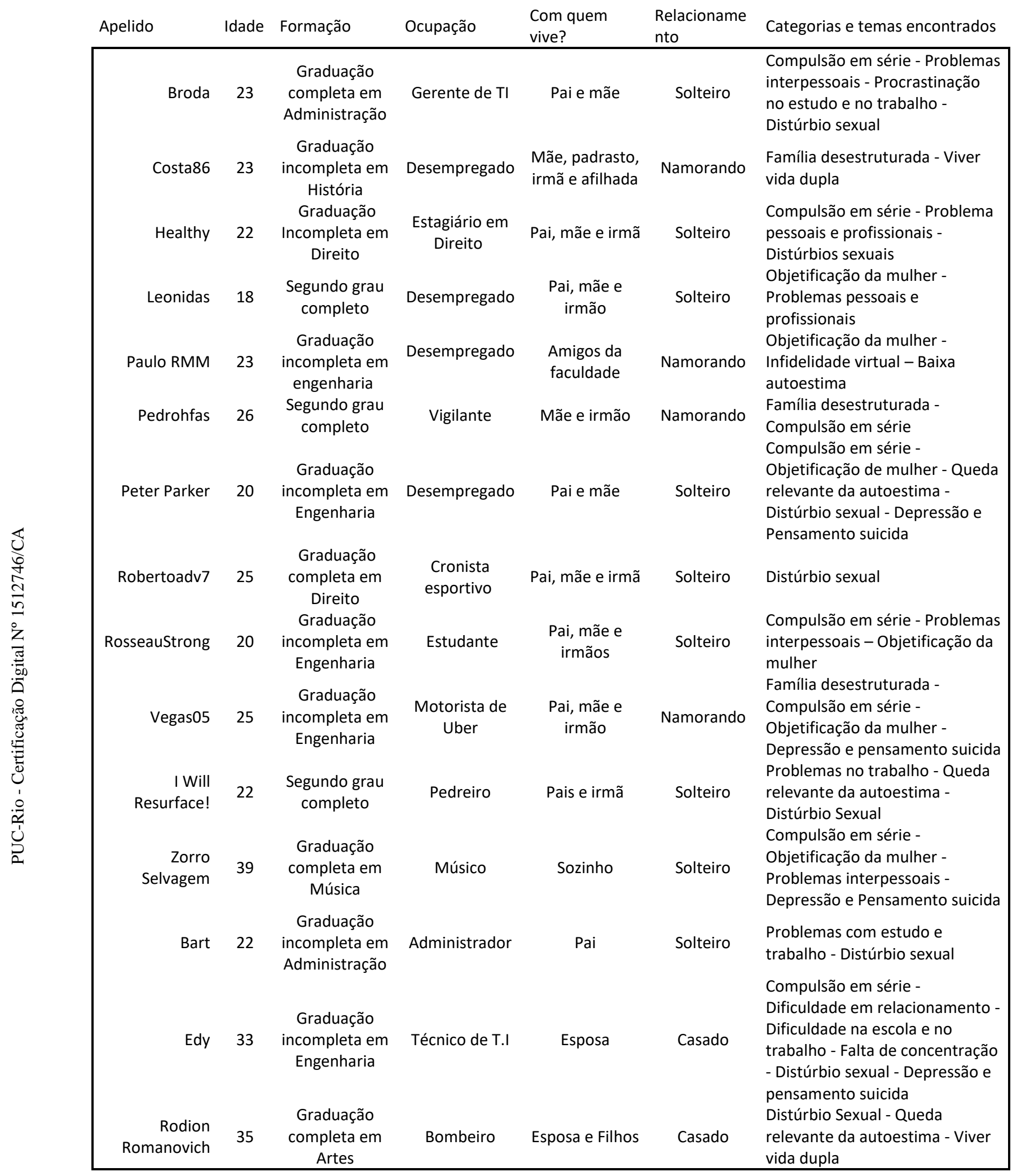


As entrevistas não foram conduzidas on-line porque, ao estabelecer o primeiro contato com os usuários, eles disseram ter dificuldades para uma conversa com privacidade diante do computador, preferindo ser entrevistados por telefone celular, assim podendo falar da rua ou afastados de outras pessoas. Falar sobre o assunto na presença de outras pessoas, segundo eles, traz considerável constrangimento e impossibilitaria a entrevista.

Aos que aceitaram colaborar, foi solicitado que dessem assentimento por email ao termo de consentimento livre e esclarecido (TCLE), aprovado pelo comitê de ética da PUC-Rio. O áudio da entrevista serviu somente para uso na tese e foi por mim transcrito, sem interferência de terceiros. Todos os dados foram armazenados em disco externo e serão mantidos por quatro anos.

A primeira e principal solicitação feita ao entrevistado foi: "Você pode contar sua história, desde quando começou a consumir pornografia on-line até hoje?", mesma pergunta utilizada por Hirschman (1992) em seu estudo. Thompson, Locander e Pollio (1989) defendem este tipo de abordagem, para casos em que se tenta entender a maneira como indivíduos percebem sua vida e o contexto à sua volta.

Na entrevista fenomenológica (THOMPSON et al., 1989), as perguntas subsequentes dependem exclusivamente do que for dito pelo entrevistado, que conduz todo o processo. As questões devem surgir durante a entrevista e não serem pré-estabelecidas. Intervenções com perguntas abertas foram feitas durante a conversa, para explorar melhor o que havia sido dito, como: "Como você se sentia?", "Você poderia me falar mais sobre isso?"; “Como isso se desenvolveu?", 
“Que tipo de consequência você atribui ao que disse agora?" e "Em que sentido essa consequência o atrapalha?".

\subsection{Análise hermenêutica}

Na perspectiva hermenêutica, as histórias contadas sobre experiências com produtos ou serviços dizem muito sobre comportamento (THOMPSON et al., 1997) e nesse ponto reside a relevância para o campo de marketing, uma vez que "profissionais de marketing buscam modelos que os auxilie a analisar e interpretar como os consumidores se relacionam com produtos" (WALKER; OLSON, 1991, p. 111).

A abordagem interpretativista, assumida neste estudo, busca a "compreensão de como os consumidores se veem e experimentam o mundo" (MCCRACKEN, 1988, p. 12). Quando o pesquisador, carregado de preconceitos e prejulgamentos, confronta a sua visão de mundo com os dados da realidade que emergem na interação netnográfica, é levado a rever conceitos e estabelecer nova visão a respeito do fenômeno investigado (ARNOLD; FISCHER, 1994; GADAMER, 1975). Esta abordagem será insuficiente se seus conceitos permanecerem os mesmos após evidências em contrário, mas será positiva na medida em que o estranhamento - efeito próprio do método netnográfico que leva o pesquisador a repensar seus conceitos - levá-lo a melhor compreender o problema (ARNOLD; FISCHER, 1994).

Arnold e Fischer (1994) desenvolvem a noção da parte e do todo na interpretação indutiva dos dados: "o significado de um texto inteiro é determinado a partir dos elementos individuais do texto, ao passo que o elemento individual é compreendido por referência ao todo do qual faz parte. Elementos específicos são 
examinados repetidas vezes, cada vez com uma concepção ligeiramente diferente do todo global. Gradualmente, uma descrição cada vez mais integrada e abrangente dos elementos específicos, bem como do texto como um todo, emerge" (ARNOLD; FISCHER, 1994, p. 63).

Esses movimentos interativo e iterativo são realizados até que se entenda o objeto sem qualquer contradição (ARNOLD; FISCHER, 1994; GADAMER, 1989). Interativo porque minha proximidade como observador não-participante por nove meses, e depois como pesquisador na comunidade on-line por mais nove meses, eivado de ideias e teorias aprioristicamente concebidas, que foram projetadas no relacionamento com os participantes do grupo; iterativa, porque, através do significado estrutural recebido, alterei minha visão anterior a partir do campo (Figura 1).

Figura 01 - A Fusão de Horizontes (traduzido de Thompson et al., 1994, p. 434)

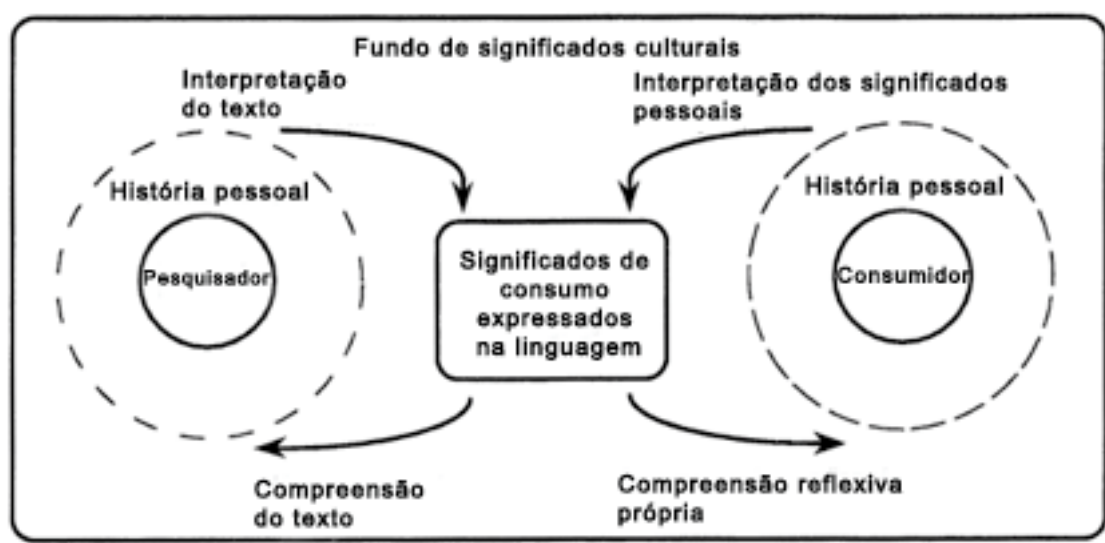

Tanto a netnografia quanto as entrevistas permitiram que houvesse troca de significados entre mim e os consumidores compulsivos na comunidade on-line durante alguns meses. Esse processo permite que o consumidor reflita os significados e aumente a compreensão de suas experiências passadas, ao mesmo tempo em que o pesquisador tenta interpretar e compreender os mesmos 
significados a partir da visão do consumidor, expressos em sua linguagem (THOMPSON et al., 1994).

A interpretação hermenêutica busca interpretações que sejam (ARNOLD; FISCHER, 1994):

- Coerentes e livres de contradição;

- Compreensíveis para o público leitor;

- Respaldadas com exemplos;

- Escritas em linguagem persuasiva e envolvente;

- Relacionadas a literatura do objeto de pesquisa;

- Que produzam insights, capazes de revisar o atual entendimento sobre o tema. 
4.

\section{Análise e discussão}

Este capítulo está separando em duas partes: a primeira será feita análise dos relatos com base na netnografia realizada por nove meses na comunidade Como Parar. Na segunda parte me deterei a analisar as vinte entrevistas realizadas com participantes com diferentes perfis da comunidade.

\subsection{Relatos dos diários}

Quase a totalidade dos dados coletados no fórum foram extraídos dos 20 diários com que interagi. Logo, toda menção aos "relatos" ou "diários da comunidade" refere-se a posts onde me passei por participante e pesquisador, não da comunidade como um todo. Os dados do tipo "arquivais", isto é, com que não houve interação, são descritos com a legenda "dados arquivais". Para evitar repetições, quando a citação é feita pelo proprietário do diário, omiti o nome do diário, restringindo-me somente ao nome do consumidor. Optei por usar o recurso de negrito nas citações, para destacar trechos que dizem respeito à discussão empenhada.

\subsubsection{Antecedentes do consumo compulsivo}

Embora muitos consumidores compulsivos de pornografia on-line não reconheçam que a prática possa causar danos à saúde ou ao bem-estar, há os que a associem a consequências indesejáveis e buscam ajuda em fóruns on-line. (TAYLOR; JACKSON, 2018; CAVAGLION, 2009). Nascidos entre 1990 e 1999, os membros da comunidade com que interagi, com idades de 20 a 29 anos, eram pré-adolescentes quando começaram a ter contato com a Internet. Muitos 
mencionaram que seu primeiro contato com pornografia foi através de revistas e de filmes em DVD ou VHS, geralmente apresentados por algum parente ou amigo. Mais tarde, o anonimato, a acessibilidade e a quantidade de material gratuito disponível na Internet fizeram com que criassem hábito mais frequente de consumo (como também foi constatado por YOUNG, 2008; BOSTWICK; BREW, 2008; GRIFFITHS, 2000). Por falta de informação, o adolescente, estimulado pela curiosidade, acessa sites, vídeos e fotos pornográficos que o introduzem ao ciclo compulsivo (GARLICK, 2011). Alexandre17 é um exemplo:

“conheci a pornografia com mais ou menos 11 anos (...) porem na época eu não poderia pegar em uma locadora pois era muito novo além da vergonha de alguém em minha casa descobrir. (...) Entretanto o que já era ruim acabou piorando quando aos 14 anos passei a ter acesso a internet em casa, eu comecei a me afundar mais e mais nesse vicio pois bastava me trancar no quarto, eu não precisaria mais ter que pedir dvd emprestado a alguém. todos os dias eu sentia necessidade de consumir pornografia" (Alexandre17, confidente, Diário do Vegeta)

As gratificações imediatas advindas do consumo de pornografia on-line, como prazer e redução de emoções negativas, associadas ao desconhecimento sobre riscos de longo prazo envolvidos (KOHUT et al., 2017; MCCRACKEN, 1988), e a curiosidade parecem atrair os consumidores (PAUL; SHIM, 2008). Mais tarde, ao perceber consequências em sua vida, tentam interromper o consumo, mas sentem que não conseguem (LOVE et al., 2015). O diário de Brainbuilder é simbólico: seu consumo começou aos nove anos e os problemas que caracterizam o consumo compulsivo só foram percebidos catorze anos depois:

"Tenho 23 anos de idade. A primeira vez que tive contato com pornografia foi aos 9 anos de idade. Fitas VHS do tio, vi escondido, com meus irmãos. A coisa começou a tomar força anos mais tarde, com 13 anos, quando a internet ganhava espaço na minha casa. A partir de então, passei gradativamente a ver pornografia cada vez mais regularmente, até se transformar em uma rotina diária de 30 a 60 minutos. (...) Até pouco tempo atrás não havia percebido o quanto isso estava me fazendo mal. Pra ser específico, até Fevereiro deste ano" (Brainbuilder, socializador) 
Neste ponto, parece ocorrer o que Hirschman (1992) distinguiu como "traços da personalidade", isto é, características individuais aprendidas ou genéticas que predispõe o indivíduo a ter um padrão de consumo. Cavaglion (2009) distinguiu os consumidores entre que estão em "processo de desenvolvimento" da compulsão e os que vivem "vida dupla", que sofreram algum trauma no passado ou no presente e buscam a pornografia para substituir o mundo real e traumático pelo virtual e prazeroso. Demonilco (2002) chamou esse grupo de "predispostos", dado o histórico de instabilidade emocional por que passam e que abre caminho para a compulsão.

Nos casos com que tive contato, também foi possível perceber dois padrões de antecedentes da compulsão na pré-adolescência: os que começaram a consumir por curiosidade, prazer e diversão e os que buscaram o consumo em decorrência de abusos sexuais, desestrutura familiar ou por ser um dos pais consumidor de drogas. Esse começo parece impactar o consumo a posteriori, porque diz respeito ao ambiente onde ocorre a formação emocional do indivíduo. Os dois grupos começam a se dar conta das consequências negativas cerca de dez a quinze anos após o início do consumo, geralmente quando concluem que alguns problemas de sua vida só podem ter origem no consumo de pornografia on-line.

O grupo com histórico de consumo ligado ao prazer e a entretenimento parece ser baseado no condicionamento operante (SKINNER, 2003; ELHAI et al., 2017; ROBINSON; BERRIDGE, 2001) e na teoria de aprendizagem (HOCH; LOWESTEIN, 1991). Buscam estímulos que dão prazer e satisfação ao mesmo tempo que este ciclo "negativo-positivo-negativo" os fazem aprender a depender do estímulo (SARANEVA; SAAKSJARVI, 2008). A chegada da Internet trouxe 
liberdade para obter reforços positivos irrestritamente. Não há mais barreiras, pois "bastava me trancar no quarto, que eu não precisaria mais ter que pedir DVD emprestado a alguém" (Vegeta, em seu diário). Em decorrência de anos condicionando o cérebro a estímulos sexuais, associam o consumo à dificuldade em se relacionar com mulheres, baixa autoestima, solidão e outros sentimentos negativos. A maioria tem problemas ligados ao ambiente de trabalho e a estudos, alegando que a pornografia on-line os leva à procrastinação de tarefas e à negligência nas atividades acadêmicas, temas que tratarei mais a frente detidamente.

\begin{abstract}
"Como muitos aqui, eu comecei a me masturbar com 11 anos e a ver pornografia com 12. No início, era muito bom, tinha várias ereções. Era normal chegar da escola e correr para o banheiro e me masturbar pensando na professora, nas colegas de turmas ou vendo uma revista playboy. Logo depois, descobri a pornografia na internet e começava a entrar nos sites pornográficos. Mas tudo se acentuou com 17 anos quando passei a ter internet banda larga no quarto. $\mathbf{E}$ aí comecei a baixar pornografia sem parar" (Randy, confidente)
\end{abstract}

O segundo grupo difere por traumas na pré-adolescência, à época do início do consumo da pornografia on-line, ocasionados por abuso sexual, desestrutura familiar ou problemas emocionais durante a infância. O estímulo visual, obtido online, e a masturbação seriam a "válvula de escape disso tudo" (Trent, em seu diário). A pornografia on-line parece ser um anestésico dos problemas reais, percebida como forma de lidar através do esquecimento das dificuldades por meio da busca do prazer (BAKER et al., 2004).

Experiências negativas durante a infância parecem colaborar para o desenvolvimento de alguns distúrbios sexuais (i.e. abuso sexual), considerados por alguns integrantes da comunidade como mais graves, ao ponto de sentirem "vergonha de falar" (Kuroro em seu diário). É possível identificar membros com 
práticas de HOCD (heterossexuais que desejam conteúdo homossexual), froteurismo (desejo de encostar a genitália nas mulheres em local público), pedofilia, zoofilia e desejos diversos, que serão mais à frente tratados como consequências.

\begin{abstract}
"Tive contato com pornografia muito cedo por conta do meu irmão mais velho, e na adolescência me afoguei em Pornografia e masturbação, muito por causa dos meus problemas em casa. Meus pais vivam brigando, traições, ameaças de morte, então a PMO era a minha válvula de escape disso tudo. Por conta disso tudo desenvolvi muitos transtornos psicológicos, como o próprio HOCD, atualmente estou afogado nisso, só assisto $P$ que vai na direção contraria a minha orientação sexual, é realmente muito frustrante" (Trent, confidente)
\end{abstract}

Eventos relevantes que surgem na vida do indivíduo, como a morte de um parente, mudança de cidade ou admissão na faculdade, e desestrutura do ambiente familiar durante a infância (considerados por Hirschman (1992) como padrões que antecedem a compulsão) estão presentes em alguns relatos, geralmente descritos com emoções negativas, como estresse, infelicidade geral, angústia ou ansiedade.

"eu estava passando por um momento de grande estresse e ansiedade devido ao vestibular, e acabava recorrendo ao PMO para me aliviar e me sentir melhor." (Barão de Montesquieu, confidente, diário de um filósofo - dados arquivais)

O consumidor busca pornografia on-line como "válvula de escape", mas, com o passar do tempo, o consumo compulsivo parece aumentar as emoções negativas, que serão apaziguadas novamente pela recaída. Após o consumo, o alívio a curto prazo acaba e provoca o agravamento dos sintomas ruins que levaram ao consumo inicial.

Três fatores parecem favorecer a recaída dos que foram buscar auxílio na comunidade: 1) local em que o conteúdo é visualizado: em casa, sempre de forma solitária, quando não se tem namorada/esposa; 2) o estado emocional do 
consumidor: tristeza, estresse ou ansiedade, e 3) estímulos ambientais, como músicas, textos eróticos, fotos ou vídeos de mulheres em redes sociais, sites com conteúdo pornográfico e imaginação ou lembrança de vivências passadas.

"Principal problema, portanto é o ócio e o desemprego. Mesmo que eu não tenha um emprego de carteira assinada, preciso arranjar alguma outra função, algo que me faça acordar de manhã e sair de casa, um compromisso, qualquer coisa. É horrível ficar assim. Precisa de muito equilíbrio pra não se jogar nas drogas (ou na P, no nosso caso).” (Vierkess, confidente)

No consumo de pornografia on-line parece haver o padrão de consumo compulsivo em série (HISCHMAN, 1992; YBARRA; MITCHELL, 2005; BRAND et al., 2011). Para Zimbardo e Duncan (2012), jogos on-line podem ser precedentes do consumo de pornografia. Bőthe e colegas (2015) acreditam que "a imersão em jogos on-line está de mãos dadas com a imersão em pornografia on-line” (p. 5). Há indivíduos que não percebem ter compulsões em série e os consomem simultaneamente, ignorando possíveis males (MCCRACKEN, 1988) e considerando somente uma das compulsões como verdadeiramente um problema enquanto os demais são formas de recreação. Embora não tenha sido encontrado qualquer estudo que mostre correlação entre o tempo consumido em jogos e em pornografia, há indícios de que os dois consumos compulsivos possam coexistir na vida do mesmo indivíduo (BÖTHE et al., 2015).

Ainda que a pornografia, os jogos em computador ou os videogames e a Internet tenham potencial para se tornarem atividades compulsivas (LOVE et al., 2015; YOUNG et al., 2010) e possam ser consumidos em série, nem sempre é possível perceber, nos relatos, se alguma compulsão precede outra, nem se foram todas adquiridas simultaneamente (CASTRO-CALVO et al., 2018). Alguns 
comentam que "passam o dia inteiro surfando na Internet" (CoyoteStrong, em seu diário), ou que vivem a vida entre jogos on-line e "PMO".

"Via porno hétero regularmente mas não era bem um viciado, pois era viciado em jogos e ficava até tarde jogando Runescape e não tinha tempo pra isso. Contudo, após um anos, larguei os jogos e mergulhei "de cara" na pornografia. Foi nessa idade que minha vida virou uma verdadeira bagunça" (Henrique1gomez, confidente, Luta contra o HOCD)

É comum haver relatos de indivíduos que conseguem afastar-se do consumo de pornografia hardcore, mas que recaem ao receber estímulos inesperados nas redes sociais onde fotos e vídeos sensuais excitam e levam ao mesmo ciclo de estímulo, masturbação e orgasmo.

"Bloqueei tudo, não tenho acesso ao YouTube, muito menos ao instagram e facebook. Se queremos concluir um reboot, temos um preço a pagar, e esse preço é abdicar de TUDO que nos atrasa ou nos faz recair." (Capitão Nascimento, confidente, Diário do $\mathrm{CN}$ )

As redes sociais parecem servir como estímulo para a masturbação, para jovens que são sensíveis a qualquer estímulo sexual (BAUMGARTNER et al., 2012; BEYENS; EGGERMONT, 2014). Para quem está em processo de recuperação, sites que contém "sexo explícito" parecem ser inadequados. Mas, embora não seja evidente, às vezes redes sociais podem servir para o mesmo fim. É quase unânime na comunidade a ideia de que os sites Facebook, Instagram e Youtube são meios que entregam o softcore porn (pornografia leve) e isso favorece a recaída.

\footnotetext{
"Ontem vi uma mulher de biquini na barra dos status do Whatsapp e automaticamente fiquei excitado mas me controlei e apaguei todos os contatos que lá aparecem." (Rivera, confidente, Diário do Rivera).

"Eu desativei porque essas redes sempre são uma fonte de gatilho e se continuarem abertas uma hora você sempre vai ter vontade de acessá-las." (Blpr, confidente, Diário do Arqueiro de Jesus)
} 


\title{
4.1.2 Consequências percebidas
}

\section{Percepção da compulsão e recaídas}

Os membros da comunidade com quem interagi consideram a percepção da compulsão como marco inicial para buscar auxílio, pois em um determinado momento passaram a associar consequências negativas ao consumo de pornografia on-line (GRUBBS et al., 2015). Essa percepção pode ocorrer de diferentes formas. Passaram a desconfiar quando o consumo de pornografia, embora prazeroso, por diversas vezes os deixaram "se sentindo mal depois de sessões intensas de pornografia" (Rivera, em seu diário), ou quando ocorre algum evento que evidencia a discrepância entre as sensações com o "sexo virtual" e com o sexo real.

\begin{abstract}
"Percebi a gravidade do meu problema quando mesmo com garotas de programa, FALHEI, em outras palavras BROCHEI. Coisa que nunca acontece quando estou consumindo pornografia virtual, de certa forma minha mente está treinada para ser um voyeur" (Coyote, confidente).
\end{abstract}

Em alguns casos, a percepção só vem quando o indivíduo tem contato com algum material que explique por que a pornografia pode gerar compulsão. No fórum, esse caso é comum, porque os que se associam deparam-se com histórias semelhantes à sua e com informações a respeito do consumo excessivo de pornografia.

\footnotetext{
"Tenho 22 anos e conheci esse fórum há duas e foi a melhor coisa que aconteceu comigo neste ano. Fui ler o ebook e confirmei o que já sabia há algum tempo: eu era viciado em pornografia." (Randy, confidente)
}

Quando percebe que é dependente, o consumo compulsivo de pornografia deixa de ser recreação para tornar-se um problema a resolver (GRUBBS et al., 2015). As principais características são a percepção da compulsão, vontade 
incontrolável para acessar e angústia diante da pornografia (BLAIS-LECOURS et al., 2016).

A recaída é inerente a qualquer consumo compulsivo (HIRSCHMAN, 1992; DE OLIVEIRA et al., 2004; O’GUINN; FABER, 1989; GRUBBS et al., 2015). O início do ciclo é sempre a partir de um "gatilho", termo utilizado pelos membros da comunidade como sinal externo ou interno que ativa a imaginação e leva o indivíduo à recaída. Os gatilhos internos são fantasias (imaginação), "efeito caçador" ou "fissura" (forte desejo de voltar ao consumo após uma recaída recente), ou serem considerados "sensibilização da vontade" (qualquer estímulo que leva ao desejo da masturbação). Os externos são provenientes, na maioria dos casos, de sites com sexo explícito, sob a forma de filmes e séries em plataformas de streaming ou fotos ou vídeos em redes sociais.

O "efeito caçador" ou "fissura" são tipos específicos de imaginação que levam o indivíduo a ficar "perturbado por desejos e fantasias", até consumar nova recaída.

"Desde os últimos dias estava sofrendo com a pressão da fissura, hoje acordei de madrugada $1 \mathrm{~h}$ antes do despertador tocar perturbado pelos desejos e fantasias. Fiquei na cama lutando com meus pensamentos durante um bom tempo. Como essa coisa atrapalha a vida do cara". (Pequeno Cristo, socializador)

"Aí num domingo de manhã, (...) a líbido e a sensibilidade estavam lá no alto. Aí caí feio. Efeito caçador veio com tudo e acabou comigo" (Randy, confidente) 


\section{Objetificação da mulher}

O consumo compulsivo e excessivo de pornografia on-line por homens está frequentemente associado à objetificação da mulher, constatação de alguns estudos (WIEGMAN, 2002) e encontrada em relatos de membros da comunidade. A definição dada pelo dicionário parece se encaixar no que os participantes entendem por objetificação: "Processo que atribui ao ser humano (com vida) a natureza de um objeto material (sem vida)". Eles descrevem que sua maneira de ver as mulheres tornou-se "viciada", a ponto de vê-las apenas como objeto de desejo, "afetando fortemente a vida social”.

\footnotetext{
"meus olhos ficaram viciados, e sempre que saio na rua, sempre coloco os olhos onde uma pessoa saudável não colocaria - mulher virou objeto para mim. Esse é um dos piores efeitos no vício em pornografia, na minha opinião, pois afeta fortemente a vida social." (Vierkess, socializador)
}

Um estudo com 117 mulheres a respeito do consumo de pornografia on-line por parte de seu parceiro, atual ou anterior, mostrou que objetificação impacta diretamente na autoestima e no bem-estar, afetando negativamente o relacionamento (TYLKA; KROON VAN DIEST, 2015). Como estímulos visuais provocam prazer aos consumidores desde a puberdade (BAUMGARTNER et al., 2012; BEYENS; EGGERMONT, 2014), e eles são absorvidos por muito tempo pela pornografia até o momento em que têm o primeiro contato real com uma mulher, o comportamento acaba ficando condicionado a "só ver sexo nelas".

"a gente não se relaciona saudavelmente com as mulheres porque só vemos sexo nelas. Mas, graças à Deus, a gente só estamos condicionados. Com o reboot tudo melhora. A gente aprende a olhar uma mulher por amor e não por sacanagem" (Blpr, confidente) 
O desejo por parceiras sexuais não parece ser um problema em si para os membros com quem interagi. Para eles, o sexo é algo saudável se estiver livre das influências negativas da pornografia, na imaginação e no trato com as mulheres. Lewin (1997) descobriu relação positiva entre o número de parceiros sexuais e a volume de consumo de pornografia, o que explica, em parte, o desejo dos consumidores de substituir o estímulo artificial pelo natural. Replicando esse estudo, Traeen e colegas (2006) encontraram o mesmo padrão entre consumidores noruegueses.

Poucos na comunidade reconheceram que o número de parceiras pode desenvolver compulsão em sexo (OWENS et al., 2012), pois sua visão é de que o nível de bem-estar tende a crescer com o aumento de relações sexuais.

A forma de olhar a mulher como objeto faz com que qualquer contato visual esteja orientado à cópula (satisfação sexual). Esse pensamento excessivamente sexualizado parece impedir que haja conversas saudáveis sobre qualquer assunto, a ponto de gerar "bloqueios mentais".

"Sou covarde mesmo, sou apático. Muitas mulheres me dão abertura, principalmente na academia, mas tenho bloqueios mentais que me impendem de agir. São questões de natureza econômica e objetivação da mulher (meu interesse apenas de cunho sexual e para nada além disso). Não tenho qualquer interesse por mulher se não for para copular, esse sempre é o alvo final, simplesmente não consigo manter um contato pelo simples contato. A intenção velada ou direta, é o coito." (CoyoteStrong, confidente) 
Em outros casos, a objetificação leva o indivíduo a pagar por sexo para "aliviar as fissuras" e substituir o consumo de pornografia on-line.

"Quando saio com uma GP, eu me alivio e fico por umas duas ou três semanas, sem fissura alguma, o que é muito bom, além de ser uma mulher real. É a tal coisa: é melhor uma GP do que PMO. (...)

Essas transas são mecânicas e dão um sentimento de vazio logo depois que passa, porém me deixaram aliviado sem grandes fissuras depois delas. (Randy, confidente)

Ariely e Loewenstein (2010) descobriram que indivíduos que se envolveram em caso extraconjugal tinham probabilidade 3,18 vezes maior de usar pornografia do que indivíduos que não tiveram. O mesmo estudo também revelou que pessoas que se envolveram em sexo pago eram 3,7 mais propensas a usar pornografia do que as que não pagaram por sexo. Não são comuns nos relatos estudados menções a infidelidade matrimonial, já que o recorte etário foi entre 20 e 29 anos, com poucos casados, mas a busca por prostitutas é comum. A opinião majoritária é de que a relação sexual com profissionais do sexo prejudica a recuperação e agrava a objetificação da mulher, além da possibilidade de desenvolver compulsão.

"Os diários que leio aqui, que falam sobre prostituição, incluindo o seu, $99 \%$ do que leio é negativo. Eu acho que se eu fosse numa GP, correria um risco imenso de me viciar nisso - já que seria minha única forma de fazer sexo. (Vierkenes, confidente).

O diário do Headbanger descreve o desenvolvimento de compulsão em sexo pago desde o primeiro contato, em 2016, quando tinha 23 anos, até 2019, quando finalmente percebeu algumas consequências negativas de recorrer a este tipo de sexo. O motivo declarado no primeiro momento era de que "precisava fazer sexo com mulheres" e que isso seria bom para que se recuperasse da dependência em pornografia. Contudo, em um segundo momento, as mesmas consequências, 
associadas a tristeza profunda, aprofundaram-se em depressão, pensamento suicida e distúrbios sexuais causados pela procura constante por prostitutas.

"eu não estou conseguindo ser forte. Os sentimentos de rejeição e impotência perante a vida batem com muita força, os pensamentos suicidas vêm com força total, e pra não ficar sofrendo acabo tendo as recaídas com putas e pornografia" (Headbanger, socializador)

Usar as prostitutas como objeto, para Headbanger e para outros membros da comunidade, se tornaram meios para esquecer os sintomas causados por ele próprios, deixando-os presos a um ciclo (YOUNG, 2008). Esse padrão, também observado em outras formas de consumo compulsivo (HIRSCHMAN, 1992), é evidenciado pelo comentário de Headbanger: "eu me sinto um lixo por ser um total fracassado socialmente", então "procuro prostitutas para me afirmar". A seguir, ele relata que volta a sentir um "vazio" e recorre a garotas de programa novamente.

\begin{abstract}
"Eu percebo que uso o sexo/PMO como uma espécie de válvula de escape. Funciona assim, eu me sinto um lixo por ser um total fracassado socialmente e com as mulheres, então eu procuro prostitutas para me afirmar. (...) Se alguém aqui pensa em entrar nessa vida, eu recomendo que não faça isso. Só vai perder dinheiro e o vazio que você sente não vai passar, pelo contrário, você vai se sentir pior ainda, sujo e desvalorizado." (Headbanger, socializador)
\end{abstract}

O "vazio" que Headbanger descreve como consequência do sexo com garotas de programa também ocorre com o consumo de pornografia e parece estar relacionado com a queda relevante da autoestima e autocontrole, pois sempre é acompanhado de autodescrições negativas: “o vazio que você sente não vai passar, pelo contrário, você vai se sentir pior ainda, sujo e desvalorizado" (Headbanger). Não se trata de somente tristeza, mas de sentimento com relação as próprias capacidades. 


\section{Queda relevante da autoestima}

Relatos sobre redução da autoestima estão presentes em todos os diários com que interagi, manifestada sob diferentes formas e diferentes intensidades. Os demais comportamentos compulsivos e a compra compulsiva também são fortemente associados a autoestima (RUVIO et al., 2014; DARRAT et al., 2016). As consequências da pornografia e da masturbação na autoestima são manifestadas utilizando adjetivos que conotam sujeira ("eu me sinto um lixo", Headbanger), desânimo ("minha vida ta uma bosta!", Arqueiro de Jesus), autodestruição ("fico com a autoestima destruída quando estou praticando PMO”, CoyoteStrong), escravidão (“estou há quase 3 anos preso novamente nesse vicio maldito", Vegeta), dificuldades em relacionamentos ("não conseguia mais me relacionar com mulheres, tinha poucos amigos", Joseph), vergonha ("com muita vergonha, tenho de reportar a recaída que tive", Kuroro), patologia ("sou uma pessoa doente", Vierkess). Todas parecem ser descrições da queda relevante da autoestima. Alguns estudos sobre compulsão em pornografia on-line consideram termos como solidão, vergonha, depressão, isolamento social como associados à baixa autoestima (YOUNG, 2008; IWEN, 2015).

Os temas mais recorrentes nos diários foram insegurança e ansiedade em se relacionar com mulheres e homens (BECHARA et al., 2003), perda da autoconfiança na própria masculinidade (WONG et al., 2014) e problemas interpessoais (SCHNEIDER, 2003). Os relatos indicam que a dificuldade em se relacionar, proveniente da queda da autoestima, não parece estar restrita a relações em que há interesse sexual (objetificação da mulher), mas "para qualquer lugar que tenha contato com pessoas" (Rivera). Parece que o consumo compulsivo em 
pornografia afasta da realidade, tanto na perspectiva sexual como das relações humanas em geral (CAVAGLION, 2009). O sentimento que os impede de interagir pode estar relacionados ao medo ("mesmo se uma mulher se declarasse pra mim, eu ainda teria medo de ser ridículo ao me aproximar dela”, Kuroro), à insegurança e à "falta de energia" (Bart).

A dificuldade de interagir parece ser mais ampla do que ver a mulher como objeto de prazer. O consumo compulsivo de pornografia parece causar insegurança tão incisiva que impede o relacionamento com qualquer pessoa, de qualquer sexo ou idade. A insegurança com mulheres às vezes pode ser consequência do medo de ter uma dificuldade (disfunção, termo utilizado no fórum) erétil, como muitas vezes foi explicitado pelos membros da comunidade. No diário do Vierkess há um comentário que expõe a tentativa de relacionamento com o sexo oposto e a insegurança.

\begin{abstract}
"Internamente, eu entrei em pânico. E logo depois a paralisia. Saí imediatamente de perto dela e fui pro lado de fora. Acho que ela não entendeu nada - isso que dá, se envolver com quem tem sérios problemas. Um tempinho depois ela saiu, foi até mim, perguntou porque eu sai de perto dela do nada. Ela colocou a mão no meu ombro, e eu tremi. Senti agonia. Afastei ela, muito delicadamente. Ela ficou sem entender, mas continuou conversando comigo." (Vierkess, confidente)
\end{abstract}

Preocupados com o desempenho sexual e o relacionamento com mulheres, os consumidores com quem interagi relataram que não se sentem "homens", na plenitude do termo, e colocam como principal objetivo do reboot a esperança de um dia não terem mais flatline (perda da atração sexual), disfunção erétil (impotência sexual) ou qualquer insegurança com as mulheres. Dito de outra forma, se sentirem “mais homens". A preocupação não é, normalmente, com a saúde ou com religião, como muitos artigos apontam (PERRY, 2016; OWENS et al., 2012), 
mas com a recuperação, psicológica (autoestima), e consequentemente física (ereção), de sua masculinidade. Taylor e Jackson (2018) apontam que é comum, entre os dependentes em pornografia on-line, o desejo de "querer o poder de volta a partir da reconexão de sua masculinidade interior, abandonando as fantasias e conectando-se a mulheres reais como principal objetivo. Eles buscam a recuperação para resgatar sua autêntica masculinidade que foi perdida pela pornografia" (TAYLOR; JACKSON, 2018, p. 630). Esse resgate, percebido em diários da comunidade, surge pelo incentivo ao "contato real" com mulheres e a "religação do cérebro" (reboot), referindo-se ao estado de insegurança, à baixa autoestima, à ansiedade e à vergonha de não corresponder a expectativa da parceira.

\begin{abstract}
"Enfim, minha dica é essa, durante o reboot, além de não ver pornografia, não se masturbem, mas podem transar (é muito bom para religar o contato real). Acredito que eu tenha me masturbado 40 vezes durante esses 6 meses, por isso ainda não me curei da DE” ( $\mathrm{Fc} 1992$, confidente)

"Cara, alguns relatam que o sexo pode ser bem benéfico para a religação e esse o principal objetivo do reboot, nos voltar para o mundo real. (Potiguar, confidente)
\end{abstract}

Quando um membro da comunidade relata que terá um próximo encontro sexual com uma mulher, sempre recebe comentários motivacionais e elogios. O namoro e o sexo sem compromisso são o caminho para a recuperação da compulsão, por isso mesmo comemorados e incentivados por todos. O encontro sexual casual simboliza a reconquista da masculinidade, obscurecida pela reprodução artificial do sexo através da masturbação estimulada pela pornografia on-line. Quando relatam insucesso causado pela impotência, os outros membros declaram seu pesar.

"Voltando a ultima garota, ela me disse pra eu n tomar remédio nenhum, me disse para ir no psicologo ver o negocio da ansiedade e da pornografia, mas também me disse que ela seria o homem da relação (...) me senti o pior cara do mundo, é humilhante de mais, foi o pior dia da minha vida, não consigo descrever o tanto de coisas que passou na minha cabeça, mas resolvi de uma vez por todas procurar ajuda, não quero passar por isso nunca mais" (Fc1992, confidente) 
No estudo de Jackson e Taylor (2018) em uma comunidade norte-americana de indivíduos que se autodeclaram dependentes em pornografia on-line, os membros explicaram que "o objetivo principal da recuperação é o sexo com mulheres reais, porque a pornografia roubou sua masculinidade inata" (JACKSON; TAYLOR, 2018, p. 629). Na comunidade aqui estudada, o objetivo dos membros parece ser o mesmo, mas não identifiquei a expressão "retorno da masculinidade", mas sim "autoestima em relação as mulheres". Minha experiência na comunidade norte-americana NoFap, a mesma que foi objeto do estudo de Jackson e Taylor (2018), durante meu processo de recuperação, colaborou para inferir a associação dos termos.

\section{Problemas pessoais e profissionais}

Embora o consumo de pornografia seja por indivíduos de forma solitária e privada, o impacto que gera no sistema familiar, no trabalho, na saúde e na vida do consumidor pode ser considerável - ainda que não seja totalmente conhecida (BAUSERMAN, 2006). São essas algumas das primeiras dimensões sentidas por quem excessivamente consome pornografia (PERRY, 2016; DORAN; PRICE, 2014).

Nas esferas pessoal e profissional, foram identificadas quatro consequências do consumo compulsivo de pornografia on-line, a partir dos relatos nos diários: vida dupla, escondendo o consumo da sua parceira e buscando a pornografia como anestésico; redução do interesse sexual; dificuldade de organizar a vida; procrastinação de tarefas escolares e profissionais. 
$\mathrm{O}$ constrangimento em consumir pornografia on-line, bem como as consequências relacionadas à compulsão, podem levar o indivíduo a esconder o consumo de outras pessoas, principalmente do cônjuge (PERRY, 2017). Alguns membros relatam que revelaram à parceira ou a amigos próximos, mas não conseguem tornar pública sua compulsão, porque o "meu vicio secreto tem me feito muito mal." (Joseph).

\begin{abstract}
"Ontem conversei com o pessoal do trabalho sobre o vício em pornografia, uma colega minha conhecia os outros não e ficaram surpresos sobre isso, não revelei que estou passando pelo reboot, mas foi a primeira vez que conversei sobre o assunto pessoalmente e isso foi bom pra mim" (Potiguar, confidente)
\end{abstract}

Hertlein e Piercy (2012) argumenta que, em certos casos, o consumo de pornografia pode ser considerado como uma "infidelidade virtual", inibindo o consumidor de revelar a fraqueza ao cônjuge. Não foi comum encontrar esse problema nas faixas etárias com que interagi (20 a 29 anos), mas, na seção “30 anos ou mais" e nas entrevistas (como adiante será relatado), esse tema é recorrente em diários de pessoas casadas ou que tiveram relacionamento estável por tempo considerável. Na comunidade, há uma seção chamada "Namoradas de Rebooters e/ou Viciados" e, em um dos posts, duas mulheres, cujos cônjuges consomem compulsivamente pornografia, expressam a situação:

"Me sinto extremamente mal com isto, já tentei ajudar e até ofereci terapia. Não deu em nada. Passo muito mal com a ideia de que ele está lá se masturbando enquanto observa o corpo de outras mulheres e as deseja" (Cstlvn, principiante, no post "Sério, preciso de conselhos")

"Nossa, eu sei como isso dói... Meu marido tbm mentiu muito pra mim e tive que dar vários 'xiliques' até ele admitir o problema, resolver que quer mudar, aceitar ajuda. $O$ problema realmente tá quando o cara não admite e não aceita ajuda." (Natasha32, principiante, no post "Sério, preciso de conselhos") 
A perda do interesse sexual, consequência manifestada pelos consumidores, é constantemente associada à impotência ou à substituição do sexo real pelo virtual. Nos depoimentos, percebe-se que a perda do interesse pode ser parcial (somente sexo, "objetificando" a parceira) ou total (na pessoa da parceira), provocando insatisfação conjugal (PERRY, 2016), tensões no sistema familiar (REID et al., 2010; SCHNEIDER, 2003) e culminando em divórcio (SCHNEIDER, 2000).

"Como eu adquiri DE devido a PMO, ainda não me sinto totalmente confiante para manter relações sexuais com ela... e isso me deixa bem preocupado" (Wildwarrior, confidente)

"Cara, alguns relatam que o sexo pode ser bem benéfico para a religação e esse o principal objetivo do reboot, nos voltar para o mundo real. Acho que você deve sentir o momento, se não rolar não insista, se sua parceira for compreensiva ela vai entender." (Potiguar, confidente, Diário do WildWarrior)

Perda de sono, sonolência durante o dia, diminuição da capacidade de memorização e outras consequências negativas estão associadas ao consumo excessivo de Internet e de pornografia (LAIER et al., 2013). Nos diários que li, observei que alguns consumidores compulsivos declaram ter dificuldade de gerenciar a própria vida, sobretudo porque estão desordenados, cansados e com alta instabilidade emocional. Alguns relatam que não conseguem terminar o que se propõem a fazer e que tais consequências impactam significativamente em seu desempenho acadêmico (WITTWER; SENKBEIL, 2008), profissional (HERTLEIN; PIERCY, 2008; WRIGHT; RANDALL, 2012) e nas tarefas do diaa-dia (KAFKA, 2000; BLACK et al., 1997).

A queda no desempenho escolar é associada ao tempo gasto assistindo pornografia: em média, consomem de três a seis vezes ao dia: "todos os dias eu sentia necessidade de consumir pornografia e tudo isso acabou me prejudicando na escola, levando até uma reprovação" (Vegeta). Em um estudo recente consumidores compulsivos de pornografia relataram dedicar até quinze horas a pornografia por 
semana e isso afeta a vida profissional (LAIER; BRAND, 2016), pois gera "procrastinação de tarefas", "baixa autoestima" ou "falta de energia".

"Sei que a procrastinação, baixa motivação e criatividade são originadas da PMO, pois sempre que faço abstinência eu tenho meu ápice no trabalho, chegando ao ponto de muitos dizer que eu tinha mudado. (...) A PMO é a maior ladra de energia da natureza, energia essa que você para trabalhar, estudar..." (New Man11, confidente)

\section{Distúrbios sexuais}

Os distúrbios podem ter origem psicológica e/ou orgânica (HEIDELBAUGH, 2015). O primeiro tipo está associado à depressão, ao estresse e à ansiedade enquanto o segundo a hormônios, a fármacos e a aspectos anatômicos (HEIDELBAUGH, 2015). Pelo que se percebe na comunidade, os indivíduos atribuem aos distúrbios sexuais procedência psicológica: "Por conta disso tudo, desenvolvi muitos transtornos psicológicos, como o próprio HOCD” (Trent), provocados pelo consumo excessivo de pornografia on-line. Organizei os temas recorrentes relacionados a "distúrbio sexual” em quatro grupos: dessensibilização e sensibilização (KUHN; GALLINAT, 2014); dificuldade em manter ereção (MIALON et al., 2012; O’SULLIVAN et al., 2014; VOON et al., 2014); desejos estranhos (SEIGFRIED-SPELLAR; ROGERS, 2013); e crise de identidade (TAYLOR; JACKSON, 2018).

A disfunção erétil (DE), ou dificuldade em manter ereção, reconhecida como consequência do consumo excessivo, é comum em muitos relatos dos membros da comunidade, mas não em todos os estudados. Alguns consumidores passam mais de uma década consumindo pornografia regularmente e não relataram ter problemas de ereção. É senso comum nos diários que o reboot pode curar a disfunção, uma vez que o “cérebro precisa se religar” (Fc1992). 
"Com 18 anos, finalmente perdi a virgindade. Tive DE. Como eu não podia me excitar com uma mulher real? Isso foi acontecendo nas outras poucas relações sexuais que tive." (Randy, confidente)

Antes do surgimento da Internet, os casos de DE eram significativamente menores (PARK et al, 2016), encontrado em 5\% dos casos DE homens de 18 a 59 anos (LAUMANN et al, 1999). Outro estudo (PRINS et al., 2002) apontou 2\% para indivíduos com menos de 40 anos. Em contraste, estudos recentes sobre DE têm mostrado relevante crescimento (PARK et al., 2016). Em um grupo de jovens europeus de 20 a 40 anos, com vida sexual ativa, a disfunção erétil foi relatada em 14 a 28\% dos casos (LANDRIPET; STULHOFER, 2015). Mialon e colegas (2012) a encontraram em $30 \%$ dos jovens suíços, com idade entre 18 e 24 anos. Finalmente, Klein e colegas (2015) mostraram significativa correlação do consumo de pornografia com problemas de ereção.

Pelos diários, percebe-se que os consumidores relatam estarem mais sensíveis e predispostos a retomarem ciclo PMO mediante algum estímulo externo que excite a imaginação (ROBINSON; BERRIDGE, 1993; VEZINA; LEYTON, 2009; PARK et al., 2016). Ao mesmo tempo, relatam não terem "vontade de transar com nenhuma mulher" (CoyoteStrong), pois a insegurança proveniente da “dessensibilização", descrita na literatura como a redução da capacidade de se obter prazer em situações naturais que deveriam gerar excitação (KUHN; GALLINAT, 2014), os leva a evitar relações sexuais. CoyoteStrong relata esse paradoxo em uma única mensagem. Os colchetes foram meus.

"Hoje não tenho vontade de transar com nenhuma mulher, pois sei que vou falhar [dessensibilização] e além disso sei que tenho uma fonte inesgotável de prazer no mundo virtual [sensibilização]" (CoyoteStrong, confidente) 
A dessensibilização como consequência do uso constante de pornografia é comparável ao aumento da tolerância existente em outras formas de compulsão, pois “a exposição intensa a estímulos pornográficos resulta em uma infra-regulação (dessensibilização) da resposta neural natural a estímulos sexuais" (KÜHN; GALLINAT, 2014, p. 832). Koukounas e Over (2000) exibiram para um grupo repetidas vezes o mesmo filme pornográfico e constataram que o prazer percebido diminuía a cada nova exibição do conteúdo. Após dezoito visualizações do mesmo material, apresentaram um vídeo diferente e constataram que a excitação dos indivíduos voltou a aumentar.

Como os consumidores não conseguem mais obter a mesma quantidade de prazer em situações reais, ou em vídeos de sexo explícito envolvendo homem e mulher, porque embora cenas diferentes envolvam uma mesma dinâmica, relatam que sentem necessidade de buscar estilos mais "pesados" e, às vezes, "contrários à própria vontade", mas que geram semelhante quantidade de prazer. Em uma comunidade nos Estados Unidos, semelhante a Como Parar, mais da metade dos entrevistados concordou com a afirmação "minhas preferências tornaram-se cada vez mais ‘extremas' ou ‘depravadas”” (TAYLOR; JACKSON, 2018).

Hirschman (1992) indicou que dependentes passam a consumir quantidade maior do que a habitual, ou recorrem a outros estímulos (o consumidor de álcool começa a consumir cocaína). Os membros da comunidade relatam terem dificuldade de reconhecer a si próprios quando a compulsão leva a "desejos extremamente pesados" (Joseph), porque sentem necessidade de conteúdo que contraria sua própria vontade (JANSSEN; BANCROFT, 2007; ZILMANN; 
BRYANT, 2006): "sinto desejos estranhos que não condiz com meus princípios" (Joseph).

"a pornografia naquele momento foi mais interessante, meu pênis perdeu a sensibilidade, vocês me entendem? só sinto prazer em gostos extremamente pesados, eu espero que isso mude, eu luto por isso."(Joseph, confidente)

A dessensibilização como antecedente do consumo de estilos "mais pesados" foi apontada por outros estudiosos (JANSSEN; BANCROFT, 2007; ZILLMANN, 1986) e é similar ao encontrado em consumo de outras drogas (HIRSCHMAN, 1992). O HOCD (Homosexual Obsessive Compulsive Disorder), por exemplo, é um transtorno obsessivo-compulsivo que faz o indivíduo de orientação heterossexual acreditar que pode ser homossexual porque o consumo excessivo de pornografia o levou a assistir conteúdo envolvendo relação entre homens ou com travestis. Segundo o manual fornecido pela comunidade, o HOCD "está baseado no medo que uma pessoa heterossexual sente em se tornar ou ser homossexual. Este medo é impulsivo e sem controle, onde a pessoa se sente muito ansiosa e temerosa em relação aos seus pensamentos obsessivos sobre ser homossexual ou se apaixonar por pessoas do mesmo sexo" (COMO PARAR, p. 11). Eles atribuem essa necessidade, contrária à própria vontade, ao longo tempo consumindo pornografia on-line. Os membros da comunidade adotam a sigla HOCD quando relatam essa inclinação.

"Mas graças a Deus eu meio que aprendi a lidar com meu HOCD depois de tanto tempo com ele, eu não me saboto tanto mais, sei que isso é coisa da minha cabeça, não é quem eu sou de verdade, mas MESMO assim não da pra controlar isso 100." (Trent, socializador, Diário de Trent) 
Diferente de Trent, onde HOCD era uma das consequências percebidas, para Henrique1gomez o HOCD é o centro da sua compulsão, a ponto de seu diário chamar- se "luta contra o HOCD". Ele descreve a profunda crise de identidade em que se sentiu afundar por conta do tipo de materiais que, contrariando sua vontade, sentiu-se compelido a consumir:

"Saí do pornô hétero e hentais para o shemale. Mergulhado nessas coisas, passei a ter uma crise de identidade (...) Nisso acabei tendo uma relação homossexual com meu próprio irmão, e eu só mergulhado em mais pornô shemale." (Henrique1gomez, confidente, Luta contra o HOCD)

Quando o tipo de consumo viola valores sexuais ou morais (GRUBBS et al., 2018; ROOK et al., 2014), o usuário atribui essa necessidade a uma crise de identidade, um tipo de dissonância cognitiva, que é uma contradição entre duas crenças (FESTINGER, 1957). No caso de relatos estudados, a dissonância parece ocorrer quando percebem que não gostam de material homossexual, ou de outro tipo, mas, mesmo assim, sentem compulsão de consumi-lo, independentemente de obter ou não a prazer. Quanto mais o material distorce os estímulos naturais (sexo entre homem e mulher), maior parece ser sua contradição interna.

"na hora que eu abri o vídeo eu não consegui evitar. Um vídeo ainda nojento de zoofilia, não sei como acabei parando nisso, é inexplicável o quanto esse vício nos deixa cego..."(Mshsos, devoto, Qual o preço da minha liberdade)

Quanto menor a idade do primeiro contato com a pornografia on-line, maior parece ser a probabilidade de consumir materiais relacionados a zoofilia ou pornografia infantil (SEIGFRIED-SPELLAR; ROGERS, 2013). Alguns fetiches, segundo os participantes, transbordam o limite do virtual, afetando a vida do indivíduo e de terceiros, como o "froteurismo", ou desejo de encostar as genitálias em uma pessoa desconhecida. Em todas as vezes em que foi manifestado, os diários 
a tratam como algo do passado ou que conseguiram evitar. Os relatantes veem esse ato como errado, mas o atribuem à falta de controle sobre seus impulsos. O diálogo do Arqueiro com mais duas pessoas mostra que outros também tiveram as mesmas reações.

“(...) no metro lotado a mente suja ficou martelando para eu da uma de tarado como eu fazia antigamente tarar a minas no metro. Graças a deus conseguir me controlar..." (Arqueiro, confidente)

"Te entendo, Arqueiro hehehe. Com meus 12 anos passei um período indo em supermercados e lugares cheios só pra encoxar ou passar a mão na bunda/perna de mulheres. Chega a ser doentio pensar nisso hoje" (W. Burk, confidente, Diário do Arqueiro de Jesus)

“Às vezes, neste relato, lembro que era eu. Este vício deixa a gente assim. Com a cabeça só pensando sacanagem e dessa forma a gente não se relaciona saudavelmente com as mulheres porque só vemos sexo nelas" (Blpr, confidente, Diário do Arqueiro de Jesus)

Nesse estágio, segundo os relatos, o sentimento após o comportamento é de nojo, de repulsa e profunda tristeza. Tendem então a buscar ajuda para parar, sentindo que foram longe demais.

Desenvolvidos os distúrbios sexuais, alguns participantes da comunidade apresentam aparente desesperança, se sentem deprimidos e pensam constantemente em suicídio (alguns chegando a tentar de fato), por considerarem que o único alívio para a dor da compulsão seria dar fim à vida.

\section{Depressão e pensamento suicida}

Depressão e pensamentos suicidas parecem estar no limite do consumo de pornografia (YOUNG, 2008; CAVAGLION, 2009; TAYLOR; JACKSON, 2018). Alguns diários relatam depressão, ansiedade e problemas familiares e que a busca da pornografia alivia essas consequências (LEVIN et al., 2012; KAFKA, 2000; BLACK et al., 1997). Não foi encontrado qualquer caso de indivíduos que 
chegaram a este estágio sem ter passado por muitos anos de consumo excessivo de pornografia. Um longo período de consumo gera dessensibilização que induz a buscar "pornografia pesada" ou em maior quantidade para obter o mesmo nível de prazer (JANSSEN; BANCROFT, 2007).

"Olá galera, 22 anos sou viciado desde de que tinha uns 12 anos só saquei que era viciado no começo de 2015 , quando tive depressão e então me tratei com psiquiatras, psicólogos tomava remédios controlados. Tentei suicídio, mas meu irmão me salvou no dia! NÃO SABIA A CAUSA da Depressão: "PORNOGRAFIA". Hoje eu sei, perdi empregos! Minha vida ta uma bosta!!! Eu me masturbava quase todo dia 3;5 vezes por dia já me a pornografia quase me matou varias vezes tava tão pirado da cabeça que cheguei a pagar para sair com garotas de programas, as piores que vocês possam imaginar 15 reais, 10 reais, 5 reais 7 reais uma vez!!! Eu tive relações com travestis, com gay, mas eu sou heterossexual !!! (Arqueiro, confidente, Diário do Arqueiro de Jesus).

O comportamento é esperado em casos em que há desenvolvimento profundo da compulsão: "pensamentos suicidas ocorrem em algum momento, para cerca de metade dos indivíduos” (APA, 2014, p. 240). Quando o indivíduo descobre que não consegue mais se livrar de um determinado comportamento compulsivo, pode desenvolver depressão (MATUSIK; MICKEL, 2011). Parecem ser mais evidentes casos de depressão e de pensamentos suicidas quando o consumo excessivo de pornografia on-line está associado a outras compulsões, como ocorreu com Vierkess, usuário compulsivo de bebida alcoólica.

\footnotetext{
"Durante novembro e a maior parte de dezembro, mergulhei em uma depressão pesada. Bebia muito todos os dias, não tinha perspectiva de nada e não conseguia agir para mudar a situação. Vida social zero, o dia inteiro no computador e consumindo pornografia diariamente. Pensava com muita frequência em suicídio" (Vierkess, confidente, Diário do Vierkess)
} 


\subsection{Entrevistas}

\subsubsection{Três histórias de vida}

Três histórias de vida de entrevistados que se autodeclaram consumidores compulsivos de pornografia on-line, que diferem significativamente entre si, mas representam o que foi relatado pelo conjunto de entrevistados, servem para ampliar achados que emergiram da Netnografia.

História de Broda: Broda tem 23 anos, é solteiro e vive com os pais. Formou-se em administração e atualmente trabalha como gerente de tecnologia. Escolhi a entrevista com Broda por quatro motivos: 1) trata-se de um dos mais experientes usuários da comunidade; 2) a antecedência do consumo passa pela desestrutura familiar durante a infância; 3) as consequências chegaram "ao ponto mais baixo" e 4) discorda da maioria dos usuários da comunidade quanto aos benefícios de parar o consumo de pornografia.

Ele teve o primeiro contato com pornografia aos nove anos de idade enquanto seu pai navegava na internet, mas somente aos 12 anos passou a consumir diariamente. Sua mãe tem depressão e a relação entre os pais sempre foi difícil. Ele relatou que começou por materiais "mais leves, como mulher sem sutiã", que naquela época era "super excitante", mas que depois passou a não mais excitá-lo. Procurou então cenas de "sexo explícito, depois suruba e foi piorando até chegar a ler contos eróticos de incesto e zoofilia”. Ele descreve que a pior consequência do consumo de pornografia na adolescência ocorreu aos 14 anos, quando estava na casa de sua tia. Neste dia, olhou para uma cadela que havia na casa e teve vontade de fazer sexo com o animal. Broda descreve esse episódio com palavras de lamentação e nojo e conclui que "depois desse dia nunca mais leu contos eróticos 
pesados". Entretanto, ainda não percebia que a pornografia em si lhe fazia mal. Com 17 anos, descobriu a comunidade Como Parar e percebeu que é dependente de pornografia on-line. Diferentemente de quando começou a consumir, quando "era bom e prazeroso", agora, que tem consciência da compulsão, todo novo ciclo PMO que realiza o faz sentir-se mal, "uma espécie de desgosto" após o consumo. As consequências também se tornaram mais claras, associando a queda do desempenho nos estudos ao "tempo gasto com pornografia", pois "deixava de estudar para ficar consumindo e isso acontecia várias vezes. Isso afetou meu senso de responsabilidade com as tarefas".

Desde que começou a participar da comunidade, há cinco anos, Broda se absteve do consumo por longos períodos e critica os demais participantes que atribuem à cura da compulsão uma série de fatores positivos na vida: “Quando você entra no fórum e lê os relatos de sucesso, parece que às vezes você vai parar de consumir e você vai se tornar um sujeito incrível. Você vai conseguir tudo que você quer". Segundo ele, os únicos benefícios percebidos foram o "aumento da disposição e mais tempo livre porque, se você parou de consumir, obviamente você vai ter mais tempo. E disposição, porque você não está gastando mais tanta energia”. Broda entende que as consequências (que foram encontradas na netnografia) não desaparecem com o reboot, mas servem como um "catalisador", um unificador ou ponto de partida para uma série de mudança de hábitos. 
História de Edy: Edy tem 33 anos, é casado, cursa faculdade de administração e trabalha como técnico em tecnologia da informação. O primeiro contato que Edy teve com pornografia foi aos nove anos de idade e de forma acidental - ele e seus irmãos acharam revistas Playboy de seu pai. Casos assim foram comuns, tanto nas entrevistas quanto nos relatos nos diários.

Edy é mais velho que os outros membros de cujos diários participei. Nesse sentido, duas situações parecem ser próprias de pessoas com mais de trinta anos: o contato com pornografia on-line ocorreu significativamente mais tarde, pois em sua pré-adolescência não existia internet e, por ser casado, teve dificuldade em revelar para sua parceira a compulsão. Edy também teve longa experiência de consumo excessivo de algumas substâncias químicas, o que evidencia o achado de "dependência em série" do estudo de Hirschman (1992), e consumo contrário as suas próprias convicções sexuais (homossexual, transexual, zoofilia etc).

No trabalho, Edy relata que, em todas as empresas por onde passou, assistia pornografia e se masturbava na hora de seu expediente "mesmo com o risco de alguém pegar e ser mandado embora". Na escola, lembra que teve "dificuldade de concentração, dificuldade de entender as coisas" e que no trabalho esses mesmos problemas continuam aparecendo. Ambos, ao seu ver, estão associados ao consumo compulsivo de pornografia on-line. As namoradas interpretavam a pornografia como uma forma de infidelidade. Edy conta que uma delas "ficava brava" dizendo que está "sendo trocada por revistas e tudo mais". No casamento, sua esposa "entende melhor os problemas" pelos quais passa em resistir ao consumo.

Depois do primeiro contato com a pornografia on-line, aos 21 anos de idade, consideravelmente tarde em relação a depoimentos de outros diários do grupo de 
20 a 29 anos de idade, onde os consumidores relatavam que começaram entre 10 e 14 anos, Edy recorda que teve súbito aumento da tolerância ao material pornográfico, com comportamentos que contrastavam com sua vontade: “os vídeos que eu já tinha visto não me atraiam mais. Eu sempre buscava alguma coisa diferente. Comecei a assistir vídeo homossexual, mesmo não sendo minha orientação sexual. Eu via transexual, zoofilia... mais hardcore mesmo, mais pesado. Tudo que tinha de mais pesado eu ia vendo", o que provocou feridas em sua genitália, e "mesmo machucado e sangrando eu continuava. Eu sabia que estava doendo e não parava."

Durante toda a adolescência, Edy consumiu maconha, cocaína e "mesclado" (mistura de cocaína com crack). Ao falar dessas dependências, Edy se considera um "adicto" e participa de um grupo de narcóticos anônimos desde antes de reconhecer sua compulsão em pornografia: "A gente tem um entendimento lá sobre a doença da adição de que ela migra. Depois que você para com uma droga, ela vai migrar pra outra coisa que te dê prazer. Eu consigo ver a compulsão igualzinho como era com a droga e como é com a pornografia". As consequências do consumo de pornografia on-line na vida pessoal de Edy são muito semelhantes a substâncias químicas, pois "mesmo sabendo que eu estava me destruindo, acabando com a minha família e que eu não era uma boa pessoa usando, eu não conseguia ficar longe. E a pornografia era igual”.

O acúmulo de compulsões e reiteradas tentativas de abster-se das drogas e do comportamento, levou-o a perder a vontade de viver. "Eu realmente não vivia. Eu sobrevivia. Vegetava. Eu usava o dia todo, a noite toda" e isso gerou, em sua avaliação, a "depressão e o pensamento suicida", pois "não conseguia parar". Edy 
relata que suas compulsões em série são manifestações de um desejo autodestrutivo que tem desde a adolescência.

História de Peter Parker: Peter Parker tem 20 anos, é solteiro, cursa engenharia e vive com seus pais. Diferente de relatos de todas as entrevistas realizadas, Peter Parker sabia desde o primeiro contato, aos 11 anos de idade, que o consumo de pornografia não era bom. Contudo, a justificativa não era a percepção de riscos que os indivíduos reconhecem depois de uma década de consumo, mas porque, para ele, consumir pornografia ia contra sua fé cristã: "Eu acredito que se eu não fosse cristão, a pornografia não teria problema algum pra mim. Acho que só iria me tocar quando percebesse as consequências, e tal... sexualizar as mulheres e ansiedade, essas coisas”. Embora não tenham sido encontrados neste estudo, casos como o dele, há autores que identificaram probabilidade menor de que indivíduos com forte religiosidade consumam pornografia (PERRY, 2017).

Peter disse que começou a consumir pela Internet após amigos da escola comentarem que estavam acessando sites pornográficos. A pornografia não era para ele uma "válvula de escape" de problemas existenciais, como ocorre para outros do grupo, mas uma forma de prazer e de autoconhecimento, ainda que "sempre achava que era errado fazer". A sua primeira ejaculação ele descreve como "fantástico" e “ incrível”, pois "parecia que tinha descoberto algo novo".

O impacto na vida pessoal foi na queda da autoestima, pois "não conseguia sair na rua", achando que as mulheres iam olhar para ele e pensar "que era um merda, um idiota". Ele descreve que a pornografia foi fundamental para o desenvolvimento de "um quadro de depressão e ansiedade social". Pouco antes de começar o reboot, tinha pensamentos suicidas e chegou a tentar dar fim à vida. 
$\mathrm{Na}$ escola, assim como relatado por Edy, Peter contou "fantasiar suas amigas de sala, professora e tudo mais". Suas notas foram afetadas porque "tentava estudar e não conseguia", uma vez que o seu "imaginário estava lotado de fantasia".

Quando o aumento da tolerância começou a levá-lo a consumir conteúdos pornográficos distintos do sexo entre heterossexuais, por receio de ter HOCD, Peter buscou conteúdo entre lésbicas: "Eu fiquei com medo de um dia acabar desenvolvendo uma homossexualidade e então fiquei muito nesses vídeos com mulheres".

Peter também dedicava muito tempo aos jogos on-line, que considerava ser outra compulsão que precisava superar: "Eu jogava bastante jogo on-line. Bastante mesmo. Eu lembro que era todo dia, passando, duas, três horas. O dia todo se fosse preciso. Eu sempre fui um viciado em jogos mesmo".

Diferente de Broda, Peter reconhece, no breve reboot de 60 dias, ter havido considerável redução das consequências autodeclaradas. "Eu tinha mais tempo disponível, mais energia, mais foco, melhora na socialização, melhora no tratamento com as mulheres, benefícios espirituais e muito mais".

\subsubsection{Categorias comuns a teoria geral de consumo compulsivo}

A compulsão em série e mudança relevante de vida - Os consumidores compulsivos de pornografia entrevistados parecem considerar as várias compulsões de diferentes formas e com realidades distintas. Para eles, o consumo excessivo de maconha, jogos on-line ou bebida alcoólica não parece produzir impacto significativo sobre a saúde, pois o que realmente os prejudica é o PMO. Não foi comum relatarem abstenção de jogos e de pornografia, ou de maconha e de 
pornografia, ainda que os consumam todos os dias e na mesma medida que a pornografia. Isso parece ocorrer pelo mesmo motivo apontado por Hirschman (1992) a respeito da consciência sobre a adição.

Ao pedir que o entrevistado Healthy (22 anos, solteiro) explicasse melhor a época em que fumava cigarro e maconha todos os dias, respondeu:

"Agora que você falou, é verdade. Eu não tinha prestado atenção nisso. Se eu
ficasse um período sem maconha, eu sentia que meu ciclo não estava completo.
Eu tinha que ter os três presentes e nessa ordem: maconha, fumava um cigarro e
depois me masturbava. Para minha noite estar completa, era só isso que precisava".

Healthy não considerava, até o momento da entrevista, a maconha e o cigarro como outras formas de consumo compulsivo e consumia sem qualquer preocupação, algo normal, diferente do que ocorria em relação à pornografia. Healthy, até começar o seu reboot, fumava e se masturbava de cinco a seis vezes ao dia, mas não se considerava consumidor compulsivo de tabaco, somente da pornografia. Em poucos casos, como o de Vierkess, surgiu a consciência da compulsão em mais de um estímulo e dos efeitos na saúde:

"além do vício em pornografia, eu também enfrento outro cruel inimigo: o álcool (problema que eu nunca tratei com a devida seriedade)".

Pedrohfas (26 anos, namorando) reconhece que sua rotina era composta por jogos e pornografia on-line: "eu passava em torno de 10 a 12 horas jogando e depois 2 horas de pornografia. Eu ia para pornografia para descansar antes de dormir".

Hirschman mostrou que as compulsões eram consideradas como partes do mesmo problema, diferente do que ocorre com a maioria dos consumidores de pornografia aqui estudados. Para os consumidores de pornografia on-line, uma mudança relevante de vida pareceu ser antecedente do consumo de pornografia on- 
line, por contribuir no desenvolvimento da compulsão, apesar de eu não ter encontrado, nas interações em diários da comunidade, casos de membros que buscassem pornografia on-line porque estavam aflitos ou inseguros, mas sim como um fator que pode aumentar significativamente o consumo. Períodos de considerável incerteza e de ansiedade, como o ano de preparação para o vestibular, a mudança de cidade ou problemas familiares, servem de gatilhos para que busquem a pornografia como um alívio.

O "Manual diagnóstico e estatístico de transtornos mentais" (DSM-V) indica que substâncias químicas ou comportamentos compulsivos geram “pensamentos, impulsos ou imagens recorrentes e persistentes que são experimentados como intrusivos e indesejados" (APA, 2014). Sem conseguir administrar tais sentimentos, o indivíduo retorna ao consumo (O'GUINN; FABER, 1989). Na comunidade Como Parar, todos os consumidores compulsivos de pornografia assumem que ela causa compulsão e as recaídas são consequências naturais que devem resistir.

Skinner (2003), por exemplo, considera que não existe livre-arbítrio, mas autorregulação emocional, que é a administração de reforços negativos a fim de evitar um comportamento indesejado. Quando passavam por algum gatilho que os colocassem em situação de recaída, alguns participantes da comunidade sugerem banho com água gelada para "passar a vontade", outros sugerem pequenos golpes contra o próprio corpo. A autorregulação com reforço negativo pode fazer com que a probabilidade da recaída seja menor ao longo do tempo (GROSS, 2014).

As recaídas apresentam um padrão que leva o consumidor a um ciclo sem fim. Muitos dizem que consomem pornografia para reduzir a ansiedade, a tristeza 
e outros sentimentos ruins, mas que, mesmo depois do orgasmo, sentem tristeza e recorrem novamente à pornografia. Rodion Romanovich (35 anos, casado) relatou que "quanto mais eu me masturbava, mais eu me sentia mal e quanto mais eu me sentia mal, mais eu fazia". Para Rodion, a compulsão não tem cura e sempre estará com ele. "Por que eu falo que sou viciado? Eu sei que nunca vou me livrar. Eu fico seis meses sem, mas depois eu volto. Se eu não consigo me controlar, eu sei que é um vício. É uma doença". Costa86 (23 anos, namorando) relata que, "após consumir, bate aquele desânimo, aquela tristeza de ter praticado. Antes eu encarava [a pornografia] como alívio da dor, agora bate melancolia...”.

O consumidor compulsivo esconde a compulsão no primeiro momento. Em seguida, quando suas consequências se tornam visíveis, os parentes percebem e se decepcionam. O resultado natural é o distanciamento imediato do consumidor, para evitar mais constrangimento. No consumo compulsivo de pornografia, a decepção é em relação ao cônjuge: quando revela a compulsão à esposa ou à namorada parece simbolizar, em alguns casos, infidelidade, ameaça ao relacionamento ou diminuição do envolvimento emocional. Paulo RMM (23 anos, namorando) relatou que sua namorada ficava "magoada e se sentia traída" ao saber que ele consumia pornografia de forma compulsiva. Paulo concordou com a visão dela porque “chegou ao ponto de alguns momentos íntimos eu não conseguia fazer nada se não tivesse lembrança de algo que eu tivesse visto". Como em todos os outros casos, não prejudicou outras pessoas, apenas a relação com a parceria. Edy (33 anos, casado) relata situação semelhante. Sua primeira namorada, ao descobrir, "tentou jogar fora as revistas" e "ficava muito brava por eu consumir". Com a segunda namorada, Edy conta que as consequências do consumo alcançaram outro nível: "Eu comecei a querer desenvolver as fantasias que eu via no filme com ela e o sexo 
começou a ficar sem graça. Se ela não fizesse as coisas que eu estava acostumado a ver, não tinha graça.”. Após o casamento, Edy recorda que chegou a ter disfunção erétil e que, para ele, "foi a gota d'água".

Rodion Romanovich (35 anos, casado) relata que "não tem qualquer controle sobre seu vício" e que, "além do sentimento de nojo e imundice" após consumir pornografia, ele sente que "trai a confiança da esposa e dos filhos" por ser um homem adulto que não consegue se abster do consumo de pornografia. Sua esposa sabe do consumo desde quando começaram a namorar, há doze anos, mas que, "depois de um tempo", parou de contar os "detalhes porque isso a machucava muito" e, em alguns casos, teve que se desculpar por não sentir vontade de se relacionar sexualmente com ela.

Como a pornografia não deixa sinais visíveis no indivíduo, nem provoca, na maioria dos casos, prejuízo financeiro, a decepção parece estar limitada a quem tem relação íntima com o consumidor compulsivo. Ademais, alguns estudos revelam que o consumo compulsivo pode levar o homem, ou a mulher, a cometer adultério ou querer o divórcio (SCHNEIDER, 2000; BECHARA et al., 2003; BAUSERMAN, 2006).

Essas consequências foram consideradas como viver vida dupla, pois o consumo compulsivo faz com que a vida, segundo os relatantes, seja dividida entre consumir pornografia e sentir falta do consumo; e resulta em redução do interesse na parceira, provocado pela substituição do estímulo sexual físico pelo imaginário (i.e. filmes pornô).

Hirschman, identificou três tipos de famílias desestruturadas que colaboraram para formação de um indivíduo dependente: as famílias onde pais 
consumiam drogas na presença dos filhos; onde houve abuso físico ou emocional; e as que condicionavam o amor dado aos filhos às suas expectativas e demandas.

No caso da pornografia on-line, alguns entrevistados que cresceram em famílias desestruturadas parecem ter maior probabilidade de desenvolver algum tipo de desequilíbrio emocional, que poderá servir como gatilho para o consumo. Foi o caso de Costa86 (23, namorando), cujos pais divorciaram no início de sua infância e teve que conviver com padrasto consumidor compulsivo de álcool e de maconha. A falta de estabilidade familiar pode ter contribuído para o consumo compulsivo de pornografia, mas não parece ser antecedente que cause compulsão, uma vez que o primeiro contato e o desenvolvimento do consumo foram semelhantes aos demais membros estudados.

O que parece ser determinante são a acessibilidade, a gratuidade e a disponibilidade de conteúdo pornográfico na Internet durante a infância (OWENS et al., 2012). Pedrohfas (26, namorando) relatou que a falta de estrutura de sua família fez com que desenvolvesse desequilíbrio emocional, onde a pornografia e jogos passaram a ser "refúgios", alívio temporário dos sentimentos causados pela infância desregulada. A justificativa de parar de consumir pornografia, para Pedrohfas, foi a partir do seu primeiro namoro: "Eu sempre quis ter uma família e eu acho que a pornografia é um refúgio. Como eu tenho essa pessoa, eu não preciso fugir para a pornografia”. Em casos menos frequentes na comunidade, há histórico de abuso sexual durante a infância, como relatado por iJames:

"Fui abusado sexualmente dos 6 aos 11 anos de idade, por um "amigo" da família. Minha vida sexual foi estimulada e teve início muito precocemente. A partir dos 10 anos de idade, já tinha relações com vizinhas, primas, ou filhas das comadres da minha avó, porque viajava muito pro interior. Quando eu olho pra trás, não tenho ideia de como cheguei a tanto". (iJames, confidente, Diário de iJames - dados arquivais) 
Hirschman (1992) e Faber e O’Guinn (1989) comentaram sobre os limites que consumidores compulsivos e não compulsivos impõem a si próprios. Os usuários estabelecem limites para que tenham a sensação de autocontrole, como não consumir álcool dentro de casa para não influenciar negativamente os filhos, ou somente consumir às sextas-feiras na presença de amigos. Quando esses limites são ultrapassados, a sensação é de perda do autocontrole, que poderá gerar consequências como depressão e pensamento suicida.

Para os consumidores de pornografia on-line, não pareceu gerar, em regra, problemas financeiros e por isso os limites impostos parecem ser quanto ao estilo de pornografia e à realização das fantasias. O termo "fantasiar", utilizado por todos os membros da comunidade, significa "imaginar uma cena sexual com determinada pessoa, animal ou objeto". Essas fantasias vão desde "froteurismo" (desejo de encostar as genitálias em terceiros sem consentimento da parte abusada) até pedofilia, zoofilia e incesto. Broda (23 anos, solteiro) percebeu que passou do limite do consumo de pornografia quando teve interesse sexual por um animal doméstico; Arqueiro de Jesus relatou que estava em um transporte público lotado e teve o desejo impulsivo de "tarar as minas", mas que conseguiu manter o controle.

Em muitos casos, as situações limites parecem ajudar o indivíduo a rever seus comportamentos, aumentar a consciência sobre a compulsão e buscar o fórum on-line para pedir ajuda. Foi assim com Rodion Romanovich (35 anos, casado), que relata que sua "ficha caiu" há três anos, quando o consumo de pornografia passou a ser por "mais de cinco horas ao dia" e estava começando a afetar o casamento "ao ponto de colocá-lo em risco". 
Tanto na netnografia, quanto nas entrevistas, não foram encontrados relatos de inclinação a agressão sexual, mas na literatura há estudos (MALAMUTH ET AL, 2000) que apontam correlação entre compulsão por pornografia e propensão a agressão sexual.

Os limites impostos pelo próprio consumidor, uma vez transgredidos, podem evoluir para pensamentos suicidas. Um padrão observado, é que, no caso da pornografia, a depressão está constantemente associada ao pensamento suicida. Nem todos que relatam sentirem-se depressivos desenvolvem pensamento suicida, mas todos que pensam em terminar com a vida estão também depressivos. Hirschman entende que há um processo até esse ponto e que parece ser semelhante ao que foi encontrado na comunidade: "Na medida que os usuários estabelecem limites para o consumo e falham no autocontrole, suas vidas se desintegram. O indivíduo tem sensação de completa falta de controle e instabilidade emocional que o leva ao desespero e a desesperança. Esses sentimentos levam os dependentes a buscar o suicídio como a única forma de solucionar o dilema” (p. 168).

Não parecem exceções os casos de consumidores que chegam a esse grau de desenvolvimento da compulsão, nem parece ser restrito a uma faixa etária ou a estado civil. Dos 15 entrevistados, quatro relataram ter pensamento suicida: Peter Parker (20 anos, solteiro), Vegas05 (25 anos, namorando), Zorro Selvagem (39 anos, solteiro) e Edy (33 anos, casado). No fórum, os casos tem significativa recorrência.

O relato de Vegas05 (25 anos, namorando) mostra desenvolvimento do consumo de pornografia desde a infância, com família desestruturada, até depressão e pensamento suicida. Sua infância é relatada como período de traumas. “A primeira 
memória que eu tenho da minha vida é meu pai colocando a arma na boca da minha mãe e quebrando os dentes dela" e abandono dos pais. "Eu fui criado sem amor de mãe e pai, fui criado sozinho". O primeiro contato com pornografia foi aos 10 anos de idade, coincidindo com quadro de depressão causado pela morte de seu. Todas as compulsões relatadas por Vegas05 o levaram a "potencializar" a depressão que tinha: “Tentei me matar. Acordava em hospital de tanto tomar remédio. Não era por conta da pornografia, mas por todas as coisas que eu vivia. Eu acho que a pornografia potencializa isso". A consciência sobre a compulsão por pornografia on-line, diferentemente da compulsão a drogas e outros comportamentos compulsivos, só ocorreu há poucos meses, quando encontrou o fórum e começou a pedir ajuda.

\subsubsection{Categorias emergentes}

Há categorias e temas que parecem ser próprios do consumo compulsivo de pornografia on-line porque estão diretamente relacionados à sexualidade - a objetificação da mulher, a infidelidade virtual, a perda do senso de masculinidade e distúrbios sexuais. Ainda que os três primeiros possam ser considerados como distúrbios sexuais, decidi trata-los separadamente, posto que muitos membros do grupo apresentam uma consequência e outra não; por exemplo, um que reconhece tratar mulheres como objeto pode não ter problema com a autoestima, enquanto que outro, que tem disfunção erétil (distúrbio sexual), pode relacionar-se bem com mulheres.

Outras consequências pouco mencionadas, como tendência de comportamento criminoso (tendência ao estupro ou a abuso sexual) e adultério, embora sejam apresentadas na literatura (SCHNEIDER, 2000; BECHARA et al., 
2003; BAUSERMAN, 2006), não foram considerados neste estudo, por não terem sido citados com regularidade nos diários do fórum ou nas entrevistas.

Há outros efeitos que não partem da dimensão sexual, mas das vidas social e profissional do indivíduo, como a procrastinação na execução de tarefas diárias simples e efeitos na vida escolar, que parecem ter relação com a pornografia, e não foram, portanto, contemplados no estudo de Hirschman.

Identificada como consequência provável do consumo excessivo de pornografia on-line, a objetificação da mulher, segundo os membros da comunidade entrevistados, está associada a fantasiar ou imaginar mulheres regularmente, a dificuldades em começar ou manter um relacionamento, a problemas no casamento e a baixa autoestima. Os termos "objetificar" ou "olhar a mulher como objeto" são formas de expressar um tipo de comportamento constante daqueles consumidores de pornografia, que consideram a mulher como um objeto para obter satisfação sexual, tratando-as como algo a ser consumido (SCHNEIDER, 2007).

Como parece estar associada à dessensibilização do cérebro (KUHN; GALLINAT, 2014), a objetificação ocorre com quase todos os membros que se declaram compulsivos em pornografia on-line, independentemente da idade ou situação de relacionamento. A gradação de "objetificar uma mulher” em cada caso é diferente. Zorro Selvagem (39 anos, solteiro) relata que começou a consumir pornografia on-line aos 11 anos de idade, mas aos 21 passou a perceber algumas consequências da compulsão, ao "ver as mulheres como animais" e a "transar com prostitutas com bastante regularidade". Essa consequência afetou sua capacidade de iniciar relacionamentos: 
"Eu sempre estava insatisfeito, né, cara? O cérebro ficava com aquele jogo de dopamina, sendo enganado pela pornografia. Então, eu não tinha muito estímulo para ir conhecer mulher. Conversar e desenvolver o relacionamento de forma natural. Era tudo artificial. Então, eu chegava e pegava uma grana e gastava com prostituta".

Diferente de todos os demais relatantes, Vegas05 desde os 14 anos paga para consumir pornografia on-line, utilizando cartão de crédito de sua mãe. Todos os estímulos, segundo ele, serviam para aliviar as emoções negativas, lembranças e traumas de infância: "eu despejo minha bipolaridade em comida, sexo, compras, pornografia etc". Dos 16 aos 19 anos, frequentou prostíbulos e toda namorada era usada de objeto para satisfazer desejos alimentados por tantos vídeos que assistia.

As redes sociais podem facilitar a objetificação por serem impulsionadas por sensualidade e consideradas como softcore porn (BAUMGARTNER et al., 2012; BEYENS; EGGERMONT, 2014). Para Leonidas (18 anos, solteiro), não há como fazer reboot se não tiver atitudes radicais contra as fantasias, porque softcore porn também pode levá-lo a novas recaídas. "Decidi largar a pornografia e a masturbação junto com as redes sociais, que eu sabia que não estavam me fazendo bem. Eu não uso Facebook nem Instagram. Eu parei de usar o YouTube também. Hoje eu uso esse tempo para ler um livro.”. Bart (23 anos, solteiro) percebe da mesma forma a dificuldade de fazer reboot sem se abster do contato com as redes sociais. "Eu já percebi que não dá para fazer reboot se ficar inserido no Instagram. Às vezes é pior que site pornô. É absurda a quantidade de apelo sexual que tem na rede social". Costa86 (23 anos, namorando) explica que as redes sociais são gatilhos que levam a buscar pornografia hardcore: "Eu tô no Facebook e vejo uma imagem de uma mulher de biquini; isso automaticamente se converte em desejo. A partir do 
desejo, eu começo a mentalizar ela despida. Daí dá vontade de ir para o Chrome e jogar lá: 'site de pornografia'”.

Para os consumidores entrevistados que têm namorada ou são casados, suas parceiras tendem a associar o consumo de pornografia à infidelidade virtual (HERTLEIN; PIERCY, 2012), consequência que parece própria deste tipo de estímulo, não relatada em estudos sobre outras formas de compulsão. Edy (33 anos, casado) explica que a esposa tentou por várias vezes jogar fora suas revistas de conteúdo adulto, porque "ficava muito brava. Ela falava que eu estava trocando por revistas e tudo mais". O problema ficou ainda maior, segundo Edy, quando começou a querer "desenvolver as fantasias que via no filme", e então "tudo passou a não ter mais graça".

Taylor e Jackson (2015), que investigaram uma comunidade norteamericana de consumidores compulsivos de pornografia on-line, consideram que a raiz de toda motivação para abster-se do estímulo visual está no resgate da masculinidade inata, que fora perdida por conta dos vários anos de consumo. Os participantes do fórum relatam que a masturbação diante de estímulos artificiais "são uma ameaça aos relacionamentos sexuais reais e à masculinidade do indivíduo" (TAYLOR; JACKSON, 2018, p. 635). Simon Lindgren (2010) coletou comentários e interações dos fãs de pornografia em sites de sexo explícito e mostrou como, em comunidades on-line, há tendência nos consumidores homogeneizarem suas opiniões acerca de um assunto. Assim, quando muitos entendem que a pornografia pode levar à perda do senso de masculinidade (como ocorre com os membros da comunidade NoFap), outros tantos que entram na comunidade tendem a seguir essas mesmas avaliações (TAYLOR; JACKSON, 2018). 
Na comunidade que estudei, a perda do senso de masculinidade é notada em muitos diários, como sinônimo de "baixa autoestima em relação às mulheres". Bart (22 anos, solteiro) reconheceu que o consumo excessivo de pornografia afetou o seu "senso de masculinidade" quando passou a fazer o reboot, pois o efeito a curto prazo da abstinência, segundo relata, foi passar a se "sentir muito mais másculo. Me sentia muito mais homem e isso foi expresso em resultados" e contou casos em que não havia mais o sentimento de inferioridade e a baixa autoestima em situações quando precisava relacionar-se com mulheres em conversas. Bart não soube dizer se a melhora se deu apenas por causa do reboot ou se foi resultado da mudança psicológica nos poucos dias de afastamento da pornografia.

Menções a distúrbios sexuais foram bastante recorrentes, tanto nas entrevistas quanto na participação no fórum. A disfunção erétil, reconhecida como potencial consequência do consumo de pornografia on-line (MIALON et al., 2012; O'SULLIVAN et al., 2014; VOON et al., 2014), tem suas raízes, segundo os participantes do fórum, na mente do indivíduo (HEIDELBAUGH, 2015), quase sempre associada à baixa autoestima. Outros distúrbios foram frequentemente RELATADOS, como o HOCD, que parece ser consequência do aumento da tolerância - usuários buscam estímulos diferentes para manter os níveis de prazer e ereção. Bart (23 anos, solteiro) explica que, "assim como todo jovem começa assistindo homem e mulher", ele passou, depois de um tempo, a querer somente conteúdo transexual, porque o sexo entre homem e mulher "não dava prazer algum" e para ele esta etapa foi o "fundo do poço". Esses casos têm tanta ou mais incidência no fórum que os indivíduos que chegam a ter pensamento suicida. 
Hirschman não chegou a considerar as consequências dos estímulos químicos ou comportamentais na vida profissional ou nos estudos. Contudo, para os consumidores compulsivos de pornografia on-line que estudei, há relação direta, sobretudo quanto à procrastinação na execução de tarefas simples (KAFKA, 2000; WRIGHT; RANDALL, 2012). Bart (22 anos, solteiro) passou a perceber a influência negativa do consumo nos estudos quando fez reboot porque sua "mente começou a funcionar muito melhor" e não havia mais tanto problema com esquecimento ou na execução das tarefas no trabalho: "Eu costumo dizer que é uma função inversa: à medida que vai subindo meu reboot a minha procrastinação vai diminuindo. São vetores inversos, digamos assim”. Broda (23 anos, solteiro) se detém ao problema da procrastinação no estudo porque ainda não teve experiência profissional:

\footnotetext{
"Tinha situações que eu tinha que apresentar um trabalho e o trabalho tinha que ficar pronto em duas horas e eu não conseguia. Ou então eu tinha uma prova importante no dia seguinte, eu deixava de estudar pra ficar consumindo. Isso acontecia várias vezes. Isso afetou meu senso de responsabilidade com as tarefas".
}

O Quadro 6 sumariza os antecedentes e as consequências encontradas nos relatos dos diários com que interagi ao longo de aproximadamente nove meses (maio/2019 a fevereiro/2020), na comunidade Como Parar, e como essas mesmas categorias estavam presentes nas entrevistas realizadas. Para cada categoria ou subitem de categoria indicam-se estudos encontrados na literatura sobre o tema do consumo compulsivo de pornografia on-line. 
Quadro 6 - Categorias com a bibliografia respectiva

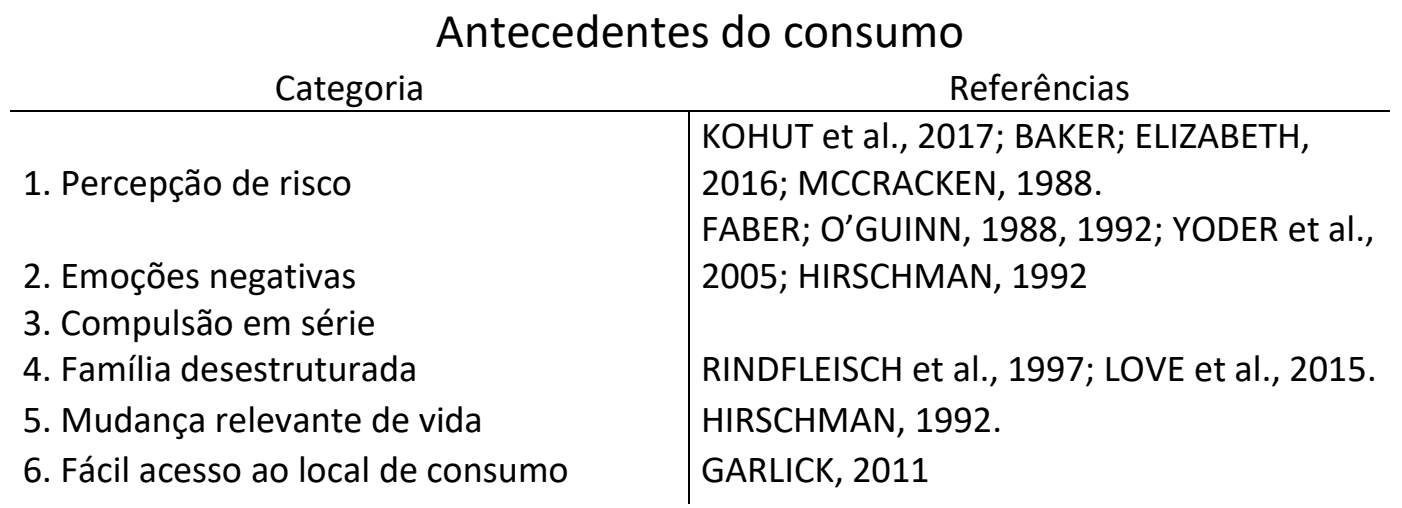

\section{Consequências percebidas}

Categoria

Referência

1. Percepção da compulsão e recaídas

1.1 Abstinência e Recaídas

1.2 Uso continuado, apesar de problemas

1.3 Desejo persistente

\section{Objetificação da mulher}

2.1 Procurar prostitutas

BLAIS-LECOURS et al., 2016; HIRSCHMAN, 1992; GRUBBS et al., 2018, 2018; HALD; MALAMUTH, 2008.

2.2 Múltiplas parceiras sexuais

LAQUEUR, 2003; ARIELY; LOWESTEIN, 2010; PRAUSE; PFAUS, 2015; IWEN, 2015;

3. Queda relevante da autoestima

3.1 Insegurança com as mulheres

3.2 Problemas interpessoais

3.3 Perda do senso de "masculinidade" PETER; VALKENBURG, 2007

4. Problemas pessoais e profissionais

4.1 Viver vida dupla

CAVAGLION, 2009; TAYLOR; JACKSON, 2018; BECHARA et al, 2003; WONG et al., 2014; TYLKA, 2015; SCHNEIDER, 2003

4.2 Redução do interesse na parceira

YAMOAH; DEI, 2015;

SCHNEIDER, 2000

PERRY, 2016; ARIELY; LOWESTEIN, 2010;

MANNING, 2006; REID et al., 2010;

WRIGHT, 2013

4.3 Dificuldade de gerenciar a própria vida

DORAN; PRICE, 2014; WITTWER; SENKBEIL, 4.4 Procrastinação no estudo e no trabalho 2008; HERTLEIN; PIERCY, 2008; WRIGHT; RANDALL, 2012

\section{Distúrbios sexuais}

KUHN; GALLINAT, 2014; MIALON et al.,

5.1 Dessensibilização e Sensibilização 2012; O'SULLIVAN et al., 2014; VOON et al.,

5.2 Dificuldade em manter ereção

5.3 Desejos estranhos 2014; PARK et al., 2016; HALD;

5.4 Crise de identidade MALAMUTH, 2013; SEIGFRIED-SPELLAR; ROGERS, 2013; NEIL; MALAMUTH, 2000

\section{Depressão e pensamento suicida} LEVIN et al,. 2012; COOPER et al., 2000; KO et al, 2014; IWEN, 2015; KAFKA, 2000 


\section{Conclusão}

Este trabalho propôs-se a investigar antecedentes e consequências do consumo compulsivo de pornografia on-line, na perspectiva de consumidores compulsivos que participam da comunidade "Como Parar" em busca de ajuda para deixar o consumo. A interpretação de suas histórias reforça evidências de que se trata de nova forma de consumo compulsivo, com particularidades que o diferenciam de outras formas apresentadas na literatura do Comportamento do Consumidor.

Assim como outras compulsões, quem desenvolve a compulsão em pornografia parece adaptar-se a estímulos oferecidos desde a mais tenra idade, por parentes ou de forma acidental. Esse padrão, quase unânime entre os casos aqui estudados, corrobora a teoria de aprendizagem (DAVISON; NEALE, 1986; HOCH; LOWESTEIN, 1991) que considera a formação da compulsão através de respostas afetivas que criam o comportamento por meio de processo "negativo-positivonegativo" (SARANEVA; SAAKSJARVI, 2008).

Os impactos do consumo compulsivo no núcleo familiar podem sofrer pequenas alterações quando comparado a outras formas de consumo compulsivo. Os consumidores aqui estudados relataram serem considerados como infiéis por suas esposas ou namoradas, por acessarem conteúdo pornográfico constantemente e pela consequente perda do interesse na relação do casal.

Os consumos compulsivos em série, discutidos por Hirschman (1992) e por Faber et al. (1987) e por Pêssoa (2016), são formas de consumo em diferentes domínios. Enquanto a compra compulsiva envolve compras exageradas utilizando 
cartões de crédito em shoppings ou em websites, a compulsão alimentar ocorre no consumo exagerado de alimentos. Neste estudo, consumidores relataram prevalência de diferentes formas de consumo compulsivo no mesmo domínio (virtual), como jogos on-line e muitas horas diárias de internet.

Consequências negativas do consumo compulsivo de pornografia on-line, como o comportamento parafílico (distúrbio psíquico que se caracteriza por práticas sexuais não convencionais, rejeitadas socialmente, como inclinação a assistir conteúdo sobre pedofilia e zoofilia - MICHAELIS, 2020), também foram bastante recorrentes e são temas de estudo em diferentes áreas do conhecimento e desperta interesse na mídia. Outras consequências relacionadas a distúrbios sexuais, como o HOCD e impotência sexual, contribuem para o interesse de estudiosos do comportamento do consumidor e para diversas teorias que relacionam o consumo compulsivo a traços da personalidade, envolvendo efeitos sobre a autoestima e a força de vontade.

Como a pornografia on-line parece afetar a sexualidade, muitos dos consumidores compulsivos aqui estudados declararam recorrem a prostitutas como forma de regular a autoestima e para usufruir das experiências que desejam. Embora cheguem a considerar que "objetificam" as mulheres que procuram, ignoram a possibilidade de desenvolver compulsão pelo consumo de sexo. Enquanto a primeira consequência possa ser desenvolvida através da quantidade de vezes que buscam o prazer pago, a segunda parece ser desenvolvida pela visão distorcida de transformar a mulher em um simples objeto de prazer, um tipo de posse temporária.

A "perda da masculinidade", que emergiu do estudo, merece especial atenção, pois parece intimamente ligada ao que Hirschman (1992) relacionou a 
construção e desconstrução do self pelo consumo compulsivo. No consumo compulsivo de pornografia on-line, parece que alguns participantes do estudo, que nasceram em ambientes familiares instáveis, construíram sua identidade de forma incompleta, inadequada ou inautêntica. Essa lacuna deixada pela deformação familiar passa a ser uma pré-disposição para a compulsão em pornografia on-line. Na mesma linha de Taylor e Jackson (2018) e de Cavaglion (2009), neste estudo foi possível perceber que a pornografia exerce influência no indivíduo que gera insegurança em relações com mulheres, consequência tanto da baixa autoestima quanto do receio de não oferecerem à parceira a atenção por ela ansiada. A abstenção da masturbação compulsiva, buscada pelos consumidores da comunidade Como Parar, quase sempre está orientada à esperança de se livrar dos distúrbios sexuais e poder recuperar a autoestima, ou, utilizando a expressão empregada por eles, "recuperar a masculinidade perdida".

Casos que continuam evoluindo sem que o usuário possa impor freios levam à depressão e a pensamentos suicidas, reconhecidos como consequências naturais do consumo compulsivo em diversos estudos, mas, que quando são causados pelo consumo de pornografia on-line, ganham novos contornos, uma vez que os sinais de sua evolução no tempo não são tão claros como ocorre em outras compulsões: a compra compulsiva ou o comportamento de apostar em jogos de azar criam endividamento; a compulsão alimentar leva à obesidade; e a bulimia leva ao emagrecimento doentio e até à morte por inanição. O consumo de pornografia online, assim como ocorre com o consumo compulsivo de jogos on-line, por ser apoiada exclusivamente em estímulos visuais, não apresenta consequências perceptíveis sobre a saúde física e não apresenta sinais evidentes para pessoas que residam sob o mesmo teto, evoluindo silenciosamente. 
Os consumidores que relataram professar a fé cristã (autodeclarados católicos ou protestantes) tiveram mais resistência ao primeiro contato com o consumo da pornografia on-line ou que resistiam mais a recaídas, porque a religião opera como uma espécie de freio moral ou de consciência. Os indivíduos deixam de consumir não porque entendem que faz mal, mas porque assim sentem-se ofendendo a Deus. Este achado está em consonância com estudos que colocam a religiosidade como variável moderadora do consumo de pornografia on-line quanto maior a religiosidade, menor a probabilidade de consumir regularmente (PERRY, 2017). Pesquisas no campo de marketing ainda não foram realizadas, buscando replicar esses estudos dentro da perspectiva do comportamento de consumo, e podem ser relevantes no Brasil, onde a população é majoritariamente cristã.

Como a imersão netnográfica concentrou-se em jovens de 20 a 29 anos, foram muitos os relatos de indivíduos que percebem a influência negativa da pornografia em sua vida escolar. No entanto, a literatura de consumo compulsivo só tratou até hoje de efeitos da compra compulsiva entre jovens como uma forma de autoafirmação, não como algo que atinja diretamente a autoestima ou afete dedicação aos, ou aproveitamento nos estudos (LIU; LAIRD, 2008).

Aplicativos como Instagram, Facebook, Youtube e o novo Tik Tok são dirigidos a relações interpessoais por meio de textos, fotos e vídeos. A influência que ocorre dessas redes em quem consome compulsivamente pornografia, é a manutenção da compulsão dado que, segundo os participantes da comunidade, são repletos de softporn. Isso leva a um paradoxo: se a prevalência do consumo de pornografia on-line obedece a mesma proporção das demais compulsões, cerca de 
5\% dos indivíduos que consomem tornam-se compulsivos, há muito mais consumidores compulsivos do que podemos imaginar e sua grande maioria deve utilizar com frequência tais redes sociais. Seria como pedir ao consumidor compulsivo de álcool que largue a compulsão indo todos os dias ao bar, ou ao apostador compulsivo que frequente bingos enquanto tenta recuperar-se. Este achado, se aprofundado com experimentos aplicados a situações reais, empregando escalas que testem níveis de compulsão em pornografia (como a como a Problematic Pornography Use Scale - PPUC), combinando com frequência de uso de redes sociais, poderá fornecer novos insights para a discussão.

Por fim, este estudo também pode contribuir para melhor entendimento do que pode ser considerado como pornografia. O consumo de filmes pornográficos encontra resistência quando eles são exibidos de forma pública, ou em família ou entre amigos. No entanto, filmes e séries exibidos na televisão, no cinema ou em canais digitais (como Netflix), que contém cenas de sexo explícito, não são criticados da mesma forma. Enquanto os primeiros são vistos como reprováveis e sua exibição pode ensejar sansões legais, o segundo é aceitável para a sociedade. Portanto, o consumidor compulsivo de pornografia on-line pode estar mais suscetível a estímulos apresentados por produtos como as séries de tv, aliviando sua consciência por considerar que o que está fazendo não é algo reprovável, do que ao ser exposto de forma explícita ao visitar sites de pornografia com restrições para menores de 18 anos. 


\section{Limitações do estudo}

Esta tese descreve antecedentes e consequências de um tipo de consumo compulsivo não inserido no estudo pioneiro de Elizabeth Hirschman (1992). No entanto, as interpretações estão limitadas aos consumidores com quem pude interagir e absorver seu modo de ver o mundo, principalmente por ter sido um consumidor compulsivo de pornografia on-line.

A limitação quanto ao público que interagi pode-se concluir o mesmo que a autora: "talvez a maior ironia do vício seja que, quando você está imerso nele, pode senti-lo, mas não pode vê-lo. Depois que você sai do vício, você pode vê-lo, mas não o sente com a intensidade que você sentiu na outra vez." (HIRSCHMAN, 1992, p. 177).

Uma vez que os consumidores compulsivos estudados participam do fórum e interagem com outras pessoas também dependentes, sua capacidade de perceber efeitos da compulsão, a capacidade de descrever o que sentem e as influências que essa avaliação sofre podem ter causado vieses nas interpretações feitas. Além disso, pode haver diferença entre o que é expresso por um consumidor que está afastado por algum tempo da pornografia on-line e o que é dito por aquele que está descrevendo o que ocorreu no mesmo dia. 


\section{Sugestões para estudos futuros}

Estudos futuros podem buscar consumidores de pornografia on-line que a vêem como positiva, ou que a consomem regularmente e não se vêem como dependentes. Podem também identificar algum grupo formado por mulheres que se autodeclaram consumidoras compulsivas e avaliar antecedentes e consequências do consumo para um público bem diverso.

Na comunidade como parar, o grupo de homossexuais é bastante reduzido e pouco se sabe sobre suas percepções com relação ao consumo compulsivo de pornografia. Estudos relacionados a comunidades de homossexuais que sejam consumidores compulsivos de pornografia on-line podem também contribuir para alargar o entendimento sobre o tema.

A faixa etária acima de 40 anos também não foi estudada aqui e pode revelar interessantes diferenças no padrão de consumo, em antecedentes e em consequências percebidas. Esse grupo cresceu e se tornou adulto sem a opção online da pornografia, que somente surgiu quando seu cérebro estava totalmente formado e sua vida sexual provavelmente iniciada. Homens e mulheres acima de 60 anos poderão trazer contribuições valiosas sobre a mudança cultural e o crescimento do consumo de pornografia, uma vez que formam a geração dos anos 60 que sofreu impacto direto da revolução sexual” (GARLICK, 2011).

A amplitude e a dificuldade de se mensurar o mercado consumidor de pornografia on-line dificulta o aparecimento de estudos que possam calcular a prevalência (proporção de consumidores compulsivos). A começar pela limitação do que é e não é pornografia, depois em encontrar indivíduos que A consomem, de 
forma regular, compulsiva ou recreativamente, dispostos a participar de surveys ou de entrevistas que podem ser constrangedoras. No entanto, faz-se necessário mensurar, ainda que em grupos menores, a incidência desse tipo de comportamento, que atinge milhões de pessoas em todo o mundo.

Por fim, estudos futuros utilizando métodos diferentes, incluindo abordagens quantitativas, poderão explorar melhor cada uma das consequências aqui levantadas, por meio de escalas já conhecidas (i.e. PPUC) ou especialmente desenvolvidas e testadas.

Também não foram encontrados artigos que investiguem o efeito das redes sociais sobre a pornografia leve (softcore), embora houvesse considerável quantidade de relatos a respeito disso. Na comunidade onde foi feita a netnografia, é quase unânime o entendimento de que o uso do Facebook ou do Instagram durante o reboot não é recomendável porque frequentemente conduz a recaídas. 


\section{Referências Bibliográficas}

ACHTZIGER, A.; HUBERT, M.; KENNING, P.; RAAB, G.; REISCH, L. Debt out of control: The links between self-control, compulsive buying, and real debts. Journal of Economic Psychology, v. 49, pp. 141-149, 2015. APA. American Psychiatric Association. DSM-V: Manual diagnóstico e estatístico de transtornos mentais. Artmed Editora, 2014.

ARIELY, D.; G. LOEWENSTEIN. The heat of the moment: The effect of sexualarousal on sexual decision-making. Journal of Behavioral Decision Making, v. 19, pp. 87-98, 2010.

ARNOLD, S. J.; FISCHER, E. Hermeneutics and consumer research. Journal of Consumer Research, v. 21(1), pp. 55-70, 1994.

ASAM. American Society for Addiction Medicine. Disponível em: < https://www.asam.org/Quality-Science/publications/magazine/public-policystatements/2019/10/21/short-definition-of-addiction>. Acessado em 10/04/2020.

ASATO, M. R.; TERWILLIGER, R.; WOO, J.; LUNA, B. White matter development in adolescence: A DTI study. Cerebral Cortex, v. 20, pp. 2122-2131, 2010.

ATKINS JR, R. G.; HAWDON, J. E. Religiosity and participation in mutualaid support groups for addiction. Journal of substance abuse treatment, v. 33(3), pp. 321-331, 2007.

BAKER, K. Online pornography-Should schools be teaching young people about the risks? An exploration of the views of young people and teaching professionals. Sex Education, v. 16, n. 2, pp. 213-228, 2016.

BAKER, T.B.; PIPER, M.E.; MCCARTHY, D.E.; MAJESKIE, M.R.; FIORE, M.C. Addiction motivation reformulated: an affective processing model of negative reinforcement. Psychological review, v. 111, pp. 33-51, 2004.

BAUMAN, K. E.; ENNETT, S. T. On the importance of peer influence for adolescent drug use: Commonly neglected considerations. Addiction, 91(2), 185-198, 1996.

BAUMEISTER, R. F.; BRATSLAVSKY, E.; FINKENAUER, C.; VOHS, K. D. Bad is stronger than good. Review of general psychology, v. 5, n. 4, pp. 323-370, 2001. 
BAUMGARTNER, S.E.; SUMTER, S.R.; PETER, J.; VALKENBURG, P. Identifying teens at risk: developmental pathways of online and offline sexual risk behavior. Pediatrics, v. 130, pp.1489-1496, 2012.

BAUSERMAN, R. Sexual aggression and pornography: A review of correlational research. Basic and Applied Social Psychology, v. 18, pp. 405-27, 2006.

BECHARA, A.; BERTOLINO, M. V.; CASAB, A.; MUNARRIZ, R.; GOLDSTEIN, I.; MORIN, A.; FREDOTOVICH, N. Romantic partners use of pornography: Its significance for women. Journal of Sex \& Marital Therapy, v. 29(1), pp. 1-14, 2003.

BERRIDGE, K. C. Is Addiction a Brain Disease? Neuroethics, v. 10, pp. 29-33, 2017.

BEYENS, I.; EGGERMONT, S. Putting young children in front of the television: Antecedents and outcomes of parents' use of television as a babysitter. Communication Quarterly, 62(1), 57-74, 2014.

BEYENS, I.; VANDENBOSCH, L.; EGGERMONT, S. Early adolescent boys' exposure to Internet pornography: Relationships to pubertal timing, sensation seeking, and academic performance. The Journal of Early Adolescence, v. 35(8), pp. 1045-1068, 2015.

BLACK, D. W.; KEHRBERG, L. L.; FLUMERFELT, D. L.; SCHLOSSER, S. $S$. Characteristics of 36 subjects reporting compulsive sexual behavior. The American Journal of Psychiatry, v. 154(2), pp. 243-249, 1997.

BLAIS-LECOURS, S.; VAILLANCOURT-MOREL, M. P.; SABOURIN, S.; GODBOUT, N. Cyberpornography: Time use, perceived addiction, sexual functioning, and sexual satisfaction. Cyberpsychology, Behavior, and Social Networking, v. 19(11), pp. 649-655, 2016.

BOELLSTORFF, T. Coming of age in second life: an anthropologist explores the virtually human. New Jersey, Princeton University Press, 2015.

BOIES, S. C. University students' uses of and recreations to online sexual information and entertainment: Links to online and offline sexual behavior. Canadian Journal of Human Sexuality, v. 11, pp. 77-89, 2002.

BOSTWICK, J. M.; BUCCI, J. A. Internet sex addiction treated with naltrexone. Mayo Clinic Proceedings, v. 83, pp. 226-230, 2008.

BÖTHE, B.; TÓTH-KIRÁLY, I.; OROSZ, G. Clarifying the links among online gaming, internet use, drinking motives, and online pornography use. Games for health journal, v. 4(2), pp. 107-112, 2015.

BOWLER JR, G. M. Netnography: A method specifically designed to study cultures and communities online. The Qualitative Report, v. 15(5), pp. 1270, 2010.

BRAND, M.; LAIER, C.; PAWLIKOWSKI, M.; SCHÄCHTLE, U.; SCHÖLER, T.; ALTSTÖTTER-GLEICH, C. Watching pornographic pictures on the 
Internet: Role of sexual arousal ratings and psychological-psychiatric symptoms for using Internet sex sites excessively. Cyberpsychology, Behavior, and Social Networking, v. 14, pp. 371-377, 2011.

BRAND, M.; YOUNG, K. S.; LAIER, C.; WÖLFLING, K.; POTENZA, M. N. Integrating psychological and neurobiological considerations regarding the development and maintenance of specific Internet-use disorders: An Interaction of Person-Affect-Cognition-Execution (I-PACE) model. Neuroscience and Biobehavioral Reviews, v. 71, pp. 252-266, 2016

BRAUN-COURVILLE, D. K.; ROJAS, M. Exposure to sexually explicit web sites and adolescent sexual attitudes and behaviors. Journal of adolescent health, v. 45(2), pp. 156-162, 2009.

BRIDGES, A. J.; MOROKOFF, P. J. Sexual media use and relational satisfaction in heterosexual couples. Personal Relationships, v. 18, pp. 562-585, 2011.

BRISTER, P.; BRISTER, D. The Vicious Circle Phenomenon: Our Battle for Self-control: how to Win the War. Diadem Pub, 1987.

CARROLL, J. S.; PADILLA-WALKER, L. M.; NELSON, L. J.; OLSON, C. D.; MCNAMARA, B. C.; MADSEN, S. D. Generation XXX: Pornography Acceptance and Use among Emerging Adults. Journal of Adolescent Research, v. 23, pp. 6-30, 2008.

CASTRO-CALVO, J.; BALLESTER-ARNAL, R.; POTENZA, M. N., KING, D. L.; BILLIEUX, J. Does "forced abstinence" from gaming lead to pornography use? Insight from the April 2018 crash of Fortnite's servers. Journal of behavioral addictions, 7(3), 501-502, 2018.

CAVAGLION, G. Cyber-porn dependence: voices of distress in an Italian internet self-help community. International journal of mental health and addiction, v. 7(2), pp. 295-310, 2009.

CHANG, W. L.; LU, L. C.; CHANG, K. Y. Mediating effect of buying motives between physical vanity and online compulsive buying. African

Journal of Business Management, v. 5(8), pp. 3289-3296, 2011.

CHERRIER, H.; PONNOR, T. A study of hoarding behavior and attachment to material possessions. Qualitative Market Research: An International Journal, v. 13(1), pp. 8-23, 2010.

CHERRIER, H.; PONNOR, T. A study of hoarding behavior and attachment to material possessions. Qualitative Market Research: An International Journal, v. 13(1), pp. 8-23, 2010.

CHILDRESS, A.R.; EHRMAN, R.N.; WANG, Z.; LI, Y.; SCIORTINO, N.; HAKUN, J.; JENS, W.; SUH, J.; LISTERUD, J.; MARQUEZ, K.; FRANKLIN, T.; LANGLEBEN, D.; DETRE, J.; O'BRIEN, C.P. Prelude to Passion: Limbic Activation by "Unseen” Drug and Sexual Cues. PLoS ONE 3, 2008.

CHOU-GREEN, J. M.; HOLSCHER, T. D.; DALLMAN, M. F.; AKANA, S. F. Compulsive behavior in the $5-\mathrm{HT} 2 \mathrm{C}$ receptor knockout mouse.

Physiology \& behavior, v. 78(4-5), pp. 641-649, 2003. 
COLEMAN, E.J.; WALTER O. B. Masturbation As a Means of Achieving Sexual Health. New York : Haworth, 2002.

COMO PARAR, Disponível em: comoparar.com, acessado em 10/05/2019.

COOPER, A. Sexuality and the Internet: Surfing into the new millennium. Cyber Psychology and Behavior, v. 1, pp. 181-187, 1998.

COOPER, A.; DELMONICO, D. L.; BURG, R. Cybersex user, abusers, and compulsives. Sexual Addiction and Compulsivity, v. 7, pp. 5-29, 2000.

COOPER, A.; PUTNAM, D. E.; PLANCHON, L. A.; BOIES, S. C. Online sexual compulsivity. Sexual Addiction and Compulsivity, v. 6, pp. 79104, 1999.

COOPERSMITH, J. Does your mother know what you really do? The changing image and nature of computer-based pornography. History and Technology, v. 22(1), pp. 1-25, 2006.

COSKUNER-BALLI, GOKCEN.; THOMPSON, C.J. The Status Costs of Subordinate Cultural Capital: At-Home Fathers' Collective Pursuit of Cultural Legitimacy Through Capitalizing Consumption Practices. Journal of Consumer Research, v.40, pp. 19-41, 2013.

CRESWELL, J.W. Research Design: Qualitative, Quantitative, and Mixed Methods Approaches. California: SAGE, 2ed, 2003.

CUMINALE, N. Claro enigma. Revista Veja, 84-91, 2016.

DARRAT, A. A., DARRAT, M. A.; AMYX, D. How impulse buying influences compulsive buying: The central role of consumer anxiety and escapism. Journal of Retailing and Consumer Services, v. 31, pp. 103108, 2016

D'ASTOUS, A. An inquiry into the compulsive side of "normal" consumers. Journal of consumer policy, v. 13(1), pp. 15-31, 1990.

DAVISON, G. C.; NEALE, J. M. Abnormal Psychology, New York: Wiley, 1986.

DAVISON, K. P.; PENNEBAKER, J. W.; DICKERSON, S. S. Who talks? The social psychology of illness support groups. American Psychologist, v. 55(2), pp. 205, 2000.

DAYMON, C., \& HOLLOWAY, I. Qualitative research methods in public relations and marketing communications. Abingdon, UK: Routledge, 2011.

DE BRUIJN, P.; BURRIE, I.; VAN WEL, F. A risky boundary: Unwanted sexual behavior among youth. Journal of sexual aggression, v. 12(2), pp. 81-96, 2006.

DE OLIVEIRA, T; IKEDA, A.; DA COSTA, R. (2004). Compra compulsiva e a influência do cartão de crédito. RAE-Revista de Administração de Empresas, v. 44(3), pp. 89-99. 
DESARBO, W. S.; EDWARDS, E. A. Typologies of compulsive buying behavior: A constrained clusterwise regression approach. Journal of consumer psychology, v. 5(3), pp. 231-262, 1996.

Diário de Pernambuco disponível em:

$<$ https://www.diariodepernambuco.com.br/noticia/viver/2015/02/justica-diminuiclassificacao-indicativa-de-em-cinquenta-tons-de-cinza-em-no-brasil.html >, acessado em 09 de fevereiro de 2015.

DITTMAR, H.; BEATTIE, J.; FRIESE, S. Objects, decision onsiderations and self-image in men's and women's impulse purchases. Acta psychologica, v. 93(1-3), pp. 187-206, 1996.

DORAN, K.; PRICE, J. Pornography and marriage. Journal of Family and Economic Issues, v. 35(4), pp. 489-498, 2014.

EDELMAN, B. Red light states: Who buys online adult entertainment? Journal of Economic Perspectives, v. 23, pp. 209-220, 2009.

ELDERS, M J. Sex for Health and Pleasure Throughout a Lifetime: Findings from the National Survey of Sexual Health and Behavior. Center for Sexual Health Promotion, Indiana University, v. 7, pp. 248-249, 2010.

ELHAI, J. D.; DVORAK, R. D.; LEVINE, J. C.; HALL, B. J. Problematic smartphone use: A conceptual overview and systematic review of relations with anxiety and depression psychopathology. Journal of affective disorders, v. 207, pp. 251-259, 2017.

ELLIOTT, R. Addictive consumption: Function and fragmentation in postmodernity. Journal of consumer policy, v. 17(2), pp. 159-179, 1994. ESTADÃO disponível em <https://emais.estadao.com.br/noticias/tv, bbb-20-mp-ripedira-inquerito-apos-conversa-sobre-zoofilia,70003185388>, acessado em 19 maio de 2020

FABER, R. J., \& O'GUINN, T. C. A clinical screener for compulsive buying. Journal of consumer Research, 19(3), 459-469, 1992.

FABER, R. J., \& O'GUINN, T. C. Compulsive consumption and credit abuse. Journal of Consumer Policy, 11(1), 97-109, 1988

FABER, R. J., O'GUINN, T. C.; KRYCH, R. Compulsive consumption. ACR North American Advances, 1987.

FABER, R. J.; CHRISTENSON, G. A.; DE ZWAAN, M.; MITCHELL, J. Two forms of compulsive consumption: Comorbidity of compulsive buying and binge eating. Journal of Consumer research, v. 22(3), pp. 296-304, 1995

FABER, R. J.; O'GUINN, T. C.; KRYCH, R. Compulsive Consumption. Advances in Consumer Research, v. 14, pp. 132-135, 1987.

FISHER, W. A.; BARAK, A. Internet pornography: A social psychological perspective on Internet sexuality. Journal of Sex Research, v. 38(4), pp. 312-323, 2001.

FRADD, M. The porn myth: Exposing the reality behind the fantasy of pornography. Ignatius Press, 2017. 
GADAMER, H. G. Truth and Method. Glen-Dopel, London: Sheed and Ward, 1975.

GADAMER, H. G. Truth and method. New York: Continuum, 1989.

GARLICK, S. A new sexual revolution? Critical theory, pornography, and the Internet. Canadian Review of Sociology, v. 48, p. 221-239, 2011.

GEORGIADIS, J.R.; KRINGELBACH, M.L. The human sexual response cycle: Brain imaging evidence linking sex to other pleasures. Progress in Neurobiology, v. 98, pp. 49-81, 2012

GOULDING, C.; SAREN, M.; LINDRIDGE, A. Reading the body at von Hagen's 'body worlds'. Annals of Tourism Research, v. 40, p. 306-330, 2013.

GRANT, J.E.; BREWER, J.A.; POTENZA, M.N. The neurobiology of substance and behavioral addictions. CNS Spectrums, v. 11, pp. 924-930, 2006.

GRIFFITHS, M. Does Internet and computer "addiction" exist? Some case study evidence. CyberPsychology \& Behavior, v. 3, pp. 211-218, 2000.

GROSS, J. J. Emotion regulation: conceptual and empirical foundations. Nova lorque: The Guilford Press, 2014.

GROUGIOU, V., \& PETTIGREW, S. Seniors' attitudes to voicing complaints: a qualitative study. Journal of marketing Management, 25(910), 987-1001, 2009.

GROUGIOU, V.; MOSCHIS, G.; KAPOUTSIS, I. Compulsive buying: the role of earlier-in-life events and experiences. Journal of Consumer Marketing, 2015.

GROV, C.; GILLESPIE, B.; ROYCE, T.; LEVER, J. Perceived consequences of casual online sexual activities on heterosexual relationships: A U.S. online survey. Archives of Sexual Behavior, v. 40, p. 429-439, 2011.

GRUBBS, J. B.; STAUNER, N.; EXLINE, J. J.; PARGAMENT, K. I.; LINDBERG, M. J. Perceived addiction to Internet pornography and psychological distress: Examining relationships concurrently and over time.

Psychology of Addictive Behaviors, v. 29(4), pp. 1056, 2015.

GRUBBS, J. B.; WILT, J. A.; EXLINE, J. J.; PARGAMENT, K. I. Predicting pornography use over time: Does self-reported "addiction" matter?. Addictive behaviors, v. 82, pp. 57-64, 2018.

GUO, Z.; CAI, Y. Exploring the antecedents of compulsive buying tendency among adolescents in China and Thailand: A consumer socialization perspective. African Journal of Business Management, v. 5(24), pp. 10198-10209, 2011.

HALD, G. M. Gender differences in pornography consumption among young heterosexual Danish adults. Archives of Sexual Behavior, v. 35, pp. 577585, 2006. 
HALD, G. M.; MALAMUTH, N. M. Self-perceived effects of pornography consumption. Archives of Sexual Behavior, v. 37, pp. 614-625, 2008.

HALD, G. M.; MALAMUTH, N. N.; LANGE, T. Pornography and sexist attitudes among heterosexuals. Journal of Communication, v. 63.4, p. 638-660, 2013.

HASIN, D. S.; O'BRIEN, C. P.; AURIACOMBE, M.; BORGES, G.; BUCHOLZ, K.; BUDNEY, A.; SCHUCKIT, M. DSM-5 criteria for substance use disorders: recommendations and rationale. American Journal of Psychiatry, v. 170(8), pp. 834-851, 2013.

HASSAY, D. N., \& SMITH, M. C. Compulsive buying: An examination of the consumption motive. Psychology \& Marketing, 13(8), 741-752, 1996. HEIDELBAUGH, J. J.; STELWAGON, M.; MILLER, S. A.; SHEA, E. P.; CHEY, W. D. The spectrum of constipation-predominant irritable bowel syndrome and chronic idiopathic constipation: US survey assessing symptoms, care seeking, and disease burden. The American journal of gastroenterology, v. 110, pp. 580, 2015.

HEIDELBAUGH, J.J. Management of Erectile Dysfunction-American Family Physician. Available online: http://www.aafp.org/afp/2010/0201/p305.html (accessed on 17 November 2015).

HERTLEIN, K. M.; PIERCY, F. P. Essential elements of Internet infidelity treatment. Journal of Marital and Family Therapy, 38, 257-270, 2012.

HERTLEIN, KATHERINE M., AND FRED P. PIERCY. Therapists' assessment and treatment of Internet infidelity cases. Journal of Marital and Family Therapy, v. 34.4, pp. 481-497, 2008.

HILTON, D.L. Pornography addiction - A supranormal stimulus considered in the context of neuroplasticity. Socioaffective Neuroscience Psychology, v. 3, 2013.

HING, N.; LAMONT, M.; VITARTAS, P.; FINK, E. Sports bettors' responses to sports-embedded gambling promotions: Implications for compulsive consumption. Journal of Business Research, v. 68(10), pp. 2057-2066, 2015.

HIRSCHMAN, E. C. The consciousness of addiction: Toward a general theory of compulsive consumption. Journal of Consumer Research, $v$. 19(2), pp. 155-179, 1992.

HIRSCHMAN, E. C., \& STERN, B. B. The roles of emotion in consumer research. ACR North American Advances, 1999.

HOCH, S. J.; LOEWENSTEIN, G. F. "Time-inconsistent Preferences and Consumer Self-Control," Journal of Consumer Research, v. 17 (March), pp. 492-507, 1991.

HOCH, S. J; GEORGE F.; LOEWENSTEIN. "Time-inconsistent Preferences and Consumer Self-Control," Journal of Consumer Research, v. 17 (March), pp. 492-507, 1991. 
HOOK, J. N., REID, R. C., PENBERTHY, J. K., DAVIS, D. E., \& JENNINGS, D. J. Methodological review of treatments for nonparaphilic hypersexual behavior. Journal of sex \& marital therapy, v. 40(4), pp. 294-308, 2014.

HOOKWAY, N. Entering the blogosphere': some strategies for using blogs in social research. Qualitative research, v. 8, n. 1, p. 91-113, 2008.

HOYER, W. D.; MACINNIS, D. J.; PIETERS, R. Customer behavior. Boston, Houghton Mifflin Company, 2001.

HUNT, L. Introduction: Obscenity and the Origins of Modernity. The Invention of Pornography: Obscenity and the Origins of Modernity. New York: Zone Books, pp. 3-17, 1993.

IWEN, M. E. Shame, sexual addiction, and consumption in American culture. Sexuality \& Culture, v. 19(3), pp. 413-425, 2015.

JANSSEN, E.; BRANCROFT, J. The Dual-Control Model: The role of sexual inhibition \& excitation in sexual arousal and behavior. In The Psychophysiology of Sex. Indiana University Press: Bloomington, US, pp. 197-222, 2007.

JANTA, H. "Polish migrant workers in the UK hospitality industry", International Journal of Contemporary Hospitality Management, v. 23, n. 6, pp. 803-819, 2011.

JAPUTRA, A.; EKINCI, Y.; SIMKIN, L. Self-congruence, brand attachment and compulsive buying. Journal of Business Research, 99, 456-463, 2019.

JOHNSON, T.; ATTMANN, J. Compulsive buying in a product specific context: clothing. Journal of Fashion Marketing and Management: An International Journal, 2009.

JONES, E. M. Libido dominandi: sexual liberation and political control. South Bend. St. Augustine's Press, 2005.

KAFKA, M. P. The paraphilia-related disorders: A proposal for a unified classification of nonparaphilic hypersexuality disorders. Sexual Addiction \& Compulsivity: The Journal of Treatment and Prevention, v. 8(3-4), pp. 227-239, 2001.

KELLETT, S.; TOTTERDELL, P. Compulsive buying: A field study of mood variability during acquisition episodes. The Cognitive Behaviour

Therapist, v. 1, pp. 16-26, 2008.

KLEIN, V.; SCHMIDT, A. F.; Turner, D.; Briken, P. Are sex drive and hypersexuality associated with pedophilic interest and child sexual abuse in a male community sample?. PloS one, 10(7), 2015

KOHUT, T., FISHER, W. A; Campbell, L. Perceived effects of pornography on the couple relationship: Initial findings of open-ended, participantinformed, "bottom-up" research. Archives of Sexual Behavior, v. 46(2), pp. 585-602, 2017.

KOOB, G. F.; LE MOAL, M. Neurobiological mechanisms for opponent motivational processes in addiction. Philosophical Transactions of the 
Royal Society B: Biological Sciences, v. 363, n. 1507, pp. 3113-3123, 2008.

KOR, A.; ZILCHA-MANO, S.; FOGEL, Y. A.; MIKULINCER, M.; REID, R. C.; POTENZA, M. N. Psychometric development of the problematic pornography use scale. Addictive behaviors, v. 39(5), pp. 861-868, 2014.

KOUKOUNAS, E., OVER, R. Changes in the magnitude of the eyeblink startle response during habituation of sexual arousal. Behavior research and therapy, v. 38(6), pp. 573-584, 2000.

KOZINETS, R. V. Click to connect: netnography and tribal advertising. Journal of advertising research, 46(3), 279-288, 2006.

KOZINETS, R. V. Netnografia: realizando pesquisa etnográfica online. Penso Editora, 2014.

KOZINETS, R. V. Netnography. The international encyclopedia of digital communication and society, pp. 1-8, 2015.

KOZINETS, R. V. Netnography: Doing ethnographic research online. London, UK: Sage, 2010.

KRAUS, S.; ROSENBERG, $\mathrm{H}$. The pornography craving questionnaire: Psychometric properties. Archives of sexual behavior, v. 43(3), pp. 451462, 2014.

KÜHN, S; GALLINAT, J. Brain structure and functional connectivity associated with pornography consumption: the brain on porn. JAMA psychiatry, v. 71, n. 7, pp. 827-834, 2014.

KUKAR-KINNEY, M., SCHEINBAUM, A. C., \& SCHAEFERS, T. Compulsive buying in online daily deal settings: An investigation of motivations and contextual elements. Journal of business research, $v$. 69(2), pp. 691-699, 2016.

KUSS, D. J.; LOPEZ-FERNANDEZ, O. Internet addiction and problematic Internet use: A systematic review of clinical research. World journal of psychiatry, 6(1), 143, 2016.

LAIER, C., SCHULTE, F. P.; BRAND, M. Pornographic picture processing interferes with working memory performance. Journal of sex research, $v$. 50(7), pp. 642-652, 2013.

LAM, S. C.; CHAN, Z. S. L.; CHONG, A. C. Y.; WONG, W. W. C.; YE, J. Adaptation and validation of Richmond compulsive buying scale in Chinese population. Journal of behavioral addictions, v. 7(3), pp. 760769, 2018.

LANDRIPET, I.; ŠTULHOFER, A. Is Pornography Use Associated with Sexual Difficulties and Dysfunctions among Younger Heterosexual Men? The journal of sexual medicine, v. 12, pp. 1136-1139, 2015.

LAQUEUR, T. Solitary sex: A cultural history of masturbation. Zone Books, 2003.

LAUMANN, E.O.; PAIK, A.; ROSEN, R.C. Sexual dysfunction in the United States: Prevalence and predictors. JAMA, v. 281, pp. 537-544, 1999. 
LAYDEN, M. A. Pornography and violence: A new look at the research. In J. R. STONER JR; D. M. HUGHES. The social costs of pornography: A collection of papers. New Jersey, NY: Witherspoon Institute, 2010.

LEE, S. H., LENNON, S. J.,; RUDD, N. A. (2000). Compulsive consumption tendencies among television shoppers. Family and

Consumer Sciences Research Journal, 28(4), 463-488, 2000.

LEMMENS, J. S.; VALKENBURG, P. M.; GENTILE, D. A. The Internet gaming disorder scale. Psychological assessment, v. 27, n. 2, pp. 567, 2015.

LEON, G. R. Case Histories of Deviant Behavior, Boston: Allyn \& Bacon, 1984.

LEVERT, N. P. A comparison of Christian and non-Christian males, authoritarianism, and their relationship to Internet pornography addiction/compulsion. Sexual Addiction \& Compulsivity, v. 14(2), pp. 145-166, 2007.

LEVIN, M. E.; LILLIS, J.; HAYES, S. C. When is online pornography viewing problematic among college males? Examining the moderating role of experiential avoidance. Sexual Addiction \& Compulsivity, v. 19(3), pp. 168-180, 2012.

LEWIN, B. Pornography: Attitudes and use. Stockholm: The National Institute of Public Health, pp. 252-263, 1997.

LEWIN, K. Resolving social conflicts and field theory in social science. American Psychological Association, 1997.

LEWIS, M. Addiction and the brain: development, not disease. Neuroethics, v. 10, n. 1, pp. 7-18, 2017.

LINDGREN, S. Widening the glory hole: The discourse of online porn fandom, 2010. In: ATTWOOD, F. Porn.com: Making Sense of Online Pornography. New York: Peter Lang, pp. 171-185.

LIU C.; LAIRD R. Parenting, peer influence, and role model on compulsive buying tendencies of early adolescent consumers. ACR North American Advances, v. 35: pp. 1036-1038, 2008.

LÖFGREN-MÅRTENSON, L.; MÅNSSON, S. A. Lust, love, and life: A qualitative study of Swedish adolescents' perceptions and experiences with pornography. Journal of sex research, 47(6), 568-579, 2010.

LOFTUS, R. A. Disconnecting child pornography on the Internet: barriers and policy considerations. Journal of the Oxford Round Table, 2008.

LOVE, T.; LAIER, C.; BRAND, M.; HATCH, L.; HAJELA, R. Neuroscience of Internet Pornography Addiction: A Review and Update. Behavioral Sciences, v. 5, pp. 388-433, 2015.

LYKINS, A. D.; MEANA, M.; STRAUSS, G. P. Sex differences in visual attention to erotic and non-erotic stimuli. Archives of sexual behavior, $v$. 37, n. 2, pp. 219-228, 2008. 
MALAMUTH, N. M. Adding fuel to the fire"? Does exposure to nonconsenting adult or to child pornography increase risk of sexual aggression?. Aggression and violent behavior, v. 41, pp. 74-89, 2018.

MALAMUTH, N. M.; ADDISON, T.; KOSS, M. Pornography and sexual aggression: Are there reliable effects and can we understand them? Annual review of sex research, v. 11(1), pp. 26-91, 2000.

MANNING, J. C. The impact of Internet pornography on marriage and the family: A review of the research. Sexual Addiction \& Compulsivity, v. 13, pp. 131-165, 2006.

MARTIN, I.M.; KAMINS, M.A.; PIROUZ, D.M.; DAVIS, S.W.; HAWS, K.L.; MIRABITO, A.M. On the road to addiction: The facilitative and preventive roles of marketing cues. Journal of Business Research, 66(8), 12191226, 2013.

MATTEBO, M., TYDÉN, T.; HÄGGSTRÖM-NORDIN, E.; NILSSON, K. W.; LARSSON, M. Pornography consumption, sexual experiences, lifestyles, and self-rated health among male adolescents in Sweden. Journal of Developmental \& Behavioral Pediatrics, v. 34(7), pp. 460-468, 2013.

MATUSIK, S. F.; MICKEL, A. E. Embracing or embattled by converged mobile devices? Users experiences with a contemporary connectivity technology. Human Relations, v. 64(8), pp. 1001-1030, 2011.

MCCORMACK, M.; WIGNALL, L. Enjoyment, exploration and education: Understanding the consumption of pornography among young men with non-exclusive sexual orientations. Sociology, 51(5), 975-991, 2017.

MCCORMACK, M.; WIGNALL, L. Enjoyment, exploration and education: Understanding the consumption of pornography among young men with non-exclusive sexual orientations. Sociology, v. 51(5), pp. 975-991, 2007.

MCCRACKEN, G. The long interview, v. 13, Sage, 1988.

MCCRACKEN, GRANT, The Long Interview, Beverly Hills, CA: Sage, 1988 apud ARNOLD, S. J.; FISCHER, E. Hermeneutics and consumer research. Journal of Consumer Research, v. 21(1), pp. 55-70, 1994.

MCELROY, S. L.; HUDSON, J. I.; POPE, H. G.; KECK, P. E. Kleptomania: clinical characteristics and associated psychopathology. Psychological Medicine, v. 21(1), pp. 93-108, 1991.

MCNAIR, B. Striptease culture. London: Routledge, 2002.

MENDELSON, J.; NANCY M. The Addictive Personality, New York: Chelsea House, 1986.

MESTRE-BACH, G.; BLYCKER, G. R.; POTENZA, M. N. Pornography use in the setting of the COVID-19 pandemic. Journal of Behavioral Addictions, 2020.

MIALON, A.; BERCHTOLD, A.; MICHAUD, P. A.; GMEL, G.; SURIS, J. C. Sexual dysfunctions among young men: prevalence and associated factors. Journal of Adolescent Health, v. 51(1), pp. 25-31, 2012. 
MICHAELIS moderno dicionário da língua portuguesa. São Paulo: Melhoramentos. Disponível em: <http://michaelis.uol.com.br/>. Acesso em: 09 maio 2020.

MILES, M. B.; HUBERMAN, A. M. Qualitative data analysis: An expanded sourcebook. Sage, 1994.

MITCHELL, K. J.; FINKELHOR, D.; WOLAK, J. The exposure of youth to unwanted sexual material on the Internet: A national survey of risk, impact, and prevention. Youth \& Society, v. 34, n. 3, pp. 330-358, 2003.

MKONO, M. A netnographic examination of constructive authenticity in Victoria falls tourist (restaurant) experiences. International Journal of Hospitality Management, v. 31 n. 2, p. 387-394, 2012.

MORELLI, M.; BIANCHI, D.; BAIOCCO, R.; PEZZUTI, L.; CHIRUMBOLO, A. Sexting behaviors and cyber pornography addiction among adolescents: The moderating role of alcohol consumption. Sexuality Research and Social Policy, v. 14(2), pp. 113-121, 2017.

MOSCHIS, G. P. Research frontiers on the dark side of consumer behaviour: The case of materialism and compulsive buying. Journal of Marketing Management, 33(15-16), 1384-1401, 2017.

MOWEN, J. C. (2003). Minor, Michael S. Comportamento do consumidor. São Paulo: Prentice Hall, 26.

NATARAAJAN, R.; GOFF, B. G. Manifestations of compulsiveness in the consumer-marketplace domain. Psychology \& Marketing, v. 9(1), pp. 3144, 1992.

O'GUINN, T. C.; FABER, R. J. Compulsive buying: A phenomenological exploration. Journal of consumer research, v. 16, pp. 147-157, 1989.

OLEJNICZAK, D. Brain Activity in Sex Addiction Mirrors That of Drug Addiction. University of Cambridge, v.11, 2014.

OLSEN, C.M. Natural rewards, neuroplasticity, and non-drug addictions.

Neuropharmacology, v. 61, pp. 1109-1122, 2011.

OSMAN, H.; JOHNS, N.; LUGOSI, P. Commercial hospitality in destination experiences: McDonald's and tourists' consumption of space. Tourism Management, v. 42, pP. 238-247, 2014.

O'SULLIVAN, L. F., BROTTO, L. A., BYERS, E. S., MAJEROVICH, J. A., \& WUEST, J. A. Prevalence and characteristics of sexual functioning among sexually experienced middle to late adolescents. The journal of sexual medicine, v. 11(3), pp. 630-641, 2014.

OULASVIRTA, A.; RATTENBURY, T.; RAITA, E. Habits make smartphone use more pervasive. Personal and Ubiquitous Computing, v. 16(1), pp. 105-114, 2012.

OWENS, E.W.; BEHUN, R.J.; MANNING, J. C.; REID, R. C. The Impact of Internet Pornography on Adolescents: A Review of the Research. Sexual Addiction \& Compulsivity: The Journal of Treatment \& Prevention, v. 19, pp. 99-122, 2012. 
PALAN, K. M.; MORROW, P. C.; TRAPP, A.; BLACKBURN, V.

Compulsive buying behavior in college students: the mediating role of

credit card misuse. Journal of Marketing Theory and Practice, v. 19(1), pp. 81-96, 2011.

PARK, B.; WILSON, G.; BERGER, J.; CHRISTMAN, M.; REINA, B., BISHOP, F.; DOAN, A. Is Internet pornography causing sexual dysfunctions? A review with clinical reports. Behavioral Sciences, v. 6(3), pp. 17, 2016.

PARYLAK, S. L.; KOOB, G. F.; ZORRILLA, E. P. The dark side of food addiction. Physiology \& behavior, v. 104(1), pp149-156, 2011.

PAUL, B.; SHIM, J. W. Gender, sexual affect, and motivations for Internet pornography use. International Journal of Sexual Health, v. 20, pp. 87199, 2008.

PECHMAN, C.; LEVINE, L.; LOUGHLIN, S.; LESLIE, F. Impulsive and self-conscious: Adolescents' vulnerability to advertising and promotion. Journal of Public Policy and Marketing, 24, 202-221, 2005.

PEELE, S. The meaning of addiction: Compulsive experience and its interpretation. Lexington Books/DC Heath and Com, 1985.

PERRY, S. L. Does viewing pornography reduce marital quality over time? Evidence from longitudinal data. Archives of Sexual behavior, v. 46, n. 2, pp. 549-559, 2017.

PERRY, S. L. From bad to worse? Pornography consumption, spousal religiosity, gender, and marital quality. Sociological Forum, v. 31, pp. 441-464, 2016.

PESSÔA, L.; KAMLOT, D.; BARBOSA, S. C. "Compradoras compulsivas: motivações, hábitos e experiências de consumo." Revista ADM. MADE 20, pp. 36-56, 2016.

PETER, J.; VALKENBURG, P. M. Adolescents' exposure to a sexualized media environment and notions of women as sex objects. Sex Roles, v. 56, pp. 381-395, 2007.

PETER, J.; VALKENBURG, P. M. Adolescents' exposure to sexually explicit material on the Internet. Communication Research, v. 33, n. 2, pp. 178204, 2006.

PETERSEN, J.; J. HYDE. "Gender Differences in Sexual Attitudes and Behaviors: A Review of Meta-Analytic Results and Large Datasets."

Journal of Sex Research, v. 48 (2-3), pp. 149-165, 2011.

PETRY, NANCY M., AND CHARLES P. O'BRIEN. Internet gaming disorder and the DSM-5. Addiction, v. 108, n. 7, pp. 1186-1187, 2013.

PHILLIPS, J. G.; OGEIL, R. P.; BLASZCZYNSKI, A. Electronic interests and behaviors associated with gambling problems. International Journal of Mental Health and Addiction, v. 10, n. 4, pp. 585-596, 2012.

PITCHERS, K. K.; BALFOUR, M. E.; LEHMAN, M. N.; RICHTAND, N. M.; YU, L.; COOLEN, L. M. Neuroplasticity in the mesolimbic system induced 
by natural reward and subsequent reward abstinence. Biological psychiatry, v. 67, n. 9, pp. 872-879, 2010.

PIZZOL, D.; BERTOLDO, A.; FORESTA, C. Adolescents and web porn: A new era of sexuality. International journal of adolescent medicine and health, v. 28, n. 2, pp. 169-173, 2016.

POULSEN, F. O.; BUSBY, D. M.; GALOVAN, A. M. Pornography use: Who uses it and how it is associated with couple outcomes. Journal of sex research, v. 50, pp. 72-83, 2013.

PRAUSE, N.; PFAUS, J. Viewing sexual stimuli associated with greater sexual responsiveness, not erectile dysfunction. Sexual medicine, v. 3, n. 2, pp. 90-98, 2015.

PRICE, J.; PATTERSON, R.; REGNERUS, M.; WALLEY, J. How much more XXX is Generation X consuming? Evidence of changing attitudes and behaviors related to pornography since 1973. The Journal of Sex Research, v. 53, n. 1, pp. 12-20, 2016.

PRINS, J., BLANKER, M. H., BOHNEN, A. M., THOMAS, S., \& BOSCH, J. L. H. R. Prevalence of erectile dysfunction: a systematic review of population-based studies. International journal of impotence research, v. 14(6), pp. 422-432, 2002.

RAGEH, A.; MELEWAR, T. C.; WOODSIDE, A. Using netnography research method to reveal the underlying dimensions of the customer/tourist experience. Qualitative Market Research: An International Journal, 2013.

RAPPAPORT, J. Narrative studies, personal stories, and identity transformation in the mutual help context. The journal of applied behavioral science, v. 29, n. 2, p. 239-256, 1993.

REID, R. C., CARPENTER, B. N., DRAPER, E. D., \& MANNING, J. C. Exploring psychopathology, personality traits, and marital distress among women married to hypersexual men. Journal of Couple \& Relationship Therapy, v. 9(3), pp. 203-222, 2010.

REID, R. C., LI, D. S., GILLILAND, R., STEIN, J. A., \& FONG, T. Reliability, validity, and psychometric development of the Pornography Consumption Inventory in a sample of hypersexual men. Journal of Sex \& Marital Therapy, v. 37, n. 5, pp. 359-385, 2011.

RHEINGOLD, H. A slice of life in my virtual community. Global networks: Computers and international communication, pp. 57-80, 1993.

RINDFLEISCH, A., BURROUGHS, J. E.; DENTON, F. Family structure, materialism, and compulsive consumption. Journal of consumer research, 23(4), 312-325, 1997

RINDFLEISCH, A.; BURROUGHS, J. E.; DENTON, F. Family structure, materialism, and compulsive consumption. Journal of consumer research, 23(4), 312-325, 1997.

ROBERTS, J. A., GWIN, C. F.; MARTINEEZ, C. R. The influence of family structure on consumer behavior: A re-inquiry and extension of Rindfleisch 
et al.(1997) in Mexico. Journal of Marketing Theory and Practice, v. 12(1), pp. 61-79, 2004.

ROBINSON, T. E.; BERRIDGE, K. C. The incentive sensitization theory of addiction: some current issues. Philosophical Transactions of the Royal Society B: Biological Sciences, v. 363, n. 1507, pp. 3137-3146, 2008.

ROBINSON, T.E.; K.C. BERRIDGE. (2001). Incentive-sensitization and addiction. Addiction, v. 96(1), pp. 103-114.

ROBINSON, T.E.; K.C. BERRIDGE. The neural basis of drug craving: an incentive-sensitization theory of addiction. Brain Research Reviews, v. 18(3), pp. 247-291, 1993.

ROOK, D. W. The buying impulse. Journal of consumer research, 14(2), 189-199, 1987.

ROOK, D. W.; HOCH, S. J. Consuming impulses. ACR North American

Advances, 1995.

ROSS, M.W.; MANSSON, S. A.; DANEBACK, K. Prevalence, severity, and correlates of problematic sexual Internet use in Swedish men and women.

Archives of Sexual Behavior, v. 41, pp. 459-466, 2012.

RUPP, H. A.; WALLEN, K. Sex differences in response to visual sexual stimuli: A review. Archives of sexual behavior, v. 37(2), pp. 206-218, 2008.

RUSSELL, G. Bulimia nervosa: an ominous variant of anorexia nervosa.

Psychological medicine, 9(3), 429-448, 1979.

RUVIO, A.; SOMER, E.; RINDFLEISCH, A. When bad gets worse: The amplifying effect of materialism on traumatic stress and maladaptive consumption. Journal of the Academy of Marketing Science, v. 42(1), pp. 90-101, 2014.

RYE, B. J.; UNDERHILL, A. Contraceptive Context, Conservatism, Sexual Liberalism, and Gender-Role Attitudes as Predictors of Abortion Attitudes. Women's Reproductive Health, v. 6, n. 1, pp. 34-51, 2019.

SARANEVA, A.; SÄÄKSJÄRVI, M. Young compulsive buyers and the emotional roller-coaster in shopping. Young Consumers, 2008.

SCARABOTO, D.; FISCHER, E. Frustrated fashionistas: An institutional theory perspective on consumer quests for greater choice in mainstream markets. Journal of Consumer Research, v. 39, n. 6, pp. 1234-1257, 2013.

SCARABOTO, D.; ZILLES, F. P.; RODRIGUEZ, J. B.; KNY, M. A. Pequenos luxos, grandes prazeres-significados do consumo e valores dos consumidores de joalheria e vestuário de luxo. Anais do II Encontro de Marketing da ANPAD, pp. 03-05, 2006.

SCHERHORN, G. The addictive trait in buying behaviour. Journal of Consumer policy, v. 13(1), pp. 33-51, 1990.

SCHLOSSER, S.; BLACK, D. W.; REPERTINGER, S.; FREET, D. Compulsive buying: Demography, phenomenology, and comorbidity in 46 subjects. General hospital psychiatry, v. 16(3), pp. 205-212, 1994. 
SCHNEIDER, J. P. Effects of cybersex addiction on the family: Results of a survey. Sexual Addiction and Compulsivity, v. 7, pp. 31-58, 2000.

SCHNEIDER, J.P. The impact of compulsive cybersex behaviors on the family. Sexual and Relationship Therapy, v. 18, pp. 329-354, 2003.

SCHOUTEN, J. W. Selves in Transition: Symbolic Consumption in Personal Rites of Passage and Identity Reconstruction. Journal of Consumer Research, v. 17, pp. 412-425, 1991.

SCHUSTER, M.; DA VEIGA DIAS, V.; BATTISTELLA, L. F. Validação e investigação da relação entre comportamento compulsivo de compra e consumismo. Revista de Administração FACES Journal, v. 15(3), pp. 51-68, 2016.

SCHWARTZ, M. F.; SOUTHERN, S. Compulsive cybersex: The new tearoom. Sexual Addiction \& Compulsivity: The Journal of Treatment and Prevention, v. 7, n. 1-2, pp. 127-144, 2000.

SEIGFRIED-SPELLAR, K. C.; ROGERS, M. K. Does deviant pornography use follow a Guttman-like progression? Computers in Human Behavior, v. 29(5), pp. 1997-2003, 2013.

SHAPIRO, B. Porn generation: How social liberalism is corrupting our future. Simon and Schuster, 2013.

SHETH, J.; MITTAL, B.; NEWMAN, B. Comportamento do cliente. São Paulo: Atlas, 2001.

SHOAF, F. R.; SCATTONE, J.; MORRIN, M.; MAHESWARAN, D. Gender differences in adolescent compulsive consumption. ACR North American Advances, 1995.

SHORT, M. B.; BLACK, L.; SMITH, A. H.; WETTERNECK, C. T.; WELLS, D. E. A review of Internet pornography use research: Methodology and content from the past 10 years. Cyberpsychology, Behavior, and Social Networking, v. 15, n. 1, pp. 13-23, 2012.

SKINNER, B. F. Ciência e comportamento humano. São Paulo, SP: Martins Fontes, 2003.

SNEATH, J. Z.; LACEY, R.; KENNETT-HENSEL, P. A. Coping with a natural disaster: Losses, emotions, and impulsive and compulsive buying.

Marketing letters, v. 20(1), pp. 45-60, 2009.

SOLOMON, M. R. O Comportamento do consumidor: comprando, possuindo e sendo. Porto Alegre: Bookman, 2011.

STACK, S.; WASSERMAN, I.; KERN, R. Adult social bonds and use of internet pornography. Social science quarterly, v. 85, pp. 75-88, 2004.

STEELE, V. R.; STALEY, C.; FONG, T.; PRAUSE, N. Sexual desire, not hypersexuality, is related to neurophysiological responses elicited by sexual images. Socioaffective neuroscience \& psychology, 3(1), 2014.

SVEDIN, C. G., ÅKERMAN, I., PRIEBE, G. Frequent users of pornography. A population based epidemiological study of Swedish male adolescents. Journal of adolescence, v. 34(4), pp. 779-788, 2011. 
TAYLOR, K.; JACKSON, S. 'I want that power back': Discourses of masculinity within an online pornography abstinence forum. Sexualities, v. 21(4), pp. 621-639, 2018.

TAYLOR, S; BOGDAN, R. Introduction to Qualitative Research Methods: The Search for Meanings. New York: John Wiley, 1984.

TECHTUDO acessado em 23/06/2020:

https://www.techtudo.com.br/noticias/2020/05/31 percent-dos-brasileirosja-praticaram-sexting-na-quarentena-diz-pesquisa.ghtml

THANH, T. V.; KIROVA, V. Wine tourism experience: A netnography study. Journal of Business Research, v. 83, pp. 30-37, 2018.

THOMPSON, C. J.; LOCANDER, W. B.; HOWARD, R. POLIO. The lived meaning of free choice: An existential-pherfomenological description of everyday consumer experiences of contemporary married women. Journal of Consumer Research, v. 17(3), pp. 346-361, 1990.

THOMPSON, C. J.; LOCANDER, W. B.; POLLIO, H. R. Putting consumer experience back into consumer research: The philosophy and method of existential-phenomenology. Journal of Consumer Research, 16, 2, 133146, 1989.

THOMPSON, C. J.; POLLIO, H. R.; LOCANDER, W. B. The spoken and the unspoken: a hermeneutic approach to understanding the cultural viewpoints that underlie consumers' expressed meanings. Journal of Consumer research, v. 21(3), pp. 432-452, 1994.

TOLEDANO, Margalit. Emergent methods: Using netnography in public relations research. Public relations review, v. 43, n. 3, pp. 597-604, 2017.

TRACY, K.; WALLACE, S. P. Benefits of peer support groups in the treatment of addiction. Substance abuse and rehabilitation, v. 7, pp. 143, 2016.

TRÆEEN, B., SØRHEIM-NIELSEN, T.; STIGUM, H. Use of pornography in traditional media and on the internet in Norway. Journal of Sex Research, 43, 245-254, 2006.

TRÆEEN, B., SPITZNOGLE, K., \& BEVERFJORD, A. Attitudes and use of pornography in the Norwegian population 2002. Journal of Sex Research, v. 41(2), pp. 193-200, 2004.

TRAUTMANN-ATTMANN, J; JOHNSON, T.W. Compulsive Consumption Behaviors: Investigating Relationships among Binge Eating, Compulsive Clothing Buying and Fashion Orientation. International. Journal of Consumer Studies, v. 33: pp. 267-273, 2009.

TYLKA, T. L. No harm in looking, right? Men's pornography consumption, body image, and well-being. Psychology of Men \& Masculinity, v. 16(1), pp. 97-107, 2015.

TYLKA, T. L.; KROON VAN DIEST, A. M. You Looking at Her "Hot" Body May Not be "Cool" for Me: Integrating Male Partners' Pornography Use into 
Objectification Theory for Women. Psychology of Women Quarterly, v. 39(1), pp. 67-84, 2015.

UNODC. United Nations Office on Drugs and Crime. World Drug Report, p.174, 2016.

VAILLANCOURT-MOREL, M. P.; GODBOUT, N.; LABADIE, C.; RUNTZ, M., LUSSIER, Y.; SABOURIN, S. Avoidant and compulsive sexual behaviors in male and female survivors of childhood sexual abuse. Child Abuse \& Neglect, 40, 48-59, 2015.

VALENCE, G.; D'ASTOUS, A.; FORTIER, L. Compulsive buying: concept and measurement. Journal of Consumer Policy, v. 11, p. 419-433, 1988

VALENCE, G.; D'ASTOUS, A.; FORTIER, L. Compulsive buying: Concept and measurement. Journal of consumer policy, v. 11(4), pp. 419-433, 1988.

VALLERAND, R. J.; PELLETIER, L. G.; KOESTNER, R. Reflections on selfdetermination theory. Canadian Psychology, v. 49(3), pp. 257, 2008.

VAN DEN EIJNDEN, R. J.; SPIJKERMAN, R.; VERMULST, A. A.; VAN ROOIJ, T. J.; ENGELS, R. C. Compulsive Internet use among adolescents: Bidirectional parent-child relationships. Journal of abnormal child psychology, v. 38, n. 1, p. 77-89, 2010.

VANDONINCK, S.; D'HAENENS, L.; DONOSO, V. Digital literacy of Flemish youth: How do they handle online content risks? Communications, v. 35, pp. 397-416, 2010.

VEZINA P., LEYTON M. Conditioned cues and the expression of stimulant sensitization in animals and humans. Neuropharmacology, v. 56, pp. 160168, 2009.

VOLKOW, N. D.; BALER, R. D.; COMPTON, W. M.; WEISS, S. R. Adverse health effects of marijuana use. New England Journal of Medicine, v. 370, n. 23, p. 2219-2227, 2014.

VOLKOW, N. D.; BALER, R. D.; GOLDSTEIN, R. Z. Addiction: pulling at the neural threads of social behaviors. Neuron, v. 69(4), pp. 599-602, 2011.

VOON, V.; MOLE, T.B.; BANCA, P.; PORTER, L.; MORRIS, L.; MITCHELL, S.; LAPA, T.R.; KARR, J.; HARRISON, N.A.; POTENZA, M.N.; IRVINE, M. Neural correlates of sexual cue reactivity in individuals with and without compulsive sexual behaviors. PloS one, v. 9, n. 7, 2014.

VROMAN, K.; KOVACICH, J. Computer-mediated interdisciplinary teams: Theory and reality. Journal of Interprofessional Care, v. 16(2), pp. 159170, 2002.

WALKER, B. A., OLSON, J. C. Means-end chains: Connecting products with self. Journal of business research, v. 22(2), pp. 111-118, 1991. WANG, Y.. Addiction by design: Using netnography for user experiences in female online gambling game. International Journal of HumanComputer Interaction, v. 34, n. 8, pp. 774-785, 2018.

WEAVER, J. B.; WEAVER, S. S.; MAYS, D., HOPKINS, G. L.; KANNENBERG,W.; MCBRIDE, D. Mental-and physical-health indicators 
and sexually explicit media use behavior by adults. The journal of sexual medicine, v. 8, n. 3, pp. 764-772, 2011.

WIEGMAN, R. Unmaking: Men and masculinity in feminist theory. Masculinity studies and feminist theory, v. 35, 2002.

WILLOUGHBY, B. J.; CARROLL, J. S.; BUSBY, D. M.; BROWN, C. C. Differences in pornography use among couples: Associations with satisfaction, stability, and relationship processes. Archives of sexual behavior, v. 45, n. 1, pp. 145-158, 2016.

WILSON, G. Your Brain on Porn: Internet pornography and the emerging science of addiction. Margate: Commonwealth Publishing, 2014.

WITTMANN, B.C.; BUNZECK, N.; DOLAN, R.J.; DÜZEL, E. Anticipation of novelty recruits reward system and hippocampus while promoting recollection. Neurolmage, v. 38, pp. 194-202, 2007.

WITTWER, J.; SENKBEIL, M. Is students' computer use at home related to their mathematical performance at school? Computers \& Education, v. 50, pp. 1558-1571, 2008.

WOLAK, J.; MITCHELL, K.; FINKELHOR, D. Unwanted and wanted exposure to online pornography in a national sample of youth Internet users.

Pediatrics, v. 119, pp. 247-257, 2007.

WOLCOTT, H.F., Transforming Qualitative Data: Description, Analysis, and Interpretation. Sage: Thousand Oaks, CA, 1994.

WORKMAN, L.; PAPER, D. Compulsive buying: A theoretical framework.

The Journal of Business Inquiry, v. 9(1), pp. 89-126, 2010.

WRIGHT, P. J.; RANDALL, A. K. Internet pornography exposure and risky sexual behavior among adult males in the United States. Computers in Human Behavior, v. 28, pp. 1410-1416, 2012.

YAMOAH, E. E.; DEI, D. Effects of pornography on Christian marriage: An empirical review. Global Journal of Arts Humanities and Social Sciences, v. 3, n. 1, pp. 1-13, 2015.

YBARRA, M. L.; MITCHELL, K. J. Exposure to Internet pornography among children and adolescents: A national survey. Cyberpsychology \& behavior, v. 8, n. 5, pp. 473-486, 2005.

YODER, Vincent Cyrus; VIRDEN III, THOMAS B.; AMIN, Kiran. Internet pornography and loneliness: An association? Sexual addiction \& compulsivity, v. 12, n. 1, pp. 19-44, 2005.

YOUN, S.; FABER, R. Impulse buying: its relations to personality traits and cues. Advances in Consumer Research, v. 27, 2000. pp.179-186.

YOUNG, K. S. (2008). Internet sex addiction risk factors, stages of development, and treatment. American Behavioral Scientist, v. 52, pp. 2137.

YOUNG, K. S. Internet addiction: The emergence of a new clinical disorder. Cyberpsychology \& behavior, v. 1(3), pp. 237-244, 1998. 
YUODELIS-FLORES, Christine; RIES, Richard K. Addiction and Suicide: A Review. FOCUS, A Journal of the American Psychiatric Association, v. 17, n. 2, pp. 193-199, 2019.

ZILLMANN, D.; BRYANT, J. Shifting preferences in pornography consumption. Communication Research, v. 13(4), pp. 560-578, 1986.

\section{Anexos}

Anexo 1: Post de entrada na comunidade

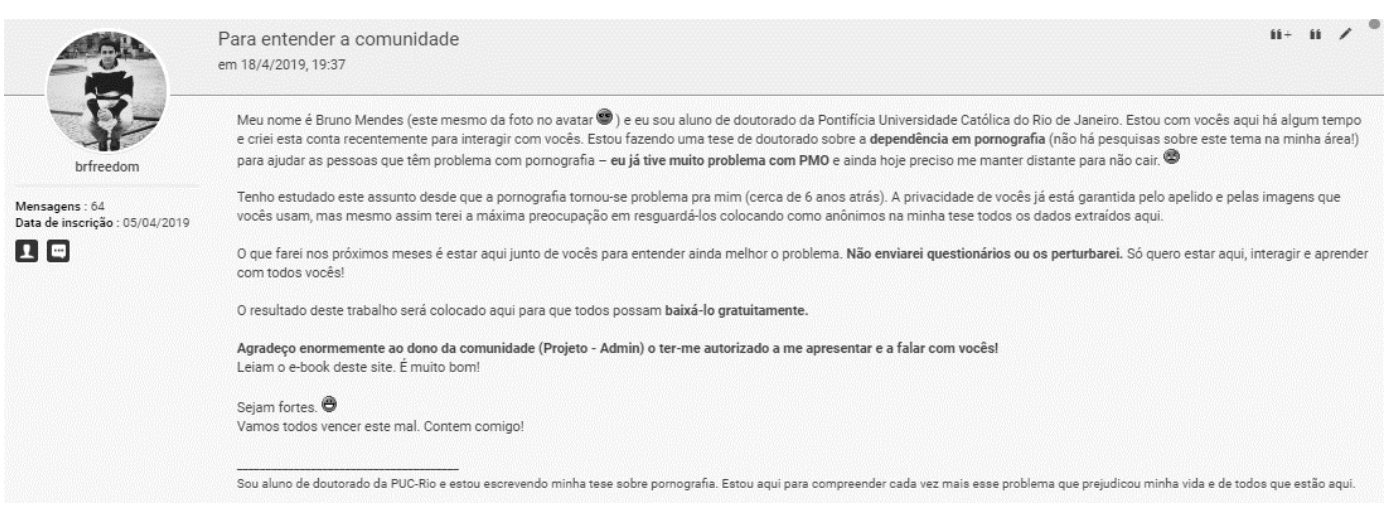

Transcrição do post:

"Título: Para entender a comunidade

Meu nome é Bruno Mendes (este mesmo da foto no avatar 워).

Sou estudante de doutorado da Pontifícia Universidade Católica do Rio de Janeiro. Estou fazendo uma tese sobre a dependência em pornografia on-line (não há pesquisas sobre este tema na minha área) para ajudar as pessoas que têm problema com pornografia - eu já tive muito problema com isso e ainda hoje preciso me manter distante para não voltar a consumir. $\odot$

Tenho estudado este assunto desde que a pornografia tornou-se problema pra mim. Faço parte da comunidade norte-americana "NoFap" desde 2016 e aqui estou por algum tempo também.

Agora me sinto preparado para entender os comentários e os posts desta comunidade através da perspectiva científica. A privacidade já está garantida pelo apelido e pelas imagens que vocês usam, mas mesmo assim terei a máxima preocupação em resguardá-los na minha tese a partir dos dados extraídos aqui.

O que farei nos próximos meses é estar aqui junto de vocês para entender ainda melhor o problema. Não enviarei questionários ou os perturbarei. Só quero estar aqui, interagir e aprender com todos vocês.

O resultado deste trabalho será disponibilizado para que todos possam baixá-lo gratuitamente. 
Agradeço enormemente ao dono da comunidade, Projeto-Admin, o ter-me autorizado a falar com vocês!"

Anexo 2: Anúncio global.

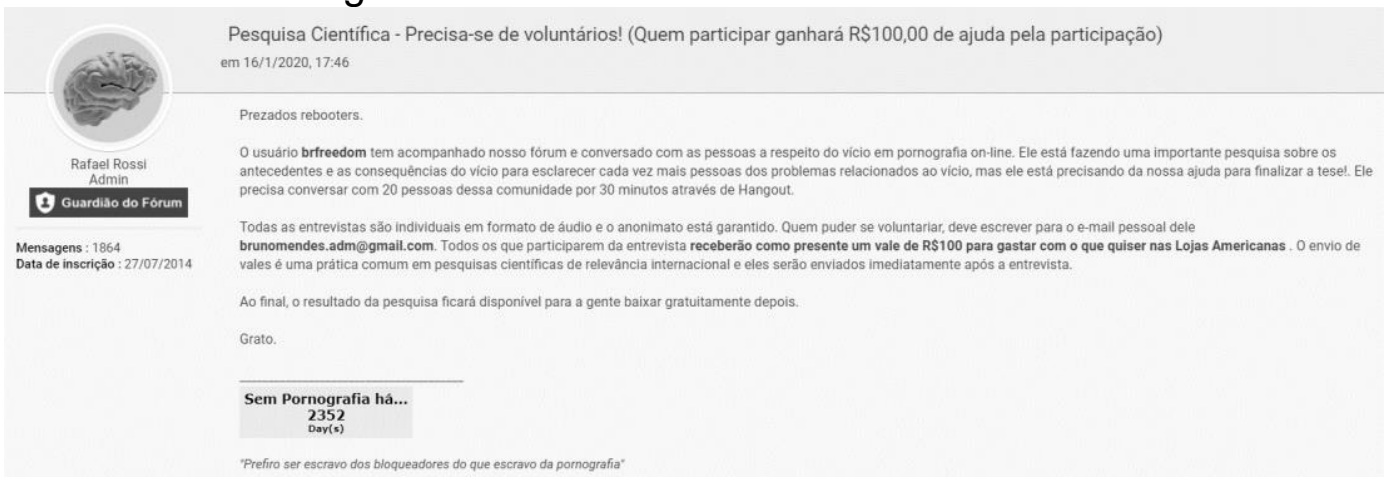

Link: http://www.comoparar.com/t10036-pesquisa-cientifica-precisa-se-devoluntarios-quem-participar-ganhara-r10000-de-ajuda-pela-participacao\#272547

\section{Anexo 3: Aprovação do comitê de ética da PUC-Rio para aplicação das entrevistas neste estudo.}

$$
\text { Pontifícia Universidade C Católica } \text { Do Rio de Janeiro }
$$

COMITÊ DE ÉTICA EM PESQUISA DA PUC-Rio - CEPq / PUC-Rio Parecer $N^{\circ}$ 84/2019 - (Protocolo 83/2019)

O Comitê de Ética em Pesquisa da PUC-Rio denominado, CEPq - PUC-Rio, vinculado à ViceReitoria para Assuntos Acadêmicos, é responsável pela avaliação e acompanhamento de todas as pesquisas envolvendo seres humanos, a ele encaminhadas, observando os fundamentos éticos e cientificos pertinentes.

Identificação:

Título: "A Droga Invisivel: diferenças e semelhanças entre o consumo compulsivo em pornografia on-line e as demais dependências químicas e comportamentais" (Departamento de Administração da PUC-Rio).

Autora: Bruno Farias Mendes (Doutorando do Departamento de Administração da PUC-Rio).

Orientadora: Luis Fernando Hor-meyll (Professor do Departamento de Administraçāo da PUC-Rio).

Apresentação: Pesquisa netnográfica que tem como objetivo investigar aspectos relacionados ao uso compulsivo e abusivo de pornografia no ambiente online. O estudo será realizado com membros de uma comunidade online anônima. Utilizará entrevista em profundidade com pessoas do sexo masculino de 20 a 29 anos de idade. Seguirá o método de pesquisa de Kozinets (2006).

Aspectos éticos: $\mathrm{O}$ projeto e o Termo de Consentimento Livre e Esclarecido apresentados estão de acordo com os principios e valores do Marco Referencial, Estatuto e Regimento da Universidade no que se refere às responsabilidades de seu corpo docente e discente. O Termo expõe com clareza os objetivos da pesquisa e os procedimentos a serem seguidos. Garante o sigilo e a confidencialidade dos dados coletados. Informa sobre a possibilidade de interrupção na pesquisa sem aplicaçăo de qualquer penalidade ou constrangimento.

Parecer: Aprovado

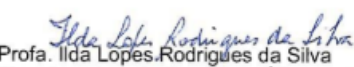

Coordenadora do Comitê de Ética em Pesquisa - PUC-Rio 


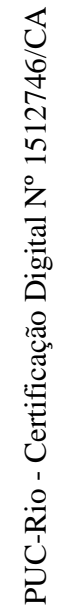

